\title{
Flying more efficiently: Joint impacts of fuel prices, capital costs and fleet size on airline fleet fuel economy
}

\section{CCEP Working Paper 1810}

\section{November 2018}

\section{Zsuzsanna Csereklyei}

School of Economics, Finance and Marketing, RMIT University

\section{David I Stern}

Crawford School of Public Policy, The Australian National University

\begin{abstract}
We investigate the factors that affect airlines' choice of fleet fuel economy using planelevel data for 1267 airlines in 174 countries. Larger and newer planes are usually more fuel- efficient. Controlling for the effect of aircraft size and age, we find that the technically achievable fleet fuel economy improves with the size of airlines and the price of fuel and worsens with higher capital costs. The elasticity of fuel economy with respect to the price of fuel is between -0.07 and -0.13 . We find evidence for regional differences in fleet fuel economy that are attributable to the adoption of distinct groups of technologies.
\end{abstract}




\title{
Keywords:
}

Energy efficiency; air transport

\author{
JEL Classification: \\ D22; L93; O14; Q40
}

\section{Acknowledgements:}

We thank the Australian Research Council for funding under Discovery Project (DP160100756) "Energy Efficiency Innovation, Diffusion and the Rebound Effect." We thank Alexander Koduah and Bishal Chalise for research assistance and seminar participants at the Arndt-Corden Department of Economics at the Australian National University and the Department of Economics at the University of Sydney for useful comments.

\section{Suggested Citation:}

Csereklyei, Z. and Stern, DI. (2018), Flying more efficiently: joint impacts of fuel prices, capital costs and fleet size on airline fleet fuel economy, CCEP Working Paper 1810, November 2018, Crawford School of Public Policy, The Australian National University.

\section{Address for Correspondence:}

Zsuzsanna Csereklyei

School of Economics, Finance and Marketing

RMIT University

B80, 445 Swanston Street

Melbourne VIC 3000, Australia

Phone: +61399251518

E-mail: zsuzsanna.csereklyei@rmit.edu.au

The Crawford School of Public Policy is the Australian National University's public policy school, serving and influencing Australia, Asia and the Pacific through advanced policy research, graduate and executive education, and policy impact.

The Centre for Climate Economics \& Policy is an organized research unit at the Crawford School of Public Policy, The Australian National University. The working paper series is intended to facilitate academic and policy discussion, and the views expressed in working papers are those of the authors. Contact for the Centre: Prof Frank Jotzo, frank.jotzo@anu.edu.au 


\section{Introduction}

The International Energy Agency (IEA) expects that, up to 2040, reductions in energy intensity will contribute $42 \%$ of the reduction in greenhouse gas emissions relative to business as usual required to achieve the goal of limiting climate change to a $2^{\circ} \mathrm{C}$ increase in temperature (IEA, 2016). The IEA expects the majority of this improvement in energy intensity to come from improvements in the energy efficiency of energy services (IEA, 2014: 285-286). On the other hand, the mechanisms enabling the geographical spread of such energy saving technological improvements have not been sufficiently investigated (Barretto and Kemp 2008; Verdolini and Galeotti, 2011). The airline industry is perhaps unique in the availability of global data on installed equipment at the individual machine (and firm) level together with information on model energy efficiency. Though carbon emissions from air travel were less than $11 \%$ of transport emissions in 2010 (Sims et al., 2014), they will likely be of increasing importance (Nava et al., 2017).

These facts raise the question of what factors affect the selection of fleet fuel economy by airlines across countries. Do increases in fuel price or a reduction of capital costs improve long-run fleet fuel economy more? Are larger or smaller airlines likelier to invest in fuel efficiency, while controlling for plane size? Are there any regional variations? In this paper, we construct a unique dataset for 1267 airlines, using plane-level technical efficiency data to answer these questions. The purpose of this paper is to understand what determines the technically achievable efficiency level of airline fleets, assuming airlines intend to utilize their fleet in the most efficient way, for example flying long-range planes on longer routes. We do not however study how airlines utilize their existing planes under different economic circumstances (see Kahn and Nickelsburg, 2016). Therefore, the term "fleet fuel economy" denotes the technically achievable fleet fuel economy of airlines in this paper.

Our estimates increase the understanding of how key long-run cost components impact on airline fleet fuel economy, and aid policy design aimed at increasing industrial efficiency as countries work to deliver their Paris Agreement (2015) emission reductions pledges. Such policies are especially important, as currently there is no set of agreed international environmental and emissions standards for air transport (ICAO, 2016), with the Carbon Offsetting and Reduction Scheme for International Aviation (CORSIA) scheme only coming into effect in 2021 on a voluntary basis. 
Our approach extends the literature in several key ways. First, the dataset used is more comprehensive than in any other publication before. We have collected technical data on over 140 airplanes to determine fleet fuel economy based on the number and type of aircraft flown for each carrier. The use of this data pose some challenge however, as other data such as wages had to be approximated for a large number of airlines. Second, we introduce two new fleet fuel economy measures, which remove the impact of aircraft size and age, thereby effectively allowing us to concentrate on the effect of non-technical variables with policy implications.

Simple (or observed) fleet fuel economy is the seat weighted fleet fuel economy of the various aircraft models used by an airline. Larger (Babikian et al., 2002) and newer aircraft tend to be more fuel-efficient. Though airlines can improve fuel economy by using larger planes, the main reasons for using larger aircraft are route distance and traffic volume. Therefore, we construct a "size-adjusted fleet fuel economy" measure, which removes the technological effect of aircraft size from aircraft fuel economy before computing fleet fuel economy. Though a major reason for using newer aircraft is to reduce fuel costs there will also be other motivations such as improving passenger comfort and reducing maintenance costs. Therefore, we also compute a "size- and age-adjusted fleet fuel economy." Finally, this allows us to report the responsiveness of fleet fuel economy to fuel prices, which has not been done before. A number of studies deal with the historical and projected development of aircraft fuel efficiency (Babikian et al. 2002; Lee et al. 2001; Lee, 2010; Peeters et al., 2005, Zou et al., 2014), the impact of fuel prices on airline operations and finances (Adrangi et al. 2014; GAO, 2014; Kahn and Nickelsburg, 2016; Murphy et al., 2013), airline profitability (Berry and Jia, 2010; Borenstein, 2011), fleet scheduling and optimization (Naumann and Suhl, 2013; Rosskopf et al. 2014), and the impact of a carbon price on firm value (Vespermann and Wittmer, 2011; Scheelhaase et al., 2010, Murphy et al., 2013, Anger and Koehler, 2010). Also, a few studies estimate cost or production functions for relatively small numbers of airlines (e.g. Caves et al., 1984; Gillen et al., 1990; Oum and Yu, 1998; Coelli et al., 1999; Inglada et al., 2006). However, we are not aware of a study of similar scale to ours that systematically examines the factors affecting airlines' choice of fuel economy.

Our model is based on a long-run translog cost function where cost depends, inter alia, on the fuel economy of the planes owned or leased by each airline. We find that higher domestic fuel prices and greater airline size are associated with better fleet fuel economy. The elasticity of fuel economy with respect to the price of fuel is between -0.07 and -0.13 . Higher capital 
costs are associated with lower fleet fuel economy. Therefore, policies aiming at higher fuel prices such as the removal of fuel subsidies or the introduction of carbon taxes would all result in increased fleet fuel economy. If induced technical change reduced the cost of more fuel-efficient aircraft, the effect could be larger than this. Reduced costs of credit, for example through loan guarantees enabling economy investments, would especially benefit those airlines that face high credit costs. Most such airlines are in developing countries.

The paper is structured as follows: Section 2 reviews the relevant literature, Section 3 introduces our model, Section 4 our data, Section 5 presents the results, and Section 6 concludes.

\section{Airline Fuel Economy}

Aircraft fuel efficiency has been improving over time (EASA, 2016; GAO, 2014; IEA 2009; Peeters et al., 2005), even though the rate of efficiency improvement is currently slowing (IEA, 2009; Peeters et al., 2005), as airplane designs get closer to the technical optimum. At the same time natural diffusion processes might not "reliably spread the best innovations" in the market (Greve and Seidel, 2015). The IEA (2009) asserts that in the United States, technological and operational improvements led to a $60 \%$ improvement in the energy efficiency of aircraft between 1971 and 1998, even though the majority of improvements happened prior to the 1980s. On the other hand, there was an earlier decline in fuel economy due to the shift from piston engine to jet engine aircraft. (Peeters et al., 2005) The EASA (2016) reports that the mean age of European aircraft is increasing. This highlights the problem that the diffusion of newer, (more) efficient technology is generally slow and gradual (Jaffe and Stavins, 1994), with the IEA (2009) noting that the average efficiency of fleet stock may lag 20 years behind new aircraft efficiency. ${ }^{1}$

Many factors affect airlines' decisions on the portfolio of planes they choose to hold and operate, including the average distance of the flights (long or short haul) usually flown, the fuel economy of the available aircraft, expected fuel prices (IEA, 2009), the price of new and

\footnotetext{
${ }^{1}$ Zou et al. (2014) find by studying 15 large jet operators in the US that the mean airline fuel efficiency in 2010 was 9-20\% worse than that of the most efficient carrier, while the least efficient airlines were $25-42 \%$ behind industry leaders in terms of efficiency. Therefore, the hypothetical cost savings from enhanced efficiency for mainline airlines could be in the vicinity of a billion dollars in 2010.
} 
used aircraft, financing requirements including owning vs. lease decisions (Gavazza, 2011), and the wages of staff.

For North American airlines the two largest expenditure items are fuel and labor (Neumann and Suhl, 2013). Kahn and Nickelsburg (2016) estimate ${ }^{2}$ that fuel prices make up about $25 \%$ of the operating expenses of US airlines, however, when kerosene and aviation fuel prices are higher, the cost share of fuel can go up to 33\% (Adrangi et al. 2014). Larger planes are usually more fuel efficient per seat-km for a given load factor (Naumann and Suhl, 2013), but they are also more difficult to fill, therefore, owning or leasing high-capacity airplanes in times of high fuel prices and low passenger numbers due to economic downturns can be financially very risky. Borenstein (2011) noted, that in times of high demand, adjustment to shocks (in taxes or fuel prices) might be relatively smooth, while the large losses of US airlines during the 2000s were due to demand shocks, when sticky labor costs, high fixed costs, and high fuel costs coincided with depressed prices.

The IEA (2009) claims that fuel-efficient aircraft can deliver net economic benefits already after a couple of years of service life. They estimate that given an oil price of USD 120/bbl that the benefit of upgrading and flying more efficient planes on long haul routes approximates to annually 6 to 8 million USD. Using a 10\% discount rate and assuming 30 years useful life, this amounts to about 10 years of undiscounted fuel savings or a net present value of 60 to 80 million. Assuming a purchase price of 40 million USD, the fuel savings easily pay for the additional price of newer aircraft. ${ }^{3}$ These savings are larger the lower the discount rate is assumed to be. Since the price of oil has fallen to around USD 50/bbl since the IEA (2009) study was published, these savings have approximately halved resulting in much less incentive to improve fuel economy. However, the fleets in place in 2015 - the date of our study - will reflect the high oil prices in many recent years.

\footnotetext{
${ }^{2}$ Kahn and Nickelsburg (2016) establish a binary choice model of airline fleet replacement and operation optimization based on US data. They find that in times of high fuel prices that airlines fly less fuel efficient planes more slowly, scrap older less efficient planes earlier, and use more fuelefficient planes more.

${ }^{3}$ The United States Accountability Office (GAO) notes in its 2014 report that in response to fuel price increases airlines have taken a number of actions, including the "reconfiguration of fleets", and increasing of operational efficiency. The GAO (2014) reports that many less fuel-efficient aircraft (e.g., Boeing 737-300/400/500 and McDonnell Douglas MD-80) were retired and replaced with technologically more advanced options such as Airbus A320 and Boeing 737-700/800/900. As a result, many manufacturers saw increased demand for more fuel-efficient aircraft in the second half of the 2000 s.
} 
The relationship between fuel prices and fleet fuel economy has been the focus of longstanding academic interest. Prominent examples from road transportation include Alcott and Wozny (2014), who find that consumers value discounted future gasoline costs only $76 \%$ of what they value purchase prices. Li et al. (2009), examine the channels through which gasoline prices affect fleet fuel economy such as the purchase of new efficient vehicles and the scrapping of older vintages. Their simulations indicate that a $10 \%$ increase in fuel prices results in $0.22 \%$ increase in fleet fuel economy in the short, and $2.04 \%$ in the long run. Burke and Nishitateno (2013) find that $1 \%$ increase in gasoline price leads to $0.15-0.2 \%$ improvement in new vehicle fleet fuel economy. Klier and Linn (2010) report that a \$1 per gallon increase in road gasoline prices improves the average fuel economy of new vehicles by 0.8-1 miles per gallon. Jacobsen and van Benthem (2015) estimate that a $\$ 1$ per gallon increase in the price of gasoline results in an additional $0.5 \%$ of the fleet of least fuel efficient vehicles being scrapped while $0.4 \%$ of the fleet of most fuel efficient vehicles that would otherwise be scrapped is not.

Airlines may improve their fleet fuel economy through technological innovation and the replacement of their stock, or through increasing operational efficiency. Adrangi et al. (2014) note that efficiency improvements are necessary for long-term survival. These improvements may arise from hedging, improved scheduling, optimal pricing, through the replacement of old vintage airplanes in the fleet with advanced technology aircraft (Adrangi et al., 2014) or from strategic flight planning (Naumann and Suhl, 2013).

Firms however might be constrained in their ability to quickly transition to a significantly more fuel-efficient fleet. This constraint might arise from the necessity to first sell their older planes to buy new aircraft, therefore the associated transaction costs might be very high. Leasing planes makes it easier for airlines to replace their fleets. Accordingly, Gavazza (2011) finds that leased aircraft have 38\% shorter holding durations on average, but fly $6.5 \%$ more hours than owned aircraft. As leasing reduces transaction costs, the number of new airplane leases have been constantly increasing in recent decades. Benmelech and Bergman (2011) claim that airlines are likelier to lease than to own aircraft in states with insufficient creditor rights, while Eisfeldt and Rampini (2009) assert that credit-constrained airlines are likely to lease more. The Economist (2012) estimated that about $40 \%$ of the world's airline fleet is now rented. However, Kahn and Nickelsburg (2016) note that in times of higher jet fuel prices the lease price of efficient aircraft is also higher in the US. 
A few authors have applied cost function or production frontier approaches to modeling airline decisions. Compared to these studies, our data set includes far more airlines and has much wider geographical scope. The tradeoff to reach this level of comprehensiveness is a lack of accurate firm level data on a number of variables of interest and as a result we use proxies for some explanatory variables.

Earlier studies (e.g. Caves et al., 1984; Gillen et al., 1990) focused mostly on the North American airline industry ${ }^{4}$. More recent studies (e.g. Oum and Yu, 1998; Coelli et al., 1999; Inglada et al., 2006) have investigated small numbers of international airlines. Oum and $\mathrm{Yu}$ (1998) apply a short-run translog unit cost function and cost share equations to 22 major international airlines over 1986-93. They use a capital stock index for aircraft and ground equipment, inter alia aggregate output, labor, energy and materials prices, revenue shares of freight and mail, average stage length, a TFP index, and time fixed effects. They found that Non-Japanese Asian carriers were generally more cost competitive than the major U.S. carriers but Japanese carriers and major European carriers were less cost competitive. Coelli et al. (1999) apply a translog stochastic production frontier model to 32 international airlines in the period 1977-1990. The inputs include labor and capital and three "environmental variables" that explain "inefficiency": mean stage length, mean number of seats per aircraft, and load factor. However, they do not consider energy efficiency explicitly.

Inglada et al. (2006) estimate cost and production stochastic frontiers for 20 airlines for 19962000. The cost frontier has random efficiency terms but does not have biased technical change. Explanatory variables are KLEM prices and output measured in ton kilometers (using weight of passengers and freight), allowing for variable returns to scale. However, the study suffers from several endogeneity problems. In particular, capital prices are measured by capital expenditures divided by capacity and energy prices as energy cost divided by kilometers. However, all of these prices depend on the fuel economy and capital investment decisions made by airlines earlier, and so are not exogenous. Our paper addresses these issues by measuring the cost of capital by interest rates, and energy prices by exogenously determined gasoline prices and oil reserves.

\footnotetext{
${ }^{4}$ Applying a translog total cost function and share equations to panel data, Caves et al. (1984) found no economies of scale that affected the relative costs of "trunk" and smaller regional airlines in the U.S. Instead, density of traffic within an airline's network rather than differences in the size of the network explained cost differences.
} 


\section{Model}

We assume that the total operating costs, $C$, of airline $i$ at time $t$, is given by the long-run cost function:

$$
C_{i t}=f\left(Q_{i t}, p_{t}, d_{i t}, r_{i t}, w_{i t}, E_{i t}, \mathbf{z}_{i t}, t\right)
$$

where $Q$ is output, $p$ is the international price of fuel, $d$ is the domestic price of fuel, $r$ is the cost of capital, $w$ is the wage rate, $E$ is fleet fuel economy, $\mathbf{z}$ is a vector of "environmental variables", and the final explanatory variable indicates that technology evolves over time. While fuel for international flights is effectively untaxed, fuel used for domestic aviation is taxed in many countries (Keen and Strand, 2007). We measure fleet fuel economy, $E$, as fuel consumed per seat-km assuming aircraft are used at full capacity. Therefore, it reflects the technical characteristics of the installed capital stock rather than actual operational fuel efficiency, which is influenced by load factors (and could be measured by fuel consumption per passenger-km). However, this is not a concern as the purpose of our paper is not to study how airlines utilize their existing stock (flying at maximum range or with a full load factor), but to understand how they build up their stock, given the assumption they plan to utilize them most efficiently. For example, we assume that when an airline invests in a long-range craft, it does not intend to fly it systematically on short-routes. Environmental variables reflect the type of services provided by an airline - here we try to capture factors such as the typical flight segment length and plane. Details for all these variables are discussed in the Data Section below.

If larger aircraft are more fuel-efficient than smaller aircraft, $E$ will depend on the size of aircraft employed. If newer aircraft are more efficient for a given seat size, $E$ will depend on the age of the fleet as well. While airlines can choose larger and newer aircraft to improve fuel economy there are also other reasons why they would choose these over smaller and older aircraft. Therefore, we also investigate alternative measures of fuel economy, clean of size and age effects.

We assume that (1) can be represented by a long-run translog cost function of the following general form:

$$
\ln C_{i t}=\alpha_{0}+\ln A_{t}+\ln u_{i t}+\boldsymbol{\beta}^{\prime} \mathbf{x}_{i t}+0.5 \mathbf{x}_{i t}^{\prime} \mathbf{B} \mathbf{x}_{i t}+\mathbf{a}_{t}^{\prime} \tilde{\mathbf{x}}_{i t}+e_{i t}
$$


where $\mathbf{x}_{i t}=\left[\ln Q_{i t}, \ln p_{t}, \ln d_{i t}, \ln r_{i t}, \ln w_{i t}, \ln E_{i t}, \ln \mathbf{z}_{i t}\right]^{\prime}, \tilde{\mathbf{x}}_{i t}=$ $\left[\ln p_{t}, \ln d_{i t}, \ln r_{i t}, \ln w_{i t}, \ln E_{i t}, \ln \mathbf{z}_{i t}\right]^{\prime}$, and primes indicate transposes. $\alpha_{0}$ is a constant, $\ln A_{t}$ represents movement of the frontier due to technical change, $\ln u_{i t}$ represents the technical inefficiency of airline $i$ relative to the frontier, and $e_{i t}$ is a random error term. The vector $\mathbf{a}_{t}$ contains technical change biases. These are not restricted to interactions of a linear time trend and price. We explicitly assume that $\partial \ln C_{i t} / \partial \ln E_{i t}$ may change over time holding $\mathbf{x}_{i t}$ constant. The cost function is homogenous of degree one in input prices.

We assume that conditional on output, prices, environmental variables, and technology that there is a cost minimizing fuel efficiency level, $E_{i t}^{*}$. Partially differentiating (2) with respect to $\ln E$ we have:

$$
\begin{aligned}
\frac{\partial \ln C_{i t}}{\partial \ln E_{i t}}=\beta_{E}+ & \beta_{E Q} \ln Q_{i t}+\beta_{E p} \ln p_{t}+\beta_{E d} \ln d_{i t}+\beta_{E r} \ln r_{i t}+\beta_{E w} \ln w_{i t} \\
& +B_{E E} \ln E_{i t}^{*}+\sum_{j} B_{E j} \ln z_{i t}+a_{E t}
\end{aligned}
$$

Then setting (3) to zero, we can solve for $E_{i t}^{*}$ :

$$
\begin{aligned}
\ln E_{i t}^{*}=-\frac{\beta_{E}}{B_{E E}} & -\frac{\beta_{E Q}}{B_{E E}} \ln Q_{i t}-\frac{\beta_{E p}}{B_{E E}} \ln p_{t}-\frac{\beta_{E d}}{B_{E E}} \ln d_{i t}-\frac{\beta_{E r}}{B_{E E}} \ln r_{i t} \\
& -\frac{\beta_{E w}}{B_{E E}} \ln w_{i t}-\sum_{j} \frac{B_{E j}}{B_{E E}} \ln z_{i t}-\frac{1}{B_{E E}} a_{E t}
\end{aligned}
$$

Our empirical analysis assumes that $E_{i t}^{*}$ is at a long-run equilibrium and we estimate the following regression for a cross section, where we add a random error term to account for optimization errors, measurement errors or omitted variables etc.

$$
\ln E_{i}^{*}=\gamma_{E}+\gamma_{Q} \ln Q_{i}+\gamma_{d} \ln d_{i}+\gamma_{p} \ln r_{i}+\gamma_{w} \ln w_{i}+\sum_{j} \gamma_{i} \ln z_{i}+\varepsilon_{i}
$$

Therefore, both the common international fuel price and the technical change bias term have fallen out. One caveat of the above equation is that the domestic fuel prices might be correlated with energy efficiency policies of countries. We might assume that high fuel-tax countries would have policies encouraging efficiency improvements that are likely to result in a preference for more efficient types of planes as well. 
The airlines in the sample vary tremendously in size from 15 to 183554 total seats. It is plausible that larger airlines will find it easier to adjust to the long-run equilibrium by maintaining a portfolio of different aircraft models and gradually introducing new models. By analogy with grouping heteroskedasticity, the variance of the residuals might be inversely proportional to the total number of seats. The Breusch-Pagan test statistic for heteroskedasticity related to the total number of seats in the first regression of Table 4 is 69.62, which is distributed as chi-squared with one degree of freedom $(\mathrm{p}=0.00)$. Therefore, we present weighted least squares (WLS) estimates as a robustness check, where the weights are the square root of the total number of seats available to each airline. We compute robust standard errors clustered by country for both OLS and WLS models. Using WLS together with heteroskedasticity consistent standard errors should result "in valid inference, even if the conditional variance model is misspecified" (Romano and Wolf, 2017, 2).

\section{Data}

\section{$\underline{\text { Aircraft data }}$}

Our data on the aircraft operated by each airline is taken from the World Airliner Census (Flightglobal, 2015). The Census gives a snapshot as of 2015 of the type and number of different types of aircraft operated (owned and leased) by commercial airlines and air-freight companies throughout the world. After deleting 5 airlines for which we could not determine their country of registration, we have data on 1267 different airlines.

While the census data include "all commercial jet and turboprop-powered transport aircraft, built by Western, Chinese or Russian/CIS/Ukrainian manufacturers in service”, as well as company orders, for the purpose of this study, we excluded not-yet delivered orders from the dataset. Flightglobal (2015) defines an aircraft "in service" when it is "active (in other words accumulating flying hours).”

The census data include all cargo, passenger and multi-purpose planes. We excluded aircraft types that are only used for cargo flights from the dataset, ${ }^{5}$ as no seat number could be determined. If a plane is multi-purpose and can be operated both as a passenger plane and as cargo, we included it. Planes with fewer than 14 seats are excluded from the World Airliner

\footnotetext{
${ }^{5}$ Airbus A330-200F, Airbus C212, Antonov AN-12, Antonov AN-30, Antonov AN-124, Antonov AN-178, Antonov AN-225, Boeing 777F, GAF Nomad, Harbin Y-12, Ilyushin IL-76, Lockheed L100 HERCULES, Lockheed L-188 ELECTRA, McDonnell-Douglas DC-3
} 
Census data. We have allocated airlines to the countries where their company offices are registered. We determined the locations using information available on the Internet, such as ch-aviation.com, flightglobal.com, and other sources.

\section{Technical Characteristics and Fuel Economy}

We determined the maximum range, maximum fuel capacity, typical number of seats, and the year of first flight for each of the 143 aircraft types in our dataset. We used original company documentation from Airbus, Boeing, and other manufacturers, which are openly available on the Internet. For a small number of older aircraft, and for some specific models of a given type of aircraft we could not locate technical data. In this case, we took the data of the most similar model of the same type of aircraft, or the data for a different type of aircraft from the same manufacturer. ${ }^{6}$ The exact list of aircraft used, their technical data, and the sources for the technical data are in the Appendix.

As explained above, we use three alternative measures of fleet fuel economy in our study. We calculate the simple (observed) fuel economy of aircraft model $j, E_{j}$, as follows:

$$
E_{j}=\frac{F_{j}}{R_{j} S_{j}} * 100
$$

where $F$ denotes maximum fuel capacity, $R$ maximum range in kilometers, and $S$ is the typical number of seats. ${ }^{7}$ Fuel economy of each airline fleet is calculated by weighting aircraft model fuel economy by the total number of seats available for model $j$ for that airline, $S_{j i t}$, dividing by the total number of seats on all aircraft available to that airline, $S_{i t}$, and summing over all models:

$$
E_{i t}=\sum_{j=1}^{J} \frac{S_{j i t}}{S_{i t}} E_{j}
$$

Thus the metric we have is the average efficiency per seat in a fleet, calculated across the different aircraft types. Lower values indicate higher fleet fuel economy.

\footnotetext{
${ }^{6}$ These changes are documented in the Technical Appendix.

${ }^{7} \mathrm{We}$ used typical number of seats in an aircraft. However, in some cases only maximum numbers were available. The exact sources and the seat number specifications are found in the Technical Appendix.
} 
To account for the fact that larger aircraft tend to be more fuel-efficient, we also construct an alternative, "size-adjusted" fuel economy measure, clean of the effect of aircraft size. The reason we adjust the dependent variable rather than control for size in the regression analysis is that our intention is to remove only the technology effect of aircraft size on fuel economy. There may also be a behavioral effect of aircraft size on the choice fuel economy. This is done by regressing $E_{j}$ on the average number of seats $S_{j}$ for that model:

$$
\ln E_{j}=\gamma_{0}+\gamma_{1}\left(\ln S_{j}-\overline{\ln S}\right)+\sum_{k=1}^{K} \gamma_{k+1} d_{k j}+\varepsilon_{J}
$$

where $\overline{\ln S}$ is the mean of $\ln S_{j}$ across all aircraft models. Because average aircraft size may have increased over time, we include K-1 decadal dummies, $d_{k}$, for each decade prior to the most recent decade. These control for the time of the first flight of each aircraft model ${ }^{8} \mathrm{We}$ then predict size-adjusted fuel economy for each plane model:

$$
E_{j}^{A}=\exp \left(\ln E_{j}-\gamma_{1}\left(\ln S_{j}-\overline{\ln S}\right)\right)
$$

We then aggregate aircraft model fuel economy to airline level as before, giving us a sizeadjusted fleet fuel economy:

$$
E_{i t}^{A}=\sum_{j=1}^{J} \frac{s_{j i t}}{s_{i t}} E_{j}^{A}
$$

Our third measure, size and age adjusted fleet fuel economy, also removes the effect of model age from the fleet economy variable:

$$
E_{j}^{B}=\exp \left(\ln E_{j}-\gamma_{1}\left(\ln S_{j}-\overline{\ln S}\right)-\sum_{k=1}^{K} \gamma_{k+1} d_{k j}\right),
$$

We aggregate as before:

$$
E_{i t}^{B}=\sum_{j=1}^{J} \frac{S_{j i t}}{S_{i t}} E_{j}^{B}
$$

Wages:

We estimate wages $(w)$ based on the available wage data in the ICAO (2015) database. A small number of airlines have wage data in nominal US dollars converted at market exchange

\footnotetext{
${ }^{8}$ Where data on the year of the first flight was not available, we allocated a decade based on our best guess. These assumptions are documented in the Appendix.
} 
rates for 2015 in the ICAO database. For these airlines we compute an average wage for all staff at the airline. We use mid-year data on staff numbers unless only year-end data were available. Some of this data is clearly anomalous and we deleted obviously incorrect values. This includes all average wages above $\$ 200,000$ and $\$ 1,000 .{ }^{9}$ For airlines without apparently reliable 2015 data but seemingly reliable wage for earlier years in the database, we used that earlier wage to project the wage in 2015 using the parameters from a within airline regression (i.e. using fixed effects for each airline) reported in Table 2. For Venezuela we used 2013 estimates. We could estimate wages for 491 airlines in this manner. The within regression regresses the logarithm of wages on GDP per capita data both in nominal US dollars converted at market exchange rates. Table 1 presents these results:

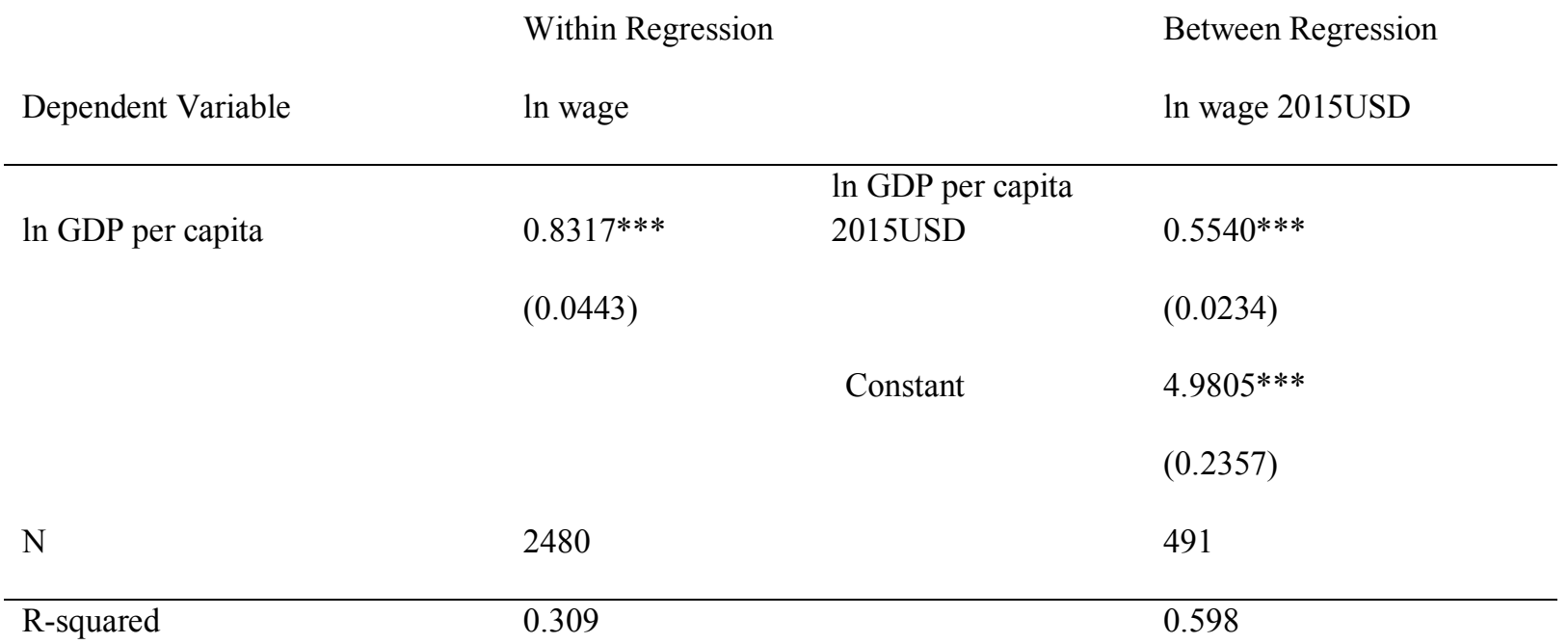

Heteroskedasticity robust standard errors in parentheses. Standard errors for within regression are clustered by airline.

$* \mathrm{p}<0.10, * * \mathrm{p}<0.05, * * * \mathrm{p}<0.01$

Table 1: Wage Regressions

The regression shows that wages increase by $0.83 \%$ for a $1 \%$ increase in GDP per capita. This coefficient is significantly less than 1 . We project the 2015 wage rate as follows:

$$
\ln \widehat{W}_{i, 2015}=\ln \widehat{W}_{i, b}+0.8317\left(\ln G_{i, 2015}-\ln G_{i, b}\right)
$$

where $\widehat{W}_{i, 2015}$ is the projected wage, $W_{i, b}$ is the wage in the base year, and $G_{i, 2015}$ and $G_{i, b}$ are GDP per capita in 2015 and the base year respectively in USD converted at market exchange rates.

\footnotetext{
${ }^{9}$ We did use a value of $\$ 834$ in 2006 for Kyrgyzstan Airways to project the 2015 value.
} 
Where no reliable wage data are available in the ICAO database we use the following regression procedure: first we converted all apparently reliable nominal wages to 2015 US Dollars using the US implicit GDP price deflator. We converted the GDP per capita for the relevant country and year in the same way. We then used the between estimator to estimate a regression of the log of wages on GDP per capita. The results are also in Table 1. A pooled OLS regression on the sample of 2480 original data points produces almost identical results. As we would expect, airline jobs are relatively well paying in poor countries and so the elasticity is substantially less than unity. We then used the between regression results to project wages to the remaining airlines using observations on GDP per capita in 2015 in US dollars converted at market exchange rates in the relevant country:

$$
\ln \widehat{W}_{i, 2015}=4.9805+0.5540 \ln G_{i, 2015}
$$

where $\widehat{W}_{i, 2015}$ is the projected wage and $G_{i, 2015}$ is 2015 GDP per capita in USD converted at market exchange rates. Where 2015 data were not available, we used the most recent year from the World Development Indicators. We used the Penn World Table to obtain values for 2014 for Syria and Taiwan. We used a variety of online sources for a number of small island countries such as the Cook Islands, Greenland, and Guam and for North Korea.

\section{Interest Rates}

Real interest rates $(r)$, which we use as proxy for the cost of capital, were sourced from the World Bank (2017) and the ECB (2017). ${ }^{10}$ The World Bank uses the data from the International Monetary Fund, International Financial Statistics and its GDP deflator, to calculate real interest rates. As the World Bank data are missing interest rates for a large number of countries including all countries in the Euro Area, we calculated the real interest rates for a number of European countries, by using the ECB's (2017) composite cost of borrowing on new loans for non-financial corporations and deflating it with the World Bank’s (2017) deflator. ${ }^{11}$

\footnotetext{
10 "Real interest rate is the lending interest rate adjusted for inflation as measured by the GDP deflator. The terms and conditions attached to lending rates differ by country, however, limiting their comparability." (World Bank definition, series: FR.INR.RINR)

11 "Inflation as measured by the annual growth rate of the GDP implicit deflator shows the rate of price change in the economy as a whole. The GDP implicit deflator is the ratio of GDP in current local currency to GDP in constant local currency." (World Bank definition, series:

NY.GDP.DEFL.KD.ZG).
} 


\section{Output}

We approximate output, which measures the effect of economies of scale, as the total seats available to an airline. This assumes that all airlines operate all plane types for the same fraction of available time with the same loading. Obviously, a more direct measure of traffic volume such as passenger-miles flown would be a better measure of output. While the IATA does offer monthly traffic data for some of its member carriers, the reported numbers are voluntary and only cover at most 130 airlines.

The airline industry is highly heterogeneous within and across countries. As we cover 174 countries in our sample, we had to make a number of simplifying assumptions in order to estimate our models. One of the limitations of the estimation is the assumption that airlines use all airplanes with the same loading and for the same fraction of time. In truth, load factors vary significantly across airlines. Due to the very large number of airlines used, such load factors were not available, without reducing our sample size ten-fold.

\section{$\underline{\text { Aviation Fuel Price }}$}

Data on aviation fuel prices are not readily available for our dataset on a country level. While fuel on international flights is untaxed, countries within their jurisdiction may choose to tax domestic aviation fuel. Fuel prices for international flights at international trading hubs vary slightly. Also, airlines might not refuel in their country of origin, but might do so while flying different "legs" of their international routes and fuel prices for domestic and international airlines in some countries may differ. Platts offers jet fuel price comparison on a regional (continental) basis for one day of a year, and daily spot prices for several major trading hubs are only available on a subscription basis. Below is a snapshot of regional jet fuel prices as of 25 April 2017: 


$$
\text { Share in World Index } \quad \text { cts/gal } \$ / \mathrm{bbl} \quad \$ / \mathrm{mt} \quad \begin{gathered}
\text { Index value } \\
2000=100 \%
\end{gathered}
$$

Platts Global Index

$100 \%$

$148.6962 .45 \quad 492.42 \quad 170.71 \%$

\section{Platts Regional Indices}

\begin{tabular}{|c|c|c|c|}
\hline Asia \& Oceania & $22 \%$ & $\begin{array}{lll}148.35 & 62.31 & 492.23\end{array}$ & $178.03 \%$ \\
\hline Europe \& CIS & $28 \%$ & $148.8962 .53 \quad 492.75$ & $168.48 \%$ \\
\hline Middle East \& Africa & $7 \%$ & $144.33 \quad 60.62 \quad 478.28$ & $181.02 \%$ \\
\hline North America & $39 \%$ & 148.7862 .49493 .64 & $166.12 \%$ \\
\hline Latin \& Central America & $4 \%$ & $155.93 \quad 65.49504 .28$ & $181.42 \%$ \\
\hline
\end{tabular}

Table 2: Platts Jet Fuel prices: snapshot from: http://www.platts.com/jetfuel, 26 April 2017.

The lowest average jet fuel prices are in the Middle East and Africa, and the highest prices in Latin and Central America. At the same time, the differences are not major, with only $8 \%$ difference between the lowest and highest price range. Given all this, we decided to assume that the international fuel price faced by each airline was the same and so in our crosssectional estimation is absorbed into the constant.

We use different proxies for the domestic aviation fuel price, including the World Bank's (2017) information on road gasoline prices, ${ }^{12}$ oil rents as a fraction of GDP,,${ }^{13}$ and proven oil reserves per capita (Burke, 2013).

\section{Environmental Factors}

The environment, $\mathbf{z}$, in which airlines operate has a significant impact on their cost function.

For our simple fleet fuel economy model, which does not remove the effects of aircraft size and model age from estimated fleet fuel economy, we alternatively control for the average seat size within a fleet, and for the estimated maximum age of the fleet. The vintage (V) of

\footnotetext{
12 "Fuel prices refer to the pump prices of the most widely sold grade of gasoline. Prices have been converted from the local currency to U.S. dollars." (World Bank definition, series: EP.PMP.SGAS.CD).

13 "Oil rents are the difference between the value of crude oil production at world prices and total costs of production.”(World Bank definition, series: NY.GDP.PETR.RT.ZS.CD)
} 
the fleet is calculated by deducting the year of the first (YF) flight for a specific model from 2015:

$$
V_{i, t}=2015-Y F_{i, t}
$$

This gives us the maximum age of a specific aircraft flown in a fleet. We take the seat weighted average of the aircraft age, in a given fleet, giving us effectively the maximum age of a seat in a fleet.

$$
V_{i t}=\sum_{j=1}^{J} \frac{S_{j i t}}{S_{i t}} V_{j}
$$

The average seat size within a fleet is calculated in a similar manner:

$$
S_{i t}=\sum_{j=1}^{J} \frac{S_{j i t}}{S_{i t}} S_{j}
$$

All models also control for country area and population. These variables control for the fact that larger countries in both population and area might see a higher number of flights between cities and this might not simply be a function of either area or density. A higher average distance between cities would increase the share of domestic travel that takes place by air. While small countries usually would have more international air travel relative to domestic, a large small population country such as Australia might also have relatively more international travel than a large more densely populated country such as China. Country area controls for the increased likelihood of internal flights, which face the domestic fuel price. Both variables are sourced from the WDI (World Bank, 2017).

We control for the general air-traffic activity in a country by using data on the number of passengers carried per country (World Bank, 2017). ${ }^{14}$ We also control for unobserved geographical and regional characteristics of the area airlines operate in, using dummy variables for the World Bank's regional classification including, East Asia and Pacific, Europe \& Central Asia, Latin America \& Caribbean, Middle East \& North Africa, North America, South Asia, and Sub-Saharan Africa. East Asia and Pacific is the default region in our regressions.

\footnotetext{
14 "Air passengers carried include both domestic and international aircraft passengers of air carriers registered in the country" (World Bank definition, series: EP.PMP.DESL.CD).
} 


\section{Results}

\subsection{Characteristics of airline fleet fuel economy}

Figure 1 presents the relationship between aircraft seat fuel economy, and the first year of flight. The Figure shows that on average the fuel economy of new aircraft models has been improving over the past 70 years, in line with our expectations.

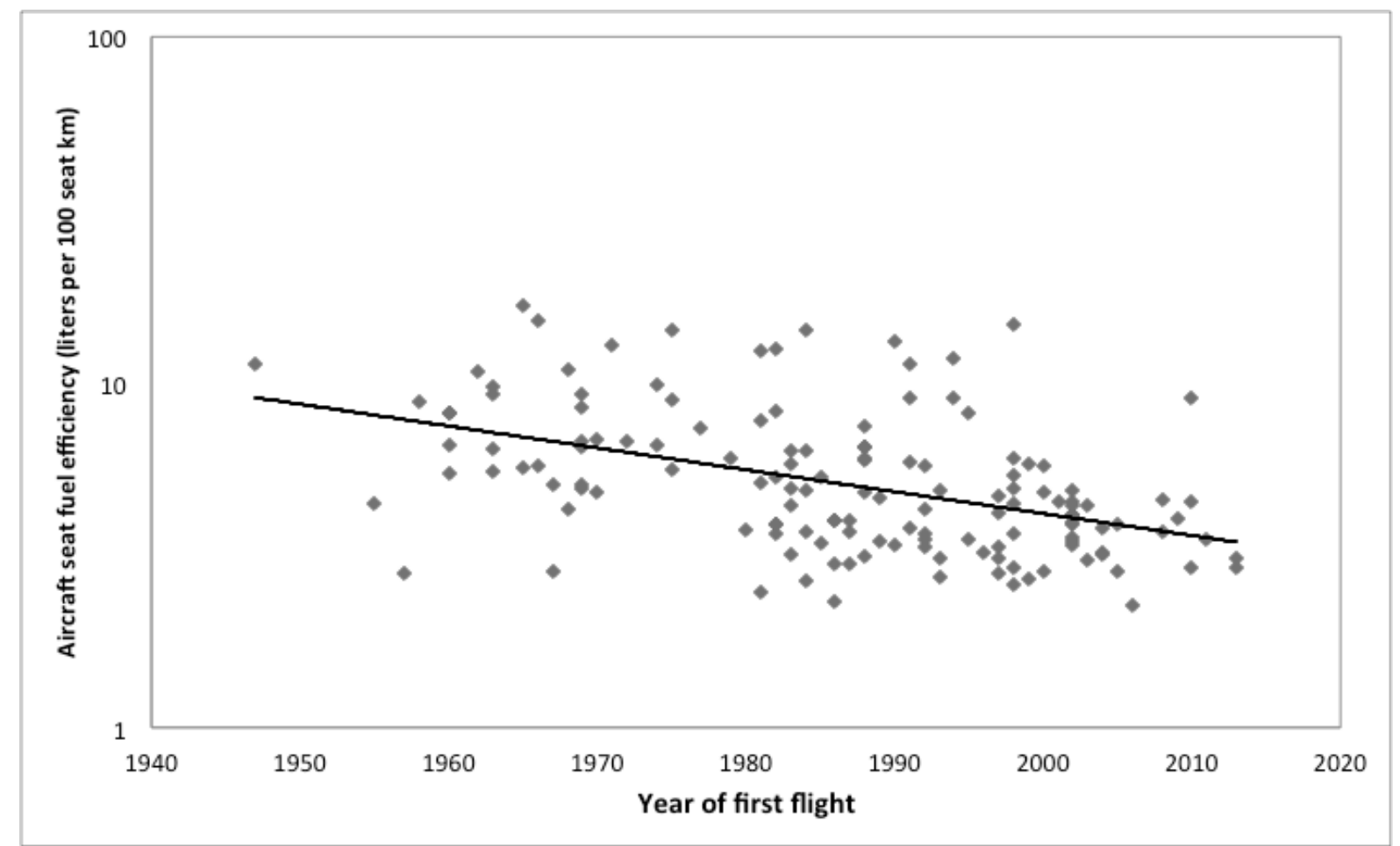

Figure 1: Aircraft fuel economy in the year of first flight for a sample of 143 aircraft models

Aircraft have also become larger over time, which is one of the main drivers of simple fuel economy. Figure 2 depicts the relationship between seat size and aircraft fuel economy. This relationship appears to be linear on a log scale meaning that while fuel economy improvements have progressed at a constant percentage rate, in absolute numbers there have been slowing incremental improvements, despite increases in aircraft size and other independent technical improvements. These findings are in line with the IEA's (2009) report on slowing efficiency gains as new aircraft models get closer to the technologically 


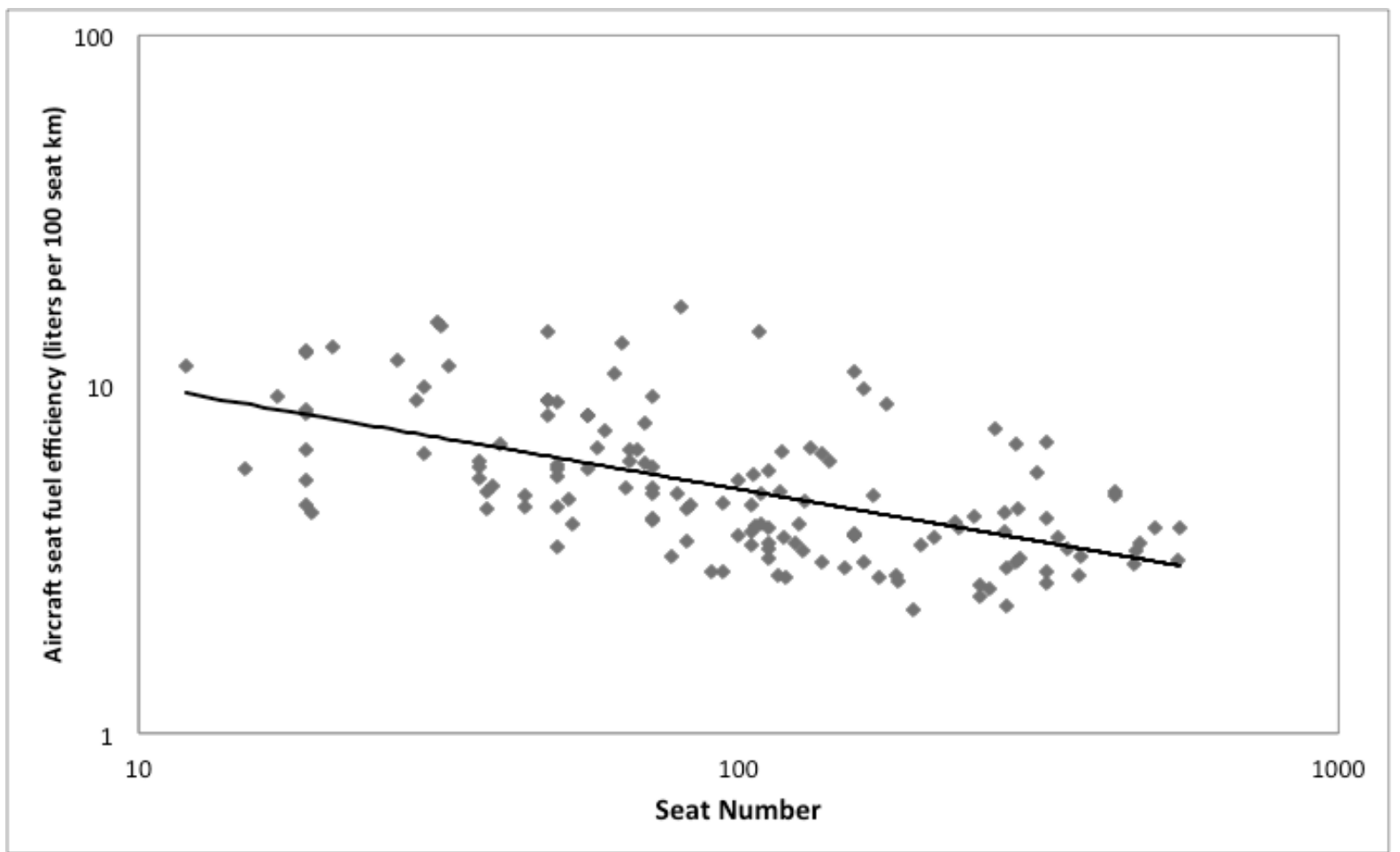

Figure 2: Aircraft fuel economy and seat numbers for a sample of 143 aircraft models.

\begin{tabular}{|c|c|}
\hline & $\ln$ efficiency 1 \\
\hline \multirow[t]{2}{*}{ Demeaned Log Seats } & $-0.274 * * *$ \\
\hline & $(0.0333)$ \\
\hline \multirow[t]{2}{*}{$1940 \mathrm{~s}$} & $0.280 * * *$ \\
\hline & $(0.0971)$ \\
\hline \multirow[t]{2}{*}{$1950 \mathrm{~s}$} & -0.00663 \\
\hline & $(0.335)$ \\
\hline \multirow[t]{2}{*}{$1960 \mathrm{~s}$} & $0.304 * *$ \\
\hline & $(0.138)$ \\
\hline \multirow[t]{2}{*}{$1970 \mathrm{~s}$} & $0.537 * * *$ \\
\hline & $(0.0968)$ \\
\hline \multirow[t]{2}{*}{$1980 \mathrm{~s}$} & -0.00112 \\
\hline & $(0.0841)$ \\
\hline \multirow[t]{2}{*}{$1990 \mathrm{~s}$} & 0.0121 \\
\hline & $(0.0903)$ \\
\hline \multirow[t]{2}{*}{$2000 \mathrm{~s}$} & $-0.168 * *$ \\
\hline & $(0.0755)$ \\
\hline \multirow[t]{2}{*}{ Constant } & $1.468 * * *$ \\
\hline & $(0.0648)$ \\
\hline $\mathrm{N}$ & 143 \\
\hline adj. R-sq & 0.468 \\
\hline \multicolumn{2}{|c|}{ Standard errors in parentheses } \\
\hline \multicolumn{2}{|c|}{$* \mathrm{p}<0.10, * * \mathrm{p}<0.05, * * * \mathrm{p}<0.01$} \\
\hline
\end{tabular}

Table 3: The effect of seat size and the decade of first flight on aircraft fuel economy. 
achievable fuel efficiency levels. Noteworthy, older aircraft sometimes get retrofitted with newer engines and wingtips etc. Our data cannot capture such retrofitting.

Table 3 shows the magnitude of the impact of aircraft size on efficiency, while controlling for the fact that technology has been changing over time. We find that planes with more seats are significantly more fuel-efficient independent of the time effect. The numbers indicate that aircraft introduced in the 1940s, 1960s, and 1970s were significantly less fuel-efficient than recent aircraft, ceteris paribus. Aircraft introduced in the first decade of the $21^{\text {st }}$ Century were more fuel-efficient.

To remove the significant impact of plane size on efficiency - in order to focus on variables that can be influenced by energy policy rather than technological features -, we created sizeadjusted aircraft fuel economy as described in the Data Section. Figure 3 plots seat weighted airline fleet fuel economy against size-adjusted economy.

Less (more) fuel-efficient airlines tend to look relatively more (less) efficient using size adjusted fuel economy than simple fuel economy. Because larger airlines in terms of the total number of seats also tend to use larger aircraft, this correction also means that the relationship between fuel economy and airline size should be less pronounced using size adjusted fleet fuel economy than simple fuel economy. Figure 4 shows the relationship between simple fleet fuel economy and airline size. Larger airlines tend to fly longer legs with larger aircraft, therefore their seat weighted simple fuel economy will be better due to the higher number of large aircraft.

In Figure 5 we show the impact of airline size on size adjusted fleet fuel economy. As expected, the relationship is less strong, but importantly still suggests that there are economies of scale. This means that even after controlling for the efficiency improvements arising from the size of aircrafts, big airlines tend to fly more efficient fleets. This might be either due to the impact of fleet age or a better investment strategy. 


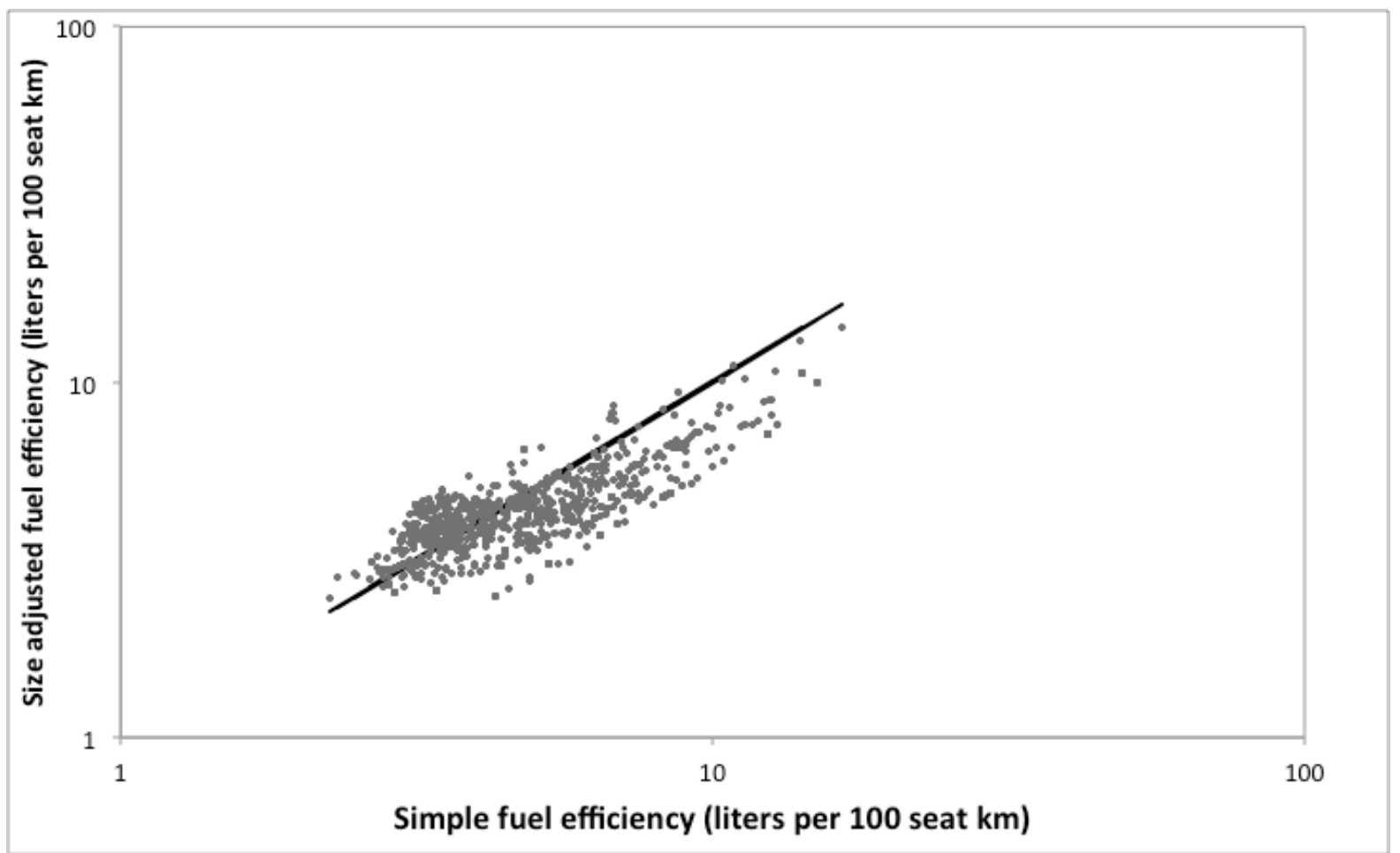

Figure 3: Airline simple fleet fuel economy vs. size-adjusted airline fleet fuel economy for 1267 airlines. The solid line represents a 45 degree line.

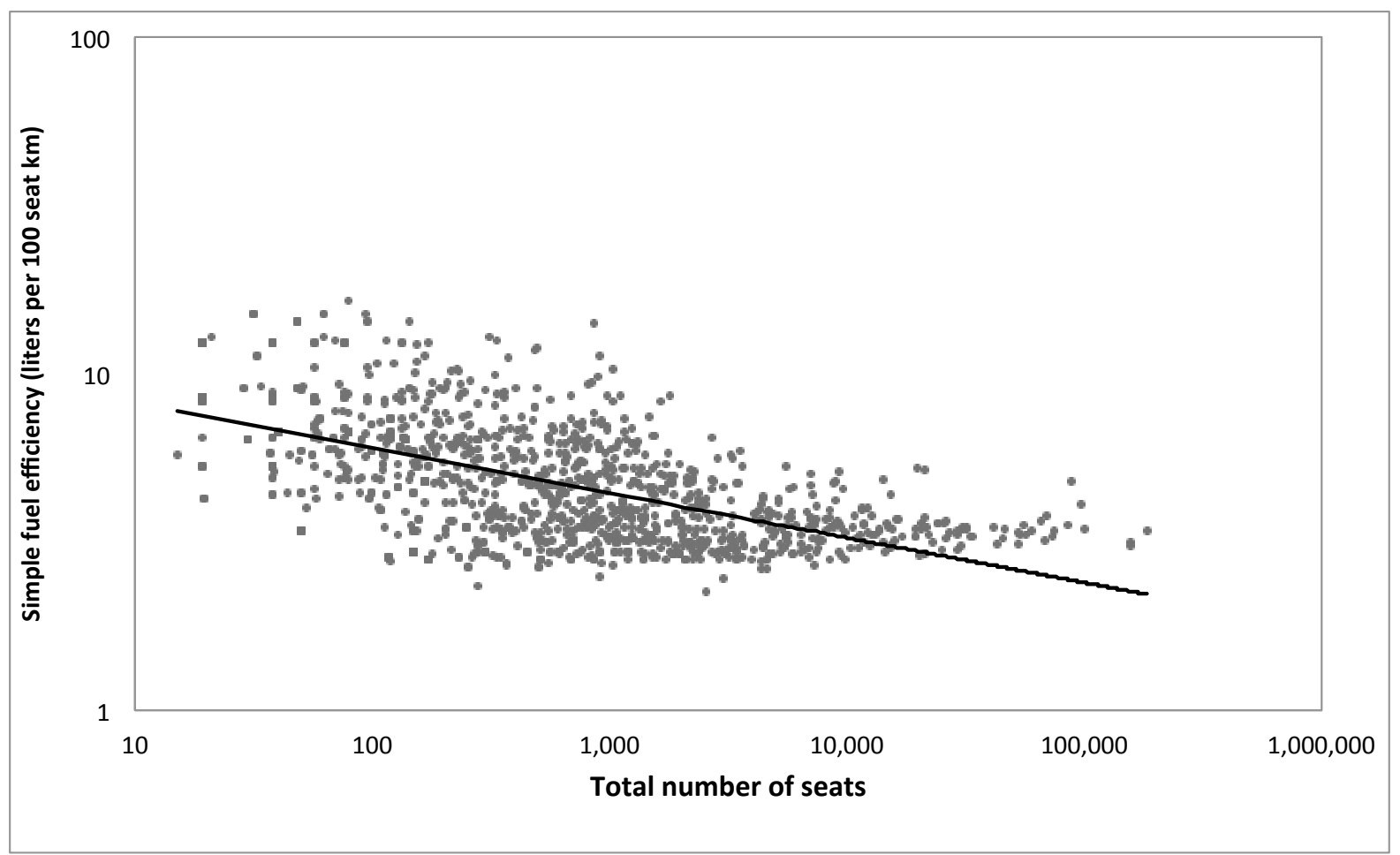

Figure 4: Airline simple fleet fuel economy and total number of seats 


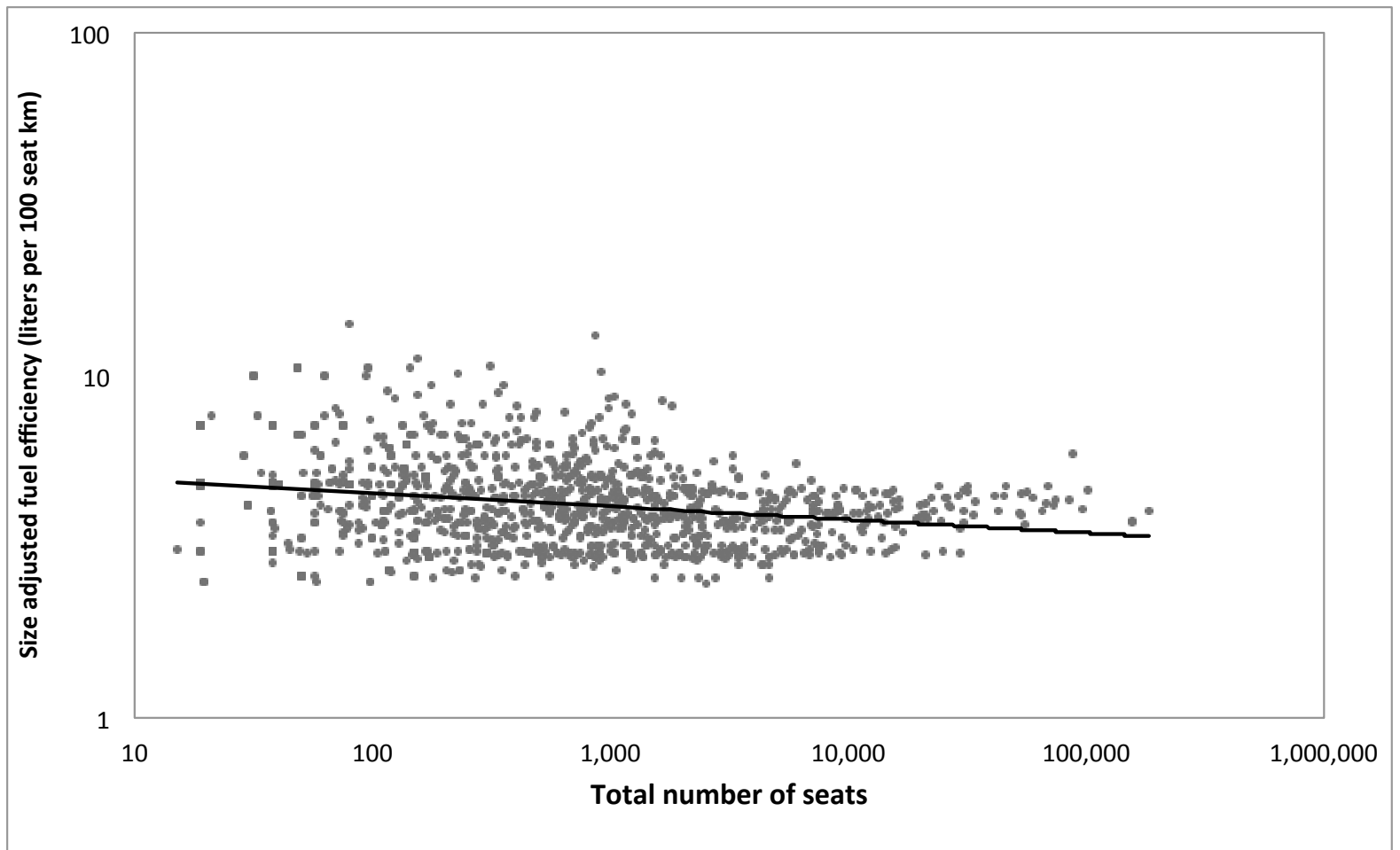

Figure 5: Airline size adjusted fleet fuel economy and total number of seats

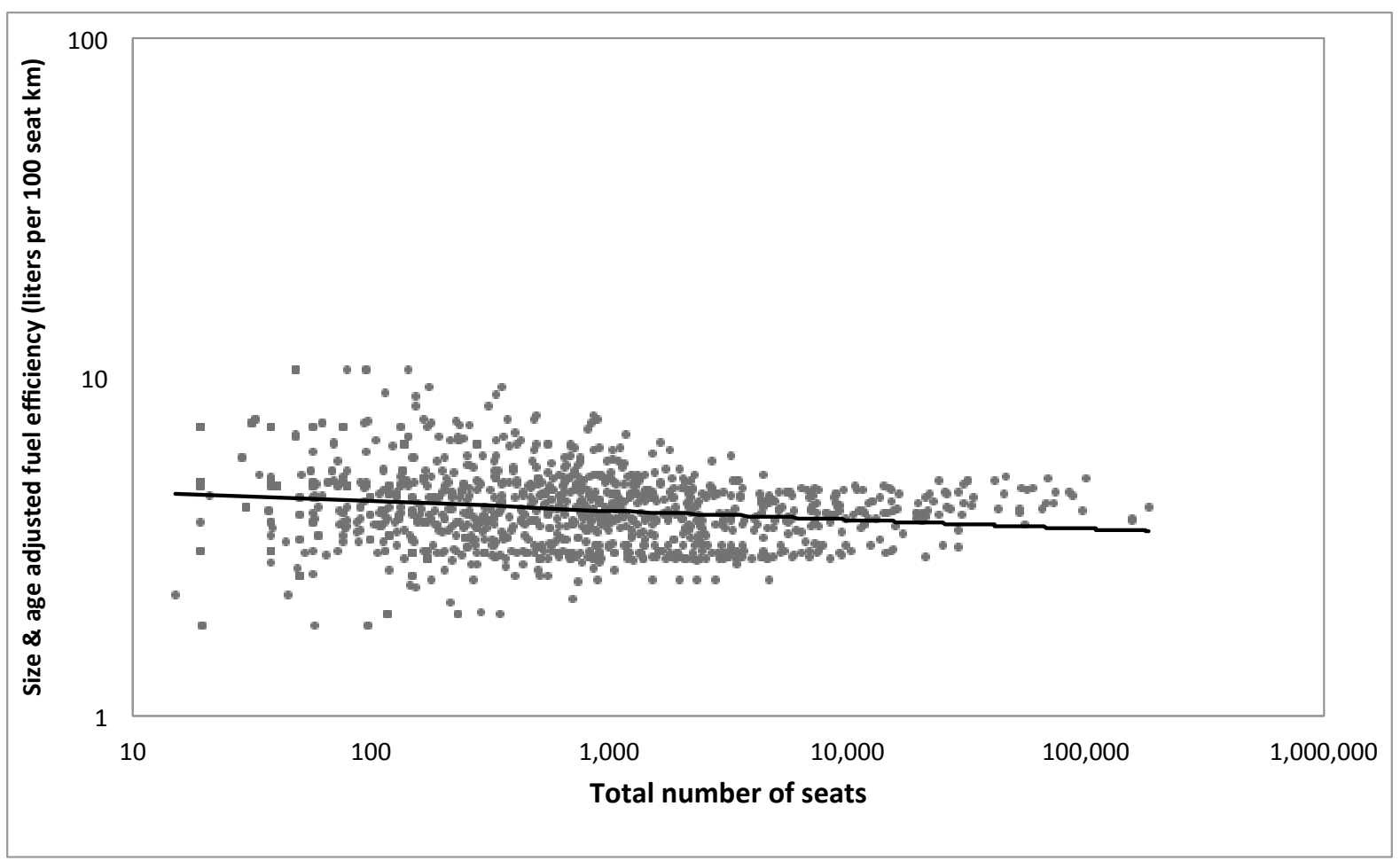

Figure 6: Airline size and age adjusted fleet fuel economy and total number of seats

Among the ten largest airlines in the world (over 70,000 total seats), five airlines (including the first three) are from the United States, two from China, and one from each of the UEA, the UK, and Germany. In our sample, 85 airlines have more than 10,000 total seats, while the majority $(65 \%)$ of airlines have less than 1,000 total seats. When we rid the efficiency 
measure both of aircraft size and age, the relationship flattens again, indicating that larger airlines fly both larger and newer types of planes.

Average airline fuel economy of the 1267 airlines in our sample, has a mean value of 5.28 (liter/hundred seat-km), while the most efficient airline's efficiency is 2.25 (liter/hundred seat-km), and the least efficient airline's efficiency is at 16.56 liter/hundred seat-km. These are the observed (actual) values. Accounting for differences in aircraft size, the modified efficiency measure shows a hypothetical average of 4.44 liter/hundred seat-km, with the most efficient airlines at 2.46, and the least efficient at 14.18 liter/hundred seat-km. Accenting for both size and age effects, the average is found at 4.27 , the minimum at 1.83 and the maximum at 10.58 liter/seat-km. These statistics show that the differences in efficiency in a worldwide sample are far greater than the variation reported by Zhou et al. (2014) for the US.

\subsection{Factors influencing airlines' choice of fleet fuel economy}

Tables 4, 5, and 6 report the results of Eq. (5) for simple, size adjusted, and size and age adjusted fleet fuel economy. The explanatory variables in each table are the same except we control for the average number of seats and the average age of the fleet in Columns 3 and 4 in Table 4, where the dependent variable is simple fuel economy and for average age in Columns 3 and 4 in Table 5, where the dependent variable is size-adjusted fuel economy. These provide an alternative way of removing the effects of size and model age. However, they will remove both the possible effect of these variables on the behavior of airlines as well as the purely technical effect of size and model age on model fuel economy. Therefore, we prefer the estimates in Table Columns $1 \& 2$ to those in Columns 3 and 4 in Tables 4 and 5. The R squared in Table 4, Columns 3 and 4 is high. The variables explain $56 \%$ of the variation in simple (or observed) fleet fuel economy. In contrast, the R squared in successive tables is lower, because we removed the effect of plane size and age from the observed fuel economy variable, and from the regressors as well.

The effect of economies of scale is measured by the natural logarithm of the total number of seats, given that the average number of seats in an airline are directly controlled for (Tab.3, Cols 3 and 4), or size-adjusted efficiencies are used (Tab. 4 and 5). The coefficient on the log total number of seats is highly significant and negative in all regressions in Tables 4 to 6 . In Table 4 Columns 1 and 2, where the dependent variable is simple fuel economy the coefficient of $\log$ total number of seats is largest (in absolute value) at -0.132 . However, when we control for the average size and age of plane (Columns 3 and 4) the effect size is 
much smaller at -0.025 to -0.026 . Here though the partial effect of a change in total seat number is equivalent to that of a change in the number of planes the airline operates. In Table 5 (Columns 1 and 2) the returns to scale effect is -0.038 . Here the dependent variable adjusts for the technical effect of plane size on fuel economy. In Table 6, where the dependent variable is adjusted for model age, which reduces the variation in fuel economy further, the returns to scale effect is only -0.026 , though still statistically significant. There may be various reasons why we find economies of scale. For example, larger firms may get better deals on new aircraft and have more flexible financing opportunities.

As international or domestic aviation fuel prices were not available, we use road gasoline prices, oil rents as a \% of GDP, and oil reserves, as proxy variables. The results for gasoline prices are similar for the simple and size-adjusted efficiency measures, with elasticities ranging from -0.09 to -0.132 for simple fleet fuel economy, and -0.087 to -0.11 for sizeadjusted fleet fuel economy, when we do not control for fleet model age and significant at the 1 or $5 \%$ level. In Table 6 , where we adjust fuel economy for the model age of the fleet, the coefficient on the price of gasoline is smaller and not significant at the $5 \%$ level. This shows that the response to variations in fuel price is largely addressed by varying the model age of planes employed. Our reported elasticities are somewhat smaller than Li et al. 's (2009) and Burke and Nishitateno (2013)'s results on car fleet fuel economy, who respectively find that a $1 \%$ increase in fuel prices results in a $0.2 \%$ improvement in fleet fuel economy, and to a $0.15-0.2 \%$ improvement in new vehicle fleet fuel economy. Of course, cars have a much lower lifespan than aircraft and as we only approximate jet fuel prices these estimates are likely subject to attenuation due to measurement error (Hausman, 2001). We also simultaneously control for oil rents as a percentage of GDP and for oil reserves in a country, both an indicator of fuel prices in general and of subsidies. We do not find the coefficient on either variable significant, after including gasoline prices.

Wages, which constitute one of the largest operating expenses of airlines were not found to be significant in any of the regressions in Tables 4 to 6 , though the sign of the effect is as expected. As we estimated wages for many airlines based observations for other airlines and GDP per capita, this is likely the result of measurement error. We would expect that airlines operating in poor vs. rich countries would show differences in their airline fleet fuel economy, although the generally higher interest rates in lower-income countries might be picking up this effect. 
Dependent variable: ln simple airline fleet fuel economy

\begin{tabular}{|c|c|c|c|c|}
\hline & $(1)$ & $(2)$ & (3) & (4) \\
\hline \multirow[t]{2}{*}{ ln total seats } & $-0.132 * * *$ & $-0.132 * * *$ & $-0.0249 * * *$ & $-0.0257 * * *$ \\
\hline & $(0.00921)$ & $(0.00940)$ & $(0.00725)$ & $(0.00733)$ \\
\hline \multirow[t]{2}{*}{ ln wage } & -0.0140 & -0.0112 & -0.0280 & -0.0240 \\
\hline & $(0.0237)$ & $(0.0240)$ & $(0.0186)$ & $(0.0183)$ \\
\hline \multirow[t]{2}{*}{ ln gasoline price } & $-0.0904 * *$ & $-0.132 * * *$ & $-0.0655^{* *}$ & $-0.0864 * *$ \\
\hline & $(0.0432)$ & $(0.0427)$ & $(0.0321)$ & $(0.0329)$ \\
\hline \multirow[t]{2}{*}{ ln oil reserves } & -0.000831 & & 0.0000740 & \\
\hline & $(0.00119)$ & & $(0.000958)$ & \\
\hline \multirow[t]{2}{*}{ ln oil rents } & & $-0.00703 *$ & & -0.000845 \\
\hline & & $(0.00412)$ & & $(0.00326)$ \\
\hline \multirow[t]{2}{*}{ In real interest rate } & $0.0282 * * *$ & $0.0276^{* *}$ & $0.0248 * * *$ & $0.0205 * *$ \\
\hline & $(0.0102)$ & $(0.0105)$ & $(0.00912)$ & $(0.0101)$ \\
\hline \multirow[t]{2}{*}{ In land area } & 0.0102 & $0.0165^{*}$ & $-0.0145^{*}$ & $-0.0137 *$ \\
\hline & $(0.0101)$ & $(0.00845)$ & $(0.00772)$ & $(0.00688)$ \\
\hline \multirow[t]{2}{*}{ In population } & -0.0168 & -0.0150 & 0.0141 & 0.0152 \\
\hline & $(0.0164)$ & $(0.0186)$ & $(0.0106)$ & $(0.0119)$ \\
\hline \multirow[t]{2}{*}{ In passengers } & $0.0315^{* *}$ & $0.0289^{*}$ & 0.0136 & 0.0129 \\
\hline & $(0.0141)$ & $(0.0146)$ & $(0.00901)$ & $(0.00929)$ \\
\hline \multirow[t]{2}{*}{ In average seats per airline } & & & $-0.276^{* * *}$ & $-0.273 * * *$ \\
\hline & & & $(0.0130)$ & $(0.0127)$ \\
\hline \multirow[t]{2}{*}{ In average age of fleet } & & & $0.192 * * *$ & $0.206^{* * *}$ \\
\hline & & & $(0.0543)$ & $(0.0556)$ \\
\hline \multirow[t]{2}{*}{ Europe and Central Asia } & $0.130 * * *$ & $0.138 * * *$ & $0.119 * * *$ & $0.124 * * *$ \\
\hline & $(0.0381)$ & $(0.0363)$ & $(0.0272)$ & $(0.0255)$ \\
\hline \multirow[t]{2}{*}{ Latin America \& Caribbean } & $0.0935^{* *}$ & $0.0952 * *$ & 0.0217 & 0.0272 \\
\hline & $(0.0386)$ & $(0.0397)$ & $(0.0283)$ & $(0.0279)$ \\
\hline \multirow[t]{2}{*}{ Middle East \& North Africa } & $-0.130 * *$ & $-0.128 * *$ & -0.0569 & -0.0616 \\
\hline & $(0.0561)$ & $(0.0576)$ & $(0.0428)$ & $(0.0456)$ \\
\hline \multirow[t]{2}{*}{ North America } & $0.0862 *$ & $0.0803 * *$ & 0.0380 & 0.0290 \\
\hline & $(0.0440)$ & $(0.0402)$ & $(0.0364)$ & $(0.0315)$ \\
\hline \multirow[t]{2}{*}{ South Asia } & -0.0564 & -0.0677 & $-0.0876^{* *}$ & $-0.0927 * *$ \\
\hline & $(0.0525)$ & $(0.0634)$ & $(0.0423)$ & $(0.0456)$ \\
\hline \multirow[t]{2}{*}{ Sub-Saharan Africa } & 0.0503 & 0.00115 & -0.0110 & -0.0376 \\
\hline & $(0.0543)$ & $(0.0557)$ & $(0.0419)$ & $(0.0441)$ \\
\hline \multirow[t]{2}{*}{ Constant } & $2.089 * * *$ & $1.964 * * *$ & $2.248 * * *$ & $2.138 * * *$ \\
\hline & $(0.306)$ & $(0.371)$ & $(0.337)$ & $(0.372)$ \\
\hline $\mathrm{N}$ & 890 & 852 & 890 & 852 \\
\hline adj. R-sq & 0.375 & 0.378 & 0.560 & 0.564 \\
\hline
\end{tabular}

Robust, country clustered standard errors in parentheses

$* \mathrm{p}<0.10, * * \mathrm{p}<0.05, * * * \mathrm{p}<0.01$

Table 4: Determinants of simple fleet fuel economy. The regional dummy omitted was East Asia and the Pacific. Regressions 3 and 4 do not control for average seats or the average age of the fleet. 
Dependent variable: Ln size adjusted airline fleet fuel economy

\begin{tabular}{|c|c|c|c|c|}
\hline & (1) & (2) & (3) & (4) \\
\hline \multirow[t]{2}{*}{ In total seats } & $-0.0375 * * *$ & $-0.0380 * * *$ & $-0.0180 * *$ & $-0.0177 * *$ \\
\hline & $(0.00658)$ & $(0.00672)$ & $(0.00766)$ & $(0.00781)$ \\
\hline \multirow[t]{2}{*}{ ln wage } & -0.0262 & -0.0243 & -0.0251 & -0.0219 \\
\hline & $(0.0194)$ & $(0.0198)$ & $(0.0181)$ & $(0.0181)$ \\
\hline \multirow[t]{2}{*}{ ln gasoline price } & $-0.0870 * *$ & $-0.111 * * *$ & $-0.0660 * *$ & $-0.0856^{* *}$ \\
\hline & $(0.0365)$ & $(0.0376)$ & $(0.0321)$ & $(0.0331)$ \\
\hline \multirow[t]{2}{*}{ ln oil reserves } & 0.000144 & & 0.000222 & \\
\hline & $(0.000941)$ & & $(0.000936)$ & \\
\hline \multirow[t]{2}{*}{ ln oil rents } & & -0.00143 & & -0.000314 \\
\hline & & $(0.00333)$ & & $(0.00310)$ \\
\hline \multirow[t]{2}{*}{ In real interest rate } & $0.0287 * * *$ & $0.0242 * *$ & $0.0246^{* * *}$ & $0.0200 * *$ \\
\hline & $(0.00912)$ & $(0.0100)$ & $(0.00907)$ & $(0.0100)$ \\
\hline \multirow[t]{2}{*}{ ln land area } & -0.0105 & -0.00727 & $-0.0132 *$ & $-0.0125^{*}$ \\
\hline & $(0.00814)$ & $(0.00711)$ & $(0.00753)$ & $(0.00655)$ \\
\hline \multirow[t]{2}{*}{ In population } & 0.00783 & 0.00715 & 0.0137 & 0.0141 \\
\hline & $(0.0119)$ & $(0.0140)$ & $(0.0107)$ & $(0.0121)$ \\
\hline \multirow[t]{2}{*}{ In passengers } & $0.0164 *$ & 0.0150 & 0.0117 & 0.0110 \\
\hline & $(0.00900)$ & $(0.00933)$ & $(0.00906)$ & $(0.00934)$ \\
\hline \multirow[t]{2}{*}{ In average age of fleet } & & & $0.211 * * *$ & $0.224 * * *$ \\
\hline & & & $(0.0547)$ & $(0.0560)$ \\
\hline \multirow[t]{2}{*}{ Europe and Central Asia } & $0.129 * * *$ & $0.134 * * *$ & $0.108 * * *$ & $0.113 * * *$ \\
\hline & $(0.0328)$ & $(0.0314)$ & $(0.0273)$ & $(0.0256)$ \\
\hline \multirow[t]{2}{*}{ Latin America \& Caribbean } & $0.0538 *$ & $0.0592 *$ & 0.0198 & 0.0244 \\
\hline & $(0.0310)$ & $(0.0312)$ & $(0.0287)$ & $(0.0283)$ \\
\hline \multirow[t]{2}{*}{ Middle East \& North Africa } & -0.0654 & -0.0696 & -0.0595 & -0.0641 \\
\hline & $(0.0465)$ & $(0.0505)$ & $(0.0433)$ & $(0.0464)$ \\
\hline \multirow[t]{2}{*}{ North America } & 0.0545 & 0.0445 & 0.0401 & 0.0293 \\
\hline & $(0.0407)$ & $(0.0371)$ & $(0.0364)$ & $(0.0315)$ \\
\hline \multirow[t]{2}{*}{ South Asia } & $-0.0861 * *$ & $-0.0844 *$ & $-0.0909 * *$ & $-0.0915^{*}$ \\
\hline & $(0.0420)$ & $(0.0480)$ & $(0.0434)$ & $(0.0468)$ \\
\hline \multirow[t]{2}{*}{ Sub-Saharan Africa } & 0.00608 & -0.0205 & -0.00881 & -0.0348 \\
\hline & $(0.0420)$ & $(0.0456)$ & $(0.0398)$ & $(0.0407)$ \\
\hline \multirow[t]{2}{*}{ Constant } & $1.589 * * *$ & $1.572 * * *$ & $0.782 * *$ & $0.709 *$ \\
\hline & $(0.261)$ & $(0.325)$ & $(0.327)$ & $(0.363)$ \\
\hline $\mathrm{N}$ & 890 & 852 & 890 & 852 \\
\hline adj. R-sq & 0.086 & 0.091 & 0.126 & 0.136 \\
\hline
\end{tabular}

Robust, country clustered standard errors in parentheses

$* \mathrm{p}<0.10, * * \mathrm{p}<0.05, * * * \mathrm{p}<0.01$

Table 5: Determinants of size adjusted fleet fuel economy. The regional dummy omitted was East Asia and the Pacific. Regressions 3 and 4 do not control for the average age of the fleet. 
Dependent variable: $\ln$ size and age adjusted airline fleet fuel economy

\begin{tabular}{|c|c|c|}
\hline & (1) & (2) \\
\hline \multirow[t]{2}{*}{ ln total seats } & $-0.0248 * * *$ & $-0.0255^{* * *}$ \\
\hline & $(0.00517)$ & $(0.00520)$ \\
\hline \multirow[t]{2}{*}{ ln wage } & -0.0107 & -0.00849 \\
\hline & $(0.0178)$ & $(0.0177)$ \\
\hline \multirow[t]{2}{*}{ ln gasoline price } & -0.0202 & $-0.0476^{*}$ \\
\hline & $(0.0293)$ & $(0.0284)$ \\
\hline \multirow[t]{2}{*}{ ln oil reserves } & -0.000170 & \\
\hline & $(0.000974)$ & \\
\hline \multirow[t]{2}{*}{ ln oil rents } & & -0.000133 \\
\hline & & $(0.00311)$ \\
\hline \multirow[t]{2}{*}{ ln real interest rate } & $0.0325 * * *$ & $0.0254 * * *$ \\
\hline & $(0.00836)$ & $(0.00872)$ \\
\hline \multirow[t]{2}{*}{ ln land area } & $-0.0153 * *$ & $-0.0161 * *$ \\
\hline & $(0.00692)$ & $(0.00618)$ \\
\hline \multirow[t]{2}{*}{ In population } & $0.0195^{*}$ & 0.0181 \\
\hline & $(0.0115)$ & $(0.0125)$ \\
\hline \multirow[t]{2}{*}{ ln passengers } & 0.00690 & 0.00666 \\
\hline & $(0.00950)$ & $(0.00960)$ \\
\hline \multirow[t]{2}{*}{ Europe and Central Asia } & $0.103 * * *$ & $0.106 * * *$ \\
\hline & $(0.0261)$ & $(0.0244)$ \\
\hline \multirow[t]{2}{*}{ Latin America \& Caribbean } & 0.0350 & 0.0409 \\
\hline & $(0.0282)$ & $(0.0272)$ \\
\hline \multirow[t]{2}{*}{ Middle East \& North Africa } & -0.0379 & -0.0541 \\
\hline & $(0.0388)$ & $(0.0411)$ \\
\hline \multirow[t]{2}{*}{ North America } & 0.0410 & 0.0347 \\
\hline & $(0.0336)$ & $(0.0269)$ \\
\hline \multirow[t]{2}{*}{ South Asia } & $-0.0929 *$ & -0.0882 \\
\hline & $(0.0525)$ & $(0.0566)$ \\
\hline \multirow[t]{2}{*}{ Sub-Saharan Africa } & -0.0138 & -0.0413 \\
\hline & $(0.0413)$ & $(0.0427)$ \\
\hline \multirow[t]{2}{*}{ Constant } & $1.345^{* * *}$ & $1.378 * * *$ \\
\hline & $(0.248)$ & $(0.291)$ \\
\hline $\mathrm{N}$ & 890 & 852 \\
\hline adj. R-sq & 0.040 & 0.044 \\
\hline
\end{tabular}

Table 6: Determinants of size and age adjusted fleet fuel economy. The regional dummy omitted was East Asia and the Pacific. Regressions 3 and 4 were carried out with country clustered standard errors. 


\begin{tabular}{|c|c|c|c|c|c|c|}
\hline \multirow[t]{2}{*}{ Dependent Variable: } & \multicolumn{2}{|c|}{$\begin{array}{l}\text { In simple airline fleet } \\
\text { fuel economy }\end{array}$} & \multicolumn{2}{|c|}{$\begin{array}{l}\text { In size adjusted airline } \\
\text { fleet fuel economy }\end{array}$} & \multicolumn{2}{|c|}{$\begin{array}{l}\text { airline fleet fuel } \\
\text { economy }\end{array}$} \\
\hline & (1) & (2) & (3) & (4) & (5) & (6) \\
\hline & - & - & & & & \\
\hline \multirow[t]{2}{*}{ ln total seats } & $0.0856^{* * *}$ & $0.0856^{* * *}$ & $-0.0141 * *$ & $-0.0145^{* *}$ & -0.00103 & -0.00143 \\
\hline & $(0.0110)$ & $(0.0111)$ & $(0.00710)$ & $(0.00719)$ & $(0.00579)$ & $(0.00582)$ \\
\hline \multirow[t]{3}{*}{ ln wage } & -0.0239 & -0.0236 & -0.00432 & -0.00594 & 0.0219 & 0.0219 \\
\hline & $(0.0274)$ & $(0.0284)$ & $(0.0196)$ & $(0.0202)$ & $(0.0180)$ & $(0.0186)$ \\
\hline & - & & - & - & & - \\
\hline \multirow[t]{2}{*}{ ln gasoline price } & $0.0752 * * *$ & $-0.104 * * *$ & $0.0809^{* * *}$ & $0.0932 * * *$ & $-0.0559 * *$ & $0.0669 * * *$ \\
\hline & $(0.0205)$ & $(0.0241)$ & $(0.0228)$ & $(0.0250)$ & $(0.0225)$ & $(0.0237)$ \\
\hline \multirow[t]{2}{*}{ In oil reserves } & $-0.00126^{*}$ & & -0.000444 & & -0.000394 & \\
\hline & $(0.000750)$ & & $(0.000723)$ & & $(0.000761)$ & \\
\hline \multirow[t]{2}{*}{ ln oil rents } & & $-0.00660^{*}$ & & -0.00167 & & -0.00127 \\
\hline & & $(0.00351)$ & & $(0.00310)$ & & $(0.00281)$ \\
\hline \multirow[t]{2}{*}{ In real interest rate } & $0.0105^{*}$ & $0.0116^{* *}$ & 0.0118 & 0.0107 & $0.0154 * *$ & $0.0141 *$ \\
\hline & $(0.00574)$ & $(0.00564)$ & $(0.00758)$ & $(0.00774)$ & $(0.00671)$ & $(0.00717)$ \\
\hline \multirow[t]{2}{*}{ In land area } & 0.00893 & $0.0133 * *$ & -0.00632 & -0.00294 & -0.00882 & -0.00758 \\
\hline & $(0.00640)$ & $(0.00573)$ & $(0.00585)$ & $(0.00461)$ & $(0.00537)$ & $(0.00501)$ \\
\hline \multirow[t]{2}{*}{ In population } & $-0.0231^{*}$ & -0.0205 & -0.000428 & -0.000109 & 0.00892 & 0.00935 \\
\hline & $(0.0134)$ & $(0.0147)$ & $(0.0102)$ & $(0.0112)$ & $(0.0100)$ & $(0.0110)$ \\
\hline \multirow[t]{2}{*}{ ln passengers } & $0.0346^{* * *}$ & $0.0322 * *$ & 0.00837 & 0.00654 & -0.00240 & -0.00274 \\
\hline & $(0.0131)$ & $(0.0135)$ & $(0.00995)$ & $(0.0100)$ & $(0.00970)$ & $(0.00990)$ \\
\hline \multirow[t]{2}{*}{ Europe and Central Asia } & $0.0692 * * *$ & $0.0769 * * *$ & $0.0584 * * *$ & $0.0666^{* * *}$ & $0.0401 * *$ & $0.0444 * *$ \\
\hline & $(0.0210)$ & $(0.0212)$ & $(0.0211)$ & $(0.0198)$ & $(0.0201)$ & $(0.0203)$ \\
\hline \multicolumn{7}{|l|}{ Latin America \& } \\
\hline \multirow[t]{2}{*}{ Caribbean } & $0.0563 * *$ & $0.0605^{* *}$ & 0.00121 & 0.00612 & -0.00893 & -0.00451 \\
\hline & $(0.0282)$ & $(0.0300)$ & $(0.0234)$ & $(0.0238)$ & $(0.0222)$ & $(0.0225)$ \\
\hline Middle East \& North & - & & & & & \\
\hline \multirow[t]{2}{*}{ Africa } & $0.0785^{* * *}$ & $-0.0738 * *$ & $-0.0611^{*}$ & -0.0562 & -0.0472 & -0.0462 \\
\hline & $(0.0285)$ & $(0.0300)$ & $(0.0324)$ & $(0.0351)$ & $(0.0306)$ & $(0.0332)$ \\
\hline \multirow[t]{3}{*}{ North America } & $0.0504^{*}$ & $0.0603 * *$ & -0.00243 & 0.00357 & -0.0274 & -0.0246 \\
\hline & $(0.0295)$ & $(0.0288)$ & $(0.0274)$ & $(0.0255)$ & $(0.0257)$ & $(0.0239)$ \\
\hline & & & - & & - & \\
\hline \multirow[t]{2}{*}{ South Asia } & $-0.0615^{* *}$ & $-0.0722 * *$ & $0.0893^{* * *}$ & $-0.0884 * *$ & $0.0894 * * *$ & $-0.0895 * *$ \\
\hline & $(0.0298)$ & $(0.0335)$ & $(0.0335)$ & $(0.0361)$ & $(0.0315)$ & $(0.0342)$ \\
\hline \multirow[t]{2}{*}{ Sub-Saharan Africa } & $0.0874 * *$ & 0.0607 & 0.0312 & 0.0217 & 0.0184 & 0.00616 \\
\hline & $(0.0415)$ & $(0.0437)$ & $(0.0346)$ & $(0.0384)$ & $(0.0351)$ & $(0.0385)$ \\
\hline \multirow[t]{2}{*}{ Constant } & $1.979 * * *$ & $1.876^{* * *}$ & $1.487 * * *$ & $1.473 * * *$ & $1.161 * * *$ & $1.137 * * *$ \\
\hline & $(0.295)$ & $(0.326)$ & $(0.237)$ & $(0.267)$ & $(0.222)$ & $(0.254)$ \\
\hline $\mathrm{N}$ & 890 & 852 & 890 & 852 & 890 & 852 \\
\hline adj. R-sq & 0.305 & 0.303 & 0.026 & 0.029 & 0.009 & 0.008 \\
\hline
\end{tabular}

Table 7: Determinants of fleet fuel economy: Weighted least squares estimates with the square root of total seats used as weights. 
We find that real interest rates are significant at the $1 \%$ to $5 \%$ level in all specifications, and have a positive coefficient as expected. This means that a $1 \%$ increase in interest rates (for example from 1.0 to $1.01 \%$ in levels), will result in the worsening of long-run fleet fuel economy between 0.02 to $0.033 \%$. Higher interest rates not only mean a higher cost of capital for purchasing aircraft, but are also incorporated in lease-rates, effectively increasing the cost of renting an aircraft. Therefore, higher interest rates are likely to result in less investment into newer, efficient technologies.

Finally, we consider the environmental variables. We find that greater land area is associated with better fuel economy only when we adjust or control for model age. This indicates that even though we control for the size of the aircraft and the size of the airline, airlines based in larger countries fly more technically efficient aircraft. Population and passenger numbers were not found to be a significant driver of fleet fuel economy.

We find compared to the base region of East Asia and the Pacific that Europe and Central Asia has significantly worse fleet fuel economy. This result is remarkably robust in all three specifications, and is not only driven by airlines in Russia and the USSR successor states, but also by airlines in the European Union. The results are not attributable to the age of the fleets or to the size of the aircraft, but potentially to different technology used in planes of the same age and seat size. These planes are often manufactured by smaller companies. Compared to the base region, South-Asia also shows significantly higher efficiency in some specifications including our central estimates in Columns 3 and 4 in Table 5. In the simple fleet fuel economy regressions without the fleet age and average seat size controls, a number of regional dummies are significant. Most of these inferences disappear however, once we adjust or control for seat size and age.

We present weighted least squares estimates in Table 7 focusing on the size adjusted estimates in Columns 3 and 4. These are broadly similar to those in Table 5. The returns to scale effect is smaller here, the dummy for Europe and Central Asia has a smaller effect, and the coefficient of the South Asia dummy is much more significant.

\section{Conclusions and Policy Implications}

In this paper, we investigated the impact of plane size and age, fuel prices, capital costs, wages and airline size on technically achievable fleet fuel economy. We constructed a dataset 
from plane-level data for 1267 airlines in 2015. Newer and bigger aircraft are more efficient. We find that, ceteris paribus, larger airlines - as measured by total number of seats - have higher fleet fuel economy. This suggests that there are economies of scale in fuel efficiency choice. Larger airlines not only fly larger, and thus more fuel-efficient planes, but they use more fuel-efficient aircraft independent of the size (and also model age) of aircraft. One of the explanations is that larger airlines potentially have better access to financing or lower capital costs and are willing to invest in more fuel-efficient aircraft. We also find that the elasticity of fleet fuel economy with respect to the price of fuel is between -0.07 to -0.13 , depending on specification, where a negative sign indicates an improvement in fleet fuel economy with higher fuel prices. This value is only a little lower than previous studies have reported for road vehicle fleet fuel economy. Higher interest rates are, on the other hand, associated with worse fleet fuel economy. Wages were not found to have a significant effect. We find that, despite a wide range of controls, some regional differences persist, which are independent of the age or the size of the aircraft or the other controls. These differences are best explained by the evolution of different technological designs for aircraft of the same size and age throughout the world.

Looking into the future, our findings confirm that airline fleet fuel economy is significantly though very inelastically responsive to changes in fuel prices as well as credit costs and availability. The policy implications of these findings are twofold: We see that higher taxes on domestic aviation fuel, the removal of fuel subsidies, or taxes on aircraft GHG emissions would in fact result in some improvement of fleet fuel economy through change in the composition of the fleet. Our estimate of the fuel economy elasticity treats the current price of aircraft of varying fuel efficiency as an implicit given. Induced technical change could increase the long-run response by lowering the cost of fuel-efficient aircraft. On the other hand, there could also be some leakage (Jacobsen and van Benthem, 2015) if global fuel price increases lowered the price of less fuel-efficient aircraft.

As international agreements on aircraft emissions standards are consistently delayed, and the introduction of carbon pricing has been limited to regional initiatives, the removal of fuel subsidies would seem the most plausible course of action. While some states may keep subsidizing fuel in order to support their national flagship carriers, we have seen several successful examples of fossil fuel subsidy removal. Long-run efficiency gains may translate to long-run profits for firms, and the economy, result in cleaner skies and a pathway to emission reductions of the aviation sector. 


\section{References}

Adrangi, B., Gritta, R. D., Raffiee, K. (2014). "Dynamic interdependence in jet fuel prices and air carrier revenues", Atlantic Economic Journal 42: 473-474.

Alcott, H. Wozny, N. (2014). "Gasoline prices, fuel economy and the energy paradox", The Review of Economics and Statistics 96(5): 779-795.

Anger, A. Koehler, J. (2010). "Including aviation emissions in the EU ETS: much ado about nothing? A review", Transport Policy 17(1): 38-46.

Babikian, R., Lukachko, S. P., Waitz, I. A. (2002). "The historical fuel efficiency characteristics of regional aircraft from technological, operational, and cost perspectives", Journal of Air Transport Management 8: 389-400.

Barreto L., Kemp, R. (2008). "Inclusion of technology diffusion in energy-system models: some gaps and needs", Journal of Cleaner Production 16S1: 95-101.

Benmelech, E., Bergman, N. (2011). "Vintage capital and creditor protection", Journal of Financial Economics 99: 308-332.

Berry, S. Jia, P. (2010). "Tracing the woes: an empirical analysis of the airline industry", American Economic Journal: Microeconomics 2: 1-43.

Borenstein, S. (2011). "Why can't US airlines make money?" American Economic Review 101(3): 233-237.Burke, P. J. (2013). The national-level energy ladder and its carbon implications, Environment and Development Economics 18(4): 484-503.

Burke P. J., Nishitateno, S. (2013). “Gasoline prices, gasoline consumption, and new-vehicle fuel economy: Evidence for a large sample of countries”, Energy Economics 36: 363-370.

Caves, D. W. Christensen, L. R., Tretheway, M. W. (1984). "Economies of density versus economies of scale - why trunk and local-service airline costs differ", Rand Journal Of Economics 15(4): 471-489.

Coelli, T., Perelman, S., Romano, E. (1999). “Accounting for environmental influences in stochastic frontier models: With application to international airlines", Journal of Productivity Analysis 11(3): 251-273.

Economist, The (2012). "Buy or rent?”, http://www.economist.com/node/21543195, print 
edition: Jan 21", 2012.

EASA/EEA/EUROCONTROL (2016). European Aviation Environmental Report, DOI: 10.1007/s11293-013-9388-9, ISBN: 978-92-9210-197-8

Eisfeldt, A., Rampini, A. (2006). "Capital reallocation and liquidity", Journal of Monetary Economics 53(3): 369-399.

ECB (2017). European Central Bank data: Corporates' cost of borrowing,_\%: https://sdwwsrest.ecb.europa.eu/service/data/MIR/M.AT+BE+CY+DE+EE+ES+FI+FR+GR+IE+IT+LT $+\mathrm{LU}+\mathrm{LV}+\mathrm{MT}+\mathrm{NL}+\mathrm{PT}+\mathrm{SI}+\mathrm{SK}+\mathrm{U} 2 . B . A 2 I . A M . R . A .2240 . E U R . N ?$ startPeriod=2003

Flightglobal (2015). World Airliner Census 2015. https://www.flightglobal.com/asset/3480

GAO- United States Government Accountability Office (2014). Report to Congressional Committees, Aviation, Impact of Fuel Price Increases on the Aviation Industry, GAO-14331.

Gavazza, A. (2011). "Leasing and secondary markets: theory and evidence from commercial aircraft", Journal of Political Economy 119(2): 325-377.

Gillen, D. W., Oum, T. H., Tretheway, M.W. (1990). "Airline cost structure and policy implications: a multi-product approach for Canadian airlines", Journal of Transport Economics and Policy 24(1): 9-34.

Greve, H. R., Seidel, M-D. L. (2015). "The thin red line between success and failure: Path dependence in the diffusion of innovative production technologies", Strategic Management Journal 36: 475-496.

Hausman, J. (2001). "Mismeasured variables in econometric analysis: problems from the right and problems from the left", Journal of Economic Perspectives 54(4): 57-67.

ICAO - International Civil Aviation Organization (2016). Assembly $-39^{\text {th }}$ Session, Agenda Item 22: Environmental Protection - International Aviation and Climate Change - Policy, Standardization and Implementation Support, Working Paper: A39-WP/207, EX/77, 18/8/16 IEA - International Energy Agency (2009). Transport, Energy and CO2, moving towards sustainability, IEA/OECD 2009, (61 200925 1P1) ISBN: 978-92-64-07316-6.

IEA (2014). World Energy Outlook 2014, International Energy Agency. 
IEA (2016). World Energy Outlook 2016, International Energy Agency.

Inglada, V, Rey, B, Rodriguez-Alvarez, A, Coto-Millan, P. (2006). "Liberalisation and efficiency in international air transport", Transportation Research Part A-Policy and Practice 40(2): 95-105.

Jacobsen, M.R., van Benthem, A.A. (2015). "Vehicle Scrappage and Gasoline Policy", American Economic Review 105(3): 1312-1338

Jaffe, A., Stavins, R. (1994). "The energy paradox and the diffusion of conservation technology", Resource and Energy Economics 16: 91-122.

Kahn, M. E., Nickelsburg, J. (2016). „An economic analysis of U.S. airline fuel economy dynamics from 1991 to 2015”, NBER Working Paper 22830.

Keen, M. Strand, J. (2007). “Indirect taxes on international aviation”, Fiscal Studies 28(1): 141.

Klier, T., Linn, J. (2010). "The price of gasoline and new vehicle fuel economy: evidence from monthly sales data", American Economic Journal: Economic Policy 2: 134-153.

Lee, J. J., Lukachko, S. P., Waitz, I. A., Schafer, A. (2001). "Historical and future trends in aircraft performance, cost, and emissions", Annual Review of Energy and the Environment 26: $167-200$.

Lee, J. J. (2010). "Can we accelerate the improvement of energy efficiency in aircraft systems"? Energy Conversion and Management 51: 189-196.

Li, S., Timmins, C., von Haefen R. H. (2009). "How do gasoline prices affect fleet fuel economy?" American Economic Journal: Economic Policy 1(2): 113-137.

Murphy, F., Li, N. Murphy, B., Cummins, M. (2013). "The link between jet fuel prices, carbon credits and airline firm value", Journal of Energy Markets 6(2): 83-97.

Naumann, N., Suhl, L. (2013). "How does fuel price uncertainty affect strategic airline planning?" Operational Research 13 (3): 343-362.

Nava, C. R., Meleo, L. Cassetta, E. Morelli, G. (2017). "The impact of the EU-ETS on the aviation sector: competitive effects of abatement efforts by airlines", Department of 
Economics and Statistics “Cognetti de Martiis” Campus, Working Paper 10/17.

http://econpapers.repec.org/paper/utodipeco/201710.htm

Oum, T. H., Yu, C. Y. (1998). “Cost competitiveness of major airlines: An international comparison", Transportation Research Part A-Policy and Practice 32(6): 407-422.

Peeters, P. M., Middel, J., Hoolhorst, A. (2005). "Fuel efficiency of commercial aircraft An overview of historical and future trends", National Aerospace Laboratory (NLR) Report:

NLR-CR-2005-669.

Romano, J. P., Wolf, M. (2017). "Resurrecting weighted least squares”, Journal of Econometrics 197: 1-19.

Rosskopf, M., Lehner, S., Gollnick, V. (2014). "Economic -environmental trade-offs in longterm airline fleet planning", Journal of Air Transport Management 34: 109-115.

Scheelhaase J., Grimme, W., Schaefer M. (2010). "The inclusion of aviation in the EU greenhouse gas emissions trading scheme - impacts on competition between European and non-European network airlines", Transportation Research Part D: Transport and Environment 15(1): 14-25.

Sims R., Schaeffer R., Creutzig, F., Cruz-Núñez, X., D’Agosto, M., Dimitriu, D., Figueroa Meza, M. J., Fulton L., Kobayashi, S., Lah, O., McKinnon, A., Newman, P., Ouyang, M., Schauer, J. J., Sperling, D., Tiwari, G. (2014). Transport. In: Climate Change 2014:

Mitigation of Climate Change. Contribution of Working Group III to the Fifth Assessment Report of the Intergovernmental Panel on Climate Change [Edenhofer, O., Pichs-Madruga, R., Sokona, Y., Farahani, E., Kadner, S., Seyboth, K., Adler, A., Baum, I., Brunner, S., Eickemeier, P., Kriemann, B., Savolainen, J., Schlömer, S., von Stechow, C., Zwickel, T., Minx, J. C. (eds.)]. Cambridge University Press, Cambridge, United Kingdom and New York, NY, USA.

Verdolini, E., Galeotti, M. (2011). "At home and abroad: an empirical analysis of innovation and diffusion in energy technologies", Journal of Environmental Economics and Management 61(2): 119-134.

Vespermann, J., Wittner, A. (2011). "Financial, ecological and managerial impacts of emission trading schemes: the case of Lufthansa", Business Strategy and the Environment 20(3): 174-191. 
World Bank (2017). World Development Indicators. http://data.worldbank.org/datacatalog/world-development-indicators

Zou, B., Elke, M., Hansen, M., Kafle, N. (2014). "Evaluating air carrier fuel efficiency in the US airline industry", Transportation Research Part A 59: 306-330.

Zou, B., Kwan, I., Hansen, M., Rutherford, D., Kafle, N. (2016). Airline Fuel Efficiency:

Assessment Methodologies and Applications in the U.S. Domestic Airline Industry, Advances in Airline Economics, edited by Peoples, J., Bitzan, J., Emerald Group Publishing.

\section{Appendices:}

- List of aircraft types used and technical data

- Sources of technical information 


\section{Appendix 1: Technical Data}

Aircraft Model

AIRBUS A300 B1

AIRBUS A300 B4600

AIRBUS A310

AIRBUS A318

AIRBUS A319

AIRBUS A320

AIRBUS A321

AIRBUS A330 200

AIRBUS A330 300

AIRBUS A340 200

AIRBUS A340 300

AIRBUS A340 500

AIRBUS A340 600

AIRBUS A350 900

AIRBUS A380

ANTONOV AN-72/74

ANTONOV AN140

ANTONOV AN148

ANTONOV AN158

ANTONOV AN24

ANTONOV AN26

ANTONOV AN28

ANTONOV AN3

ANTONOV AN38

ATR 42300

ATR 42400

ATR 42500

ATR 42600

ATR 72200

ATR 72210

ATR 72500

ATR 72600

BAE (HS) 748

BAE ATP

BAE AVRO 146RJ 200

BAE AVRO 146RJ 300

BAE BAE146 100

BAE JETSTREAM 31

BAE JETSTREAM 41

BAE SYSTEMS AVRO RJ 100

BAE SYSTEMS AVRO RJ 85

BEECHCRAFT 1900C

BEECHCRAFT 1900D
Seat

$$
\begin{array}{r}
2 \\
294 \\
233 \\
1 \\
1 \\
1 \\
185 \\
2 \\
2 \\
34
\end{array}
$$

277

293

326

325

544

60

52

77.5

94

50

40

17

12

27

48

48

48

48

66

66

68

70

58

72

109

100

70

19

29

128

112

19

19
Fuel

Capacity

43,478

62,000

61,070

24,210

30,190

27,200

30,030

139,090

139,090

155,040

140,640

215,260

195,520

141,000

320,000

13,075

5,627

8,328

7,595

6,522

6,875

1,957

1,624

2,860

5,754

5,754

5,754

5,754

6,394

6,394

6,394

6,394

6,546

6,360

11,728

11,728

11,728

1,850

3,300

11,701

11,701

2,520

2,520
Maximum First

Range Flight

$2,222 \quad 1972$

$6,670 \quad 1983$

$6,800 \quad 1982$

$5,750 \quad 2002$

$6,950 \quad 1995$

$6,100 \quad 1987$

$5,950 \quad 1993$

$13,450 \quad 1997$

$11,750 \quad 1992$

$12,408 \quad 1992$

$13,500 \quad 1991$

$16,668 \quad 2002$

$14,450 \quad 2002$

$15,000 \quad 2013$

$15,200 \quad 2005$

$2,975 \quad 1977$

2,300 $\quad 1997$

$3,367 \quad 2004$

$2,800 \quad 2010$

$2,400 \quad 1960$

$2,550 \quad 1969$

$1,250 \quad 1969$

$1,200 \quad 1947$

$900 \quad 1994$

$845 \quad 1984$

$1,470 \quad 1995$

$1,326 \quad 1994$

$1,326 \quad 2010$

$1,615 \quad 1988$

$1,491 \quad 1988$

$1,454 \quad 1988$

$1,528 \quad 1988$

$1,715 \quad 1960$

$1,740 \quad 1969$

2,222 1984

2,222 1985

$2,174 \quad 1981$

$1,185 \quad 1982$

$1,263 \quad 1991$

$2,760 \quad 1992$

2,965 1992

$1,070 \quad 1982$

$2,500 \quad 1982$ 
BEECHCRAFT B99

BOEING 717200

BOEING 727100

BOEING 727200

BOEING 737200

BOEING 737300

BOEING 737400

BOEING 737500

BOEING 737600

BOEING 737700

BOEING 737800

BOEING 737900

BOEING 737 900ER

BOEING 747100

BOEING 747200

BOEING 747300

BOEING 747400

BOEING 7478

BOEING 747 SP

BOEING 757200

BOEING 757300

BOEING 767200

BOEING 767 200ER

BOEING 767300

BOEING 767 300ER

BOEING 767 400ER

BOEING 777 200ER

BOEING 777 200LR

BOEING 777300

BOEING 777 300ER

BOEING 7878

BOEING 7879

BOEING MD-11

BOMBARDIER CRJ 1000

BOMBARDIER CRJ100/200

BOMBARDIER CRJ700

BOMBARDIER CRJ900

BOMBARDIER DASH 8 Q100

BOMBARDIER DASH 8 Q200

BOMBARDIER DASH 8 Q300

BOMBARDIER DASH 8 Q400

CONVAIR 580

CONVAIR $640 *$

DE HAVILLAND CANADA DHC7

DE HAVILLAND CANADA TWIN

OTTER

$\begin{array}{rrrr}15 & 1,430 & 1,665 & 1966 \\ 117.5 & 13,904 & 2,408 & 1998 \\ 106 & 29,069 & 5,005 & 1963 \\ 118.5 & 30,620 & 4,021 & 1963 \\ 116.5 & 16,176 & 4,899 & 1967 \\ 138 & 20,102 & 2,300 & 1984 \\ 167.5 & 20,102 & 2,500 & 1988 \\ 128.5 & 20,102 & 3,400 & 1989 \\ 119 & 26,022 & 5,982 & 1998 \\ 138 & 26,022 & 6,112 & 1997 \\ 172 & 26,022 & 5,417 & 1997 \\ 183 & 26,022 & 5,052 & 2000 \\ 196 & 26,025 & 5,900 & 2006 \\ 423 & 178,700 & 8,556 & 1969 \\ 423 & 198,380 & 9,780 & 1970 \\ 496 & 198,380 & 10,360 & 1982 \\ 538 & 210,590 & 12,435 & 1988 \\ 467 & 243,400 & 14,800 & 2011 \\ 314 & 189,890 & 10,840 & 1975 \\ 212.5 & 42,680 & 5,550 & 1982 \\ 261 & 43,400 & 6,400 & 1998 \\ 253 & 58,902 & 9,401 & 1981 \\ 253 & 82,143 & 12,200 & 1984 \\ 280 & 63,216 & 9,700 & 1986 \\ 280 & 91,380 & 11,000 & 1986 \\ 326 & 91,370 & 10,400 & 1999 \\ 372.5 & 171,170 & 14,260 & 1996 \\ 370.5 & 181,280 & 17,370 & 2005 \\ 459 & 171,100 & 11,140 & 1997 \\ 457.5 & 181,200 & 12,995 & 2003 \\ 230 & 126,200 & 13,620 & 2009 \\ 290 & 126,370 & 14,140 & 2013 \\ 354 & 146,170 & 12,270 & 1990 \\ 100 & 11,114 & 3,004 & 2008 \\ 50 & 5,300 & 1,800 & 1991 \\ 72 & 10,990 & 2,650 & 1999 \\ 83 & 10,990 & 2,950 & 2001 \\ 38 & 3,160 & 1,900 & 1983 \\ 38 & 3,160 & 1,700 & 1983 \\ 53 & 3,160 & 1,500 & 1987 \\ 90 & 6,530 & 2,500 & 1998 \\ 56 & 7,950 & 1,750 & 1960 \\ 56 & 7,950 & 1,750 & 1960 \\ 50 & 5,757 & 1,296 & 1975 \\ 19 & 1,450 & 1,690 & 2010\end{array}$


DORNIER 228

DORNIER 328

DORNIER 328JET

EMBRAER 135 ER

EMBRAER 135 LR

EMBRAER 140 LR

EMBRAER 145 LR

EMBRAER 170 AR

EMBRAER 170 LR

EMBRAER $170 \mathrm{ST}$

EMBRAER 175 LR

EMBRAER 175 ST

EMBRAER 190 AR

EMBRAER 190 LR

EMBRAER 190 ST

EMBRAER 195 AR

EMBRAER 195 LR

EMBRAER 195 ST

EMBRAER EMB-110

BANDEIRANTE

EMBRAER EMB-120 BRASILIA

FAIRCHILD METRO/MERLIN

FOKKER 100

FOKKER 27

FOKKER 28

FOKKER 50

FOKKER 70

ILYUSHIN IL114

ILYUSHIN IL18

ILYUSHIN IL62

ILYUSHIN IL96

INDONESIAN AEROSPACE 212

LET L-410

MCDONNELL DOUGLAS DC10 10

MCDONNELL DOUGLAS DC8 43

MCDONNELL DOUGLAS DC9 10

MCDONNELL DOUGLAS DC9 30

MCDONNELL DOUGLAS DC9 50

MCDONNELL DOUGLAS MD81

MCDONNELL DOUGLAS MD82

MCDONNELL DOUGLAS MD83

MCDONNELL DOUGLAS MD87

MCDONNELL DOUGLAS MD88

MCDONNELL DOUGLAS MD90

NAMC YS1 1

SAAB 2000
19

33

32

37

37

44

50

72

72

72

82

82

105

105

105

112

112

112

19.5

30

19

109

44

65

50

79

64

120

162

267.5

21

19

327

177

80

112

132

142

156

156

126.5

156

162

62

50

\section{2,441}

4,290

8,040

5,336

6,480

6,480

6,396

11,625

11,625

11,625

11,625

11,625

16,153

16,153

16,153

16,153

16,153

16,153

1,670

3,325

2,450

13,360

5,069

9,640

5,140

13,360

8,360

23,700

105,300

150,400

2,000

1,675

82,376

88,552

13,980

13,900

16,100

22,129

22,100

26,350

22,100

26,350

22,130

7,270

5,980
1,037

1,150

1,700

2,409

3,243

3,058

2,873

3,982

3,889

3,334

3,982

3,241

4,445

3,426

4,074

4,260

3,704

4,537

2,000

1,750

2,000

3,100

2,593

2,957

3,000

3,470

1,000

7,100

6,700

7,500

740

1,040

3,704

5,713

1,055

2,200

1,850

2,575

3,800

4,600

4,400

4,600

4,400

1,100

2,100
1981

1991

1998

1998

1998

2000

1998

2002

2002

2002

2002

2003

2002

2002

2004

2002

2002

2004

1968

1983

1969

1986

1955

1967

1985

1993

1990

1957

1963

1988

1971

1969

1970

1958

1965

1965

1974

1979

1980

1984

1986

1987

1993

1962

1992 


$\begin{array}{lrrrr}\text { SAAB 340 } & 37 & 3,220 & 1,500 & 1983 \\ \text { SHORTS 330 } & 30 & 2,550 & 870 & 1974 \\ \text { SHORTS 360 } & 39 & 2,180 & 1,100 & 1981 \\ \text { SUKHOI SUPERJET 100 } & 94.5 & 13,135 & 3,050 & 2008 \\ \text { TUPOLEV TU134 } & 72 & 18,414 & 2,770 & 1963 \\ \text { TUPOLEV TU154 } & 155.5 & 47,000 & 2,780 & 1968 \\ \text { TUPOLEV TU204 } & 202 & 30,812 & 4,400 & 1989 \\ \text { XIAN MA60 } & 56 & 5,153 & 1,600 & 2000 \\ \text { YAKOVLEV YAK40 } & 31.5 & 5,665 & 1,200 & 1966 \\ \text { YAKOVLEV YAK42 } & 108 & 23,300 & 1,530 & 1975\end{array}$

Table A.1: Technical information of aircraft used in the dataset. Due to lack of data, the following substitutions were assumed: For Convair 640, data from Convair 590 was filled. For Embraer 145 LU, LI, EP, ER, EU, MP, and XR, the technical data of Embraer 145 LR was assigned. For Embraer 170 SU, the technical data of Embraer 170 ST was assigned, for Embraer 190 SE, Embraer 190 ST was used. The year of first flight was assumed as 2002 for Embraer 170 LR/AR ,175LR, 190 LR/AR, 195LR/AR. 


\section{Appendix 2}

Aircraft Model: A300 B1

Aircraft Version: B1

Seats: Average between single-class and three-class seating capacity.

Source: http://www.aerospaceweb.org/aircraft/jetliner/a300/

Fuel Capacity: Source: EASA (2016) pp.8

The original data was 34000 , but that was measurement was in $\mathrm{kg}$. We converted this number to litres assuming a volume mass of .782 kg/L (number given in EASA, 2016).

Maximum Range:

First Flight: Source: http://www.actforlibraries.org/all-about-the-a300-airbus/

\section{Aircraft Model: AIRBUS A300 B2}

Aircraft Version: 100

Seats: Source:

http://www.airbus.com/fileadmin/media_gallery/files/tech_data/AC/AC_A300_20091201.pdf

Fuel Capacity:

http://www.airbus.com/fileadmin/media_gallery/files/tech_data/AC/AC_A300_20091201.pdf

Maximum Range: http://www.actforlibraries.org/all-about-the-a300-airbus/

First Flight: http://www.airbus.com/newsevents/news-events-single/detail/the-first-airbus-settingnew-standards-together/

Aircraft Model: AIRBUS A300 B2

Aircraft Version: 200

Seats: Average between single-class and three-class seating capacity.

Source: http://www.airliners.net/aircraft-data/airbus-a300b2b4/17

Fuel Capacity:

Source: http://www.airbus.com/fileadmin/media_gallery/files/tech_data/AC/AC_A300_20091201.pdf

Maximum Range:

Range with maximum passengers and reserves.

Source: http://www.airliners.net/aircraft-data/airbus-a300b2b4/17

First Flight:

Source: https://en.wikipedia.org/wiki/Airbus_A300

Aircraft Model: AIRBUS A300 B4

Aircraft Version: 100

Seats: Average between single-class and three-class seating capacity.

Source: http://www.airliners.net/aircraft-data/airbus-a300b2b4/17

Fuel Capacity:

Source: http://www.airbus.com/fileadmin/media_gallery/files/tech_data/AC/AC_A300_20091201.pdf

Maximum Range: Source: https://en.wikipedia.org/wiki/Airbus_A300

First Flight: Source: https://en.wikipedia.org/wiki/Airbus_A300

Aircraft Model: AIRBUS A300 B4

Aircraft Version: 200

Seats: Average between single-class and two-class seating capacity.

Source: https://www.airlines-inform.com/commercial-aircraft/Airbus-A300.html

Fuel Capacity:

Source: http://www.airbus.com/fileadmin/media_gallery/files/tech_data/AC/AC_A300_20091201.pdf

Maximum Range: Assuming maximum number of passengers and reserves.

Source: http://www.airliners.net/aircraft-data/airbus-a300b2b4/17

First Flight: Source: https://en.wikipedia.org/wiki/Airbus_A300 
Aircraft Model: AIRBUS A300 B4

Aircraft Version: 600

Seats: Seating information is for 600R: Seating capacity usually remains the same as the base when a long-range version is created.

Source: https://www.airlines-inform.com/commercial-aircraft/Airbus-A300.html

Fuel Capacity: Hyperlinked source (pp. 18) specifies 62000-76400 1 depending on the engine used. Maximum Range:

First Flight: http://www.airbus.com/company/history/the-interactive-timeline/

Aircraft Model: AIRBUS A310

Aircraft Version: 200

Seats: Average between single-class and three-class seating capacity.

Source: https://www.airlines-inform.com/commercial-aircraft/Airbus-A310.html

Fuel Capacity: Standard fuel capacity.

Source: https://www.airlines-inform.com/commercial-aircraft/Airbus-A310.html

Maximum Range: Assuming maximum payload.

Source: https://www.airlines-inform.com/commercial-aircraft/Airbus-A310.html

First Flight: Source: http://www.airbus.com/presscentre/pressreleases/press-releasedetail/detail/a310-200-first-flight/

Aircraft Model: AIRBUS A310

Aircraft Version: 300

Seats: Average between single-class and three-class seating capacity.

Source: https://www.airlines-inform.com/commercial-aircraft/Airbus-A310.html

Fuel Capacity: Standard fuel capacity.

Source: https://www.airlines-inform.com/commercial-aircraft/Airbus-A310.html

Maximum Range: Assuming maximum payload.

Source: https://www.airlines-inform.com/commercial-aircraft/Airbus-A310.html

First Flight: http:/www.airbus.com/company/history/the-interactive-timeline/

Aircraft Model: AIRBUS A318

Aircraft Version: A318

Seats: Typical seating capacity. Source: Airbus Family booklet (2016)

Fuel Capacity: Source: Airbus Family booklet (2016)

Maximum Range: Source: Airbus Family booklet (2016)

First Flight: Source: http://www.airbus.com/presscentre/pressreleases/press-releasedetail/detail/a318-takes-off-on-maiden-flight/

Aircraft Model: AIRBUS A319

Aircraft Version: A319

Seats: Typical seating capacity. Source: Airbus Family booklet (2016)

Fuel Capacity: Source: Airbus Family booklet (2016)

Maximum Range: Source: Airbus Family booklet (2016)

First Flight: Source: http://www.dailypost.co.uk/business/business-news/airbus-a319-celebrates-

20th-anniversary-9930148

Aircraft Model: AIRBUS A320

Aircraft Version: A320

Seats: Typical seating capacity. Source: Airbus Family booklet (2016)

Fuel Capacity: Source: Airbus Family booklet (2016)

Maximum Range: Source: Airbus Family booklet (2016)

First Flight: Source: http://www.airbus.com/presscentre/pressreleases/press-releasedetail/detail/a320-roll-out-and-first-flight/ 
Aircraft Model: AIRBUS A321

Aircraft Version: A321

Seats: Typical seating capacity.

Source: Airbus Family booklet (2016)

Fuel Capacity: Source: Airbus Family booklet (2016)

Maximum Range: Source: Airbus Family booklet (2016)

First Flight: Source: http://www.airliners.net/aircraft-data/airbus-a321/24

Aircraft Model: AIRBUS A330

Aircraft Version: 200

Seats: Typical seating capacity. Source: Airbus Family booklet (2016)

Fuel Capacity: Source: Airbus Family booklet (2016)

Maximum Range: Source: Airbus Family booklet (2016)

First Flight: Source: http://www.airliners.net/aircraft-data/airbus-a330-200/26

Aircraft Model: AIRBUS A330

Aircraft Version: 300

Seats: Typical seating capacity. Source: Airbus Family booklet (2016)

Fuel Capacity: Source: Airbus Family booklet (2016)

Maximum Range: Source: Airbus Family booklet (2016)

First Flight: Source: http://www.airbus.com/company/history/the-interactive-timeline/

Aircraft Model: AIRBUS 340

Aircraft Version: 200

Seats: Average between single-class and three-class.

Source: https://www.airlines-inform.com/commercial-aircraft/Airbus-A340-200.html

Fuel Capacity: Standard fuel capacity.

Source: $\mathrm{http}: / / w w w . a i r b u s . c o m / a i r c r a f t f a m i l i e s / p r e v i o u s-g e n e r a t i o n-a i r c r a f t / a 340 f a m i l y / a 340-200 /$

Maximum Range: http:/www.airbus.com/aircraftfamilies/previous-generation-aircraft/a340family/

First Flight: Source: http://www.airbus.com/company/history/the-interactive-timeline/

Aircraft Model: AIRBUS 340

Aircraft Version: 300

Seats: Typical number of seats.

Source: $\mathrm{http}: / / w w w . a i r b u s . c o m / a i r c r a f t f a m i l i e s / p r e v i o u s-g e n e r a t i o n-a i r c r a f t / a 340 f a m i l y / a 340-300 /$

Fuel Capacity: Alternative source: http://www.airbus.com/aircraftfamilies/previous-generationaircraft/a340family/a340-300/

Maximum Range:

Alternative source: http://www.airbus.com/aircraftfamilies/previous-generationaircraft/a340family/a340-300/

First Flight: Source: http://www.airliners.net/aircraft-data/airbus-a340-200300/27

Aircraft Model: AIRBUS 340

Aircraft Version: 500

Seats: Typical number of seats.

Source: http://www.airbus.com/aircraftfamilies/previous-generation-aircraft/a340family/a340-500/

Fuel Capacity: Source: http://www.airbus.com/aircraftfamilies/previous-generationaircraft/a340family/a340-500/

Maximum Range: Source: http://www.airbus.com/aircraftfamilies/previous-generationaircraft/a340family/a340-500/

First Flight: Source: http://www.airliners.net/aircraft-data/airbus-a340-500600/28

Aircraft Model: AIRBUS 340

Aircraft Version: 600

Seats: Typical number of seats. 
Source: http://www.airbus.com/aircraftfamilies/previous-generation-aircraft/a340family/a340-600/

Fuel Capacity: Source: http://www.airbus.com/aircraftfamilies/previous-generationaircraft/a340family/a340-600/

Maximum Range: Source: http://www.airbus.com/aircraftfamilies/previous-generationaircraft/a340family/a340-600/

First Flight: Source: http://www.airliners.net/aircraft-data/airbus-a340-500600/28

Aircraft Model: AIRBUS A350

Aircraft Version: 900

Seats: Typical number of seats.

Source: http://www.airbus.com/aircraftfamilies/passengeraircraft/a350xwbfamily/a350-900/

Fuel Capacity: Source:

http://www.airbus.com/aircraftfamilies/passengeraircraft/a350xwbfamily/a350-900/

Maximum Range: Source:

http://www.airbus.com/aircraftfamilies/passengeraircraft/a350xwbfamily/a350-900/

First Flight: Source: https://en.wikipedia.org/wiki/Airbus_A350_XWB

Aircraft Model: AIRBUS 380

Aircraft Version: A380

Seats: Typical seating capacity. Source: Airbus Family booklet (2016) pp. 11

Fuel Capacity:

http://www.airbus.com/fileadmin/media_gallery/files/brochures_publications/aircraft_families/Airbus -Family-figures-booklet-March2016.pdf

Maximum Range:

http://www.airbus.com/fileadmin/media_gallery/files/brochures_publications/aircraft_families/Airbus -Family-figures-booklet-March2016.pdf

First Flight: Source: https://airwaysmag.com/airchive/flashback-friday-10th-anniversary-of-airbusa380s-maiden-flight/

\section{Aircraft Model: ANTONOV}

Aircraft Version: AN-72/74

Seats: Average of 72 and 74 seating capacity.

Source(s): (72) http://www.airliners.net/aircraft-data/antonov-an-7274/39; (74)

http://www.antonov.com/aircraft/passenger-aircraft/an-74

Fuel Capacity: Average of 72 and 74 fuel capacities.

Source: http://www.dutchops.com/AC_Data/Antonov/Antonov_74/Antonov_An72_74.htm

Maximum Range: Average of 72 and 74 given maximum fuel and reserves.

Source: $\mathrm{http}: / /$ www.airliners.net/aircraft-data/antonov-an-7274/39

First Flight: Refers to 72.Source: http://www.airliners.net/aircraft-data/antonov-an-7274/39

\section{Aircraft Model: ANTONOV}

Aircraft Version: AN-140

Seats: Source: http://www.airliners.net/aircraft-data/antonov-an-140/405

Fuel Capacity: The original data was 4400 , but that was measurement was in $\mathrm{kg}$. We converted this number to litres assuming a volume mass of $.782 \mathrm{~kg} / \mathrm{L}$ (number given in EASA, 2016).

Source: https://www.airlines-inform.com/commercial-aircraft/An-140.html

Maximum Range: Average of AI-30s and PW127s (both with 52 passengers).

Source: http://www.airliners.net/aircraft-data/antonov-an-140/405

First Flight: Source: http://www.airliners.net/aircraft-data/antonov-an-140/405

\section{Aircraft Model: ANTONOV}

Aircraft Version: AN148

Seats: Average of three variation types $(-100 \mathrm{~A},-100 \mathrm{~B}$, and $-100 \mathrm{E})$.

Source: https://www.airlines-inform.com/commercial-aircraft/An-148.html

Fuel Capacity: Doesn't specify aircraft variation, we took -100B. 
Source: https://www.aircraftcompare.com/helicopter-airplane/Antonov-An-148/388

Maximum Range: Average of three variation types (-100A, $-100 \mathrm{~B}$, and $-100 \mathrm{E})$ assuming maximum payload. Source: https://www.airlines-inform.com/commercial-aircraft/An-148.html

First Flight: Source: http://www.antonov.com/aircraft/passenger-aircraft/an-148

\section{Aircraft Model: ANTONOV \\ Aircraft Version: AN-158}

Seats: Average of two different class layouts on offer.

Source: http://www.antonov.com/aircraft/passenger-aircraft/an-158

Fuel Capacity: The original data was 11900 , but that was measurement was in $\mathrm{kg}$. We converted this number to litres assuming a volume mass of $.782 \mathrm{~kg} / \mathrm{L}$ (number given in EASA, 2016).

NB: Variations are -200 , whereas most sources reference -100 .

Source: http://www.antonov.com/media/archive/FAMILY\%20OVERVIEW.pdf

Maximum Range: Average of two different class layouts on offer.

Source: http://www.antonov.com/aircraft/passenger-aircraft/an-158

First Flight: Source: http://www.antonov.com/aircraft/passenger-aircraft/an-158

\section{Aircraft Model: ANTONOV \\ Aircraft Version: AN-24}

Seats: Source: http://www.airliners.net/aircraft-data/antonov-an-24263032-xian-y-7/37

Fuel Capacity: The original data was 5100, but that was measurement was in $\mathrm{kg}$. We converted this number to litres assuming a volume mass of .782 kg/L (number given in EASA, 2016).

Source: https://www.airlines-inform.com/commercial-aircraft/An-24.html

Maximum Range: Maximum range with maximum fuel. Other sources claim $550 \mathrm{~km}$ with maximum payload. Source: http://www.airliners.net/aircraft-data/antonov-an-24263032-xian-y-7/37

First Flight: Source: http://www.airliners.net/aircraft-data/antonov-an-24263032-xian-y-7/37

\section{Aircraft Model: ANTONOV}

Aircraft Version: AN-26

Seats: Source: http://www.antonov.com/aircraft/antonov-gliders-and-airplanes/an-26

Fuel Capacity: Source: http://www.aeromarine.com/An-26.pdf

Maximum Range: Source: https://www.airlines-inform.com/commercial-aircraft/An-26.html

First Flight: Source: https://www.airlines-inform.com/commercial-aircraft/An-26.html

\section{Aircraft Model: ANTONOV}

\section{Aircraft Version: AN-28}

Seats: Source: https://www.airlines-inform.com/commercial-aircraft/An-28.html

Fuel Capacity: The original data was 1530, but that was measurement was in $\mathrm{kg}$. We converted this number to litres assuming a volume mass of $.782 \mathrm{~kg} / \mathrm{L}$ (number given in EASA, 2016).

Source: https://www.airlines-inform.com/commercial-aircraft/An-28.html

Maximum Range: Source: https://www.airlines-inform.com/commercial-aircraft/An-28.html

First Flight: Source: https://www.airlines-inform.com/commercial-aircraft/An-28.html

\section{Aircraft Model: ANTONOV}

Aircraft Version: AN-3T

Seats: Source: https://www.airlines-inform.com/commercial-aircraft/An-2.html

Fuel Capacity: The original data was 1270, but that was measurement was in $\mathrm{kg}$. We converted this number to litres assuming a volume mass of .782 kg/L (number given in EASA, 2016).

Source: https://www.airlines-inform.com/commercial-aircraft/An-2.html

Maximum Range: Source: https://www.airlines-inform.com/commercial-aircraft/An-2.html

First Flight: Source: https://www.airlines-inform.com/commercial-aircraft/An-2.html

\section{Aircraft Model: ANTONOV}

Aircraft Version: AN38

Seats: Source: https://www.airlines-inform.com/commercial-aircraft/An-38.html 
Fuel Capacity: Source: https://www.airlines-inform.com/commercial-aircraft/An-38.html Maximum Range: NB: alternative sources (i.e., http://www.airliners.net/aircraft-data/antonov-an38/404) suggest a higher range. Source: https://www.airlines-inform.com/commercial-aircraft/An38.html

First Flight: Source: https://www.airlines-inform.com/commercial-aircraft/An-38.html

\section{Aircraft Model: ATR42}

Aircraft Version: 300

Seats: Source: http://www.atraircraft.com/products_app/media/pdf/FAMILY_septembre2014.pdf Fuel Capacity: The original data was 4500 , but that was measurement was in $\mathrm{kg}$. We converted this number to litres assuming a volume mass of $.782 \mathrm{~kg} / \mathrm{L}$ (number given in EASA, 2016). Source: http://www.atraircraft.com/products_app/media/pdf/FAMILY_septembre2014.pdf Maximum Range:

Source: http://www.atraircraft.com/products_app/media/pdf/FAMILY_septembre2014.pdf First Flight: Source: http://www.airliners.net/aircraft-data/atr-atr-42/41

\section{Aircraft Model: ATR42}

Aircraft Version: 400

Seats: Source: http://www.atraircraft.com/products_app/media/pdf/FAMILY_septembre2014.pdf Fuel Capacity: The original data was 4500 , but that was measurement was in $\mathrm{kg}$. We converted this number to litres assuming a volume mass of $.782 \mathrm{~kg} / \mathrm{L}$ (number given in EASA, 2016).

Source: http://www.atraircraft.com/products_app/media/pdf/FAMILY_septembre2014.pdf Maximum Range:

Source: http://www.atraircraft.com/products_app/media/pdf/FAMILY_septembre2014.pdf First Flight: Source: https://www.flightglobal.com/news/articles/atr-42-400-first-flight-25364/

\section{Aircraft Model: ATR42}

Aircraft Version: 500

Seats: Source: http://www.atraircraft.com/products_app/media/pdf/FAMILY_septembre2014.pdf

Fuel Capacity: The original data was 4500, but that was measurement was in $\mathrm{kg}$. We converted this number to litres assuming a volume mass of .782 $\mathrm{kg} / \mathrm{L}$ (number given in EASA, 2016).

Source: http://www.atraircraft.com/products_app/media/pdf/FAMILY_septembre2014.pdf Maximum Range:

Source: http://www.atraircraft.com/products_app/media/pdf/FAMILY_septembre2014.pdf First Flight: Source: http://airlinergallery.nl/atr42.htm

Aircraft Model: ATR42

Aircraft Version: 600

Seats: Source: http://www.atraircraft.com/products_app/media/pdf/FAMILY_septembre2014.pdf Fuel Capacity: The original data was 4500, but that was measurement was in $\mathrm{kg}$. We converted this number to litres assuming a volume mass of $.782 \mathrm{~kg} / \mathrm{L}$ (number given in EASA, 2016). Source: http://www.atraircraft.com/products_app/media/pdf/FAMILY_septembre2014.pdf Maximum Range:

Source: http://www.atraircraft.com/products_app/media/pdf/FAMILY_septembre2014.pdf First Flight: Source: http://www.ainonline.com/aviation-news/2010-03-04/atr-42-600-completesfirst-flight

\section{Aircraft Model: ATR72}

Aircraft Version: 200

Seats: Source: http://www.atraircraft.com/products_app/media/pdf/FAMILY_septembre2014.pdf Fuel Capacity: The original data was 5000, but that was measurement was in $\mathrm{kg}$. We converted this number to litres assuming a volume mass of $.782 \mathrm{~kg} / \mathrm{L}$ (number given in EASA, 2016).

Source: http://www.atraircraft.com/products_app/media/pdf/FAMILY_septembre2014.pdf Maximum Range:

Source: http://www.atraircraft.com/products_app/media/pdf/FAMILY_septembre2014.pdf 
First Flight: Source: http://www.scmp.com/news/china/article/1702538/taiwan-crash-puts-atr-72600-airliner-back-spotlight

\section{Aircraft Model: ATR72}

Aircraft Version: 210

Seats: Source: http://www.atraircraft.com/products_app/media/pdf/FAMILY_septembre2014.pdf Fuel Capacity: The original data was 5000, but that was measurement was in $\mathrm{kg}$. We converted this number to litres assuming a volume mass of .782 kg/L (number given in EASA, 2016).

Source: http://www.atraircraft.com/products_app/media/pdf/FAMILY_septembre2014.pdf Maximum Range:

Source: http://www.atraircraft.com/products_app/media/pdf/FAMILY_septembre2014.pdf First Flight: Source: https://www.airlines-inform.com/commercial-aircraft/ATR-72.html

Aircraft Model: ATR72

Aircraft Version: 500

Seats: Source: http://www.atraircraft.com/products_app/media/pdf/FAMILY_septembre2014.pdf

Fuel Capacity: The original data was 5000, but that was measurement was in $\mathrm{kg}$. We converted this number to litres assuming a volume mass of .782 $\mathrm{kg} / \mathrm{L}$ (number given in EASA, 2016).

Source: http://www.atraircraft.com/products_app/media/pdf/FAMILY_septembre2014.pdf

Maximum Range:

Source: http://www.atraircraft.com/products_app/media/pdf/FAMILY_septembre2014.pdf

First Flight: Source: https://www.airlines-inform.com/commercial-aircraft/ATR-72.html

Aircraft Model: ATR72

Aircraft Version: 600

Seats: Source: http://www.atraircraft.com/products_app/media/pdf/FAMILY_septembre2014.pdf

Fuel Capacity: The original data was 5000, but that was measurement was in $\mathrm{kg}$. We converted this number to litres assuming a volume mass of .782 $\mathrm{kg} / \mathrm{L}$ (number given in EASA, 2016).

Source: http://www.atraircraft.com/products_app/media/pdf/FAMILY_septembre2014.pdf

Maximum Range:

Source: http://www.atraircraft.com/products_app/media/pdf/FAMILY_septembre2014.pdf

First Flight: Source: https://www.airlines-inform.com/commercial-aircraft/ATR-72.html

Aircraft Model: BAE (HS) 748

Aircraft Version: HS 148 Series 2A

Seats: Source: http://www.airliners.net/aircraft-data/hawker-siddeley-hs-748/57

Fuel Capacity: Source:

https://www.easa.europa.eu/system/files/dfu/TCDS_EASA.A.397_HS748_Iss_02_20150115.pdf

Maximum Range: Assuming maximum payload and reserves.

Source: http://www.airliners.net/aircraft-data/hawker-siddeley-hs-748/57

First Flight: Source: http://www.airliners.net/aircraft-data/hawker-siddeley-hs-748/57

Aircraft Model: BAE ATP

Aircraft Version: ATP

Seats: Source: http://www.flugzeuginfo.net/acdata_php/acdata_atp_en.php

Fuel Capacity: Source: https://www.airlines-inform.com/commercial-aircraft/BAe-ATP.html Maximum Range: Source: https://www.airlines-inform.com/commercial-aircraft/BAe-ATP.html First Flight: Source: http://www.flugzeuginfo.net/acdata_php/acdata_atp_en.php

\section{Aircraft Model: BAE SYSTEMS AVRO RJ}

Aircraft Version: RJ85 / (146RJ 200 - original version)

Seats: Source: http://www.airliners.net/aircraft-data/british-aerospace-avro-rj7085100/47

Fuel Capacity: Source: https://www.regional-services.com/wp-content/uploads/2016/01/Remote-

Runway-Operations.pdf 
Maximum Range: Source:

http://www.qualitywingssim.com/files/ultimate 146 collection/docs/QualityWings_Ultimate_146_C ollection_Users_Manual_SP4.pdf

First Flight: Source: http://www.flugzeuginfo.net/acdata_php/acdata_bae1462_en.php

Aircraft Model: BAE SYSTEMS AVRO RJ

Aircraft Version: RJ100 (146 RJ300 - original version)

Seats: Source: http://www.airliners.net/aircraft-data/british-aerospace-avro-rj7085100/47

Fuel Capacity: Source:

https://www.regional-services.com/wp-content/uploads/2016/01/Remote-Runway-Operations.pdf

Maximum Range: Source:

http://www.qualitywingssim.com/files/ultimate_146_collection/docs/QualityWings_Ultimate_146_C ollection_Users_Manual_SP4.pdf

First Flight: Source: http://www.flugzeuginfo.net/acdata_php/acdata_bae1463_en.php

Aircraft Model: BAE

Aircraft Version: 146-100

Seats: Source: https://www.airlines-inform.com/commercial-aircraft/BAe-146.html

Fuel Capacity: Source: https://www.airlines-inform.com/commercial-aircraft/BAe-146.html

Maximum Range: Source: https://www.airlines-inform.com/commercial-aircraft/BAe-146.html

First Flight: Source:

http://www.qualitywingssim.com/files/ultimate_146_collection/docs/QualityWings_Ultimate_146_C ollection_Users_Manual_SP4.pdf

Aircraft Model: BAE

Aircraft Version: JETSTREAM 31

Seats: Source: http://www.airliners.net/aircraft-data/british-aerospace-jetstream-31 super-31/55

Fuel Capacity: Source: https://www.airlines-inform.com/commercial-aircraft/Jetstream-31.html

Maximum Range: Assuming maximum passengers and reserves.

Source: http://www.airliners.net/aircraft-data/british-aerospace-jetstream-31super-31/55

First Flight: Source: http://www.airliners.net/aircraft-data/british-aerospace-jetstream-31 super-31/55

Aircraft Model: BAE

Aircraft Version: JETSTREAM-41

Seats: Source: http://www.airliners.net/aircraft-data/british-aerospace-jetstream-41/56

Fuel Capacity: Source: https://www.airlines-inform.com/commercial-aircraft/Jetstream-41.html

Maximum Range: Assuming maximum passengers and reserves.

Source: http://www.airliners.net/aircraft-data/british-aerospace-jetstream-41/56

First Flight: Source: http://www.airliners.net/aircraft-data/british-aerospace-jetstream-41/56

Aircraft Model: BEECHCRAFT

Aircraft Version: 1900C

Seats: Source: http://www.airliners.net/aircraft-data/raytheon-beechcraft-1900/329

Fuel Capacity: Source: https://www.airlines-inform.com/commercial-aircraft/Beech-1900.html, with

Maximum Range: Maximum range with full payload, Source: https://www.airlines-

inform.com/commercial-aircraft/Beech-1900.html

First Flight: Source: http://www.airliners.net/aircraft-data/raytheon-beechcraft-1900/329

Aircraft Model: BEECHCRAFT

Aircraft Version: 1900D

Seats: Source: https://www.airlines-inform.com/commercial-aircraft/Beech-1900.html

Fuel Capacity: Source: https://www.airlines-inform.com/commercial-aircraft/Beech-1900.html

Maximum Range: Maximum range, Source: https://www.airlines-inform.com/commercialaircraft/Beech-1900.html

First Flight: Source: https://www.airlines-inform.com/commercial-aircraft/Beech-1900.html 
Aircraft Model: BEECHCRAFT

Aircraft Version: B99

Seats: Source: http://www.airliners.net/aircraft-data/beech-99-airliner/66

Fuel Capacity: The original data was 1119, but that was measurement was in $\mathrm{kg}$. We converted this number to litres assuming a volume mass of .782 kg/L (number given in EASA, 2016).

Source: http://all-aero.com/index.php/59-planes-b-c/1402-beech-99-commuter

Maximum Range: Assuming maximum cruising speed.

Source: http://www.airliners.net/aircraft-data/beech-99-airliner/66

First Flight: Source: http://www.airliners.net/aircraft-data/beech-99-airliner/66

Aircraft Model: BOEING

Aircraft Version: 707-120

Seats: Source: http://www.boeing.com/history/products/707.page

Fuel Capacity: Fuel capacity for $-120 \mathrm{~B}$ not -120 .

Maximum Range: Source: http://www.boeing.com/history/products/707.page

First Flight: Source: http://www.boeing.com/history/products/707.page

Aircraft Model: BOEING

Aircraft Version: 717-200

Seats: Average between maximum one-class seating and two-class seating.

Source: http://www.qantas.com/travel/airlines/aircraft-seat-map-boeing-712/global/en

Fuel Capacity: Source: http://www.qantas.com/travel/airlines/aircraft-seat-map-boeing-712/global/en

Maximum Range: Assuming maximum payload.

Source: http://www.qantas.com/travel/airlines/aircraft-seat-map-boeing-712/global/en

First Flight: Source: http://www.boeing.com/history/products/717-md-95.page

Aircraft Model: BOEING

Aircraft Version: 727-100

Seats: Typical mixed-class. Source:

http://www.boeing.com/resources/boeingdotcom/commercial/airports/acaps/727.pdf

Fuel Capacity: Source:

http://www.boeing.com/resources/boeingdotcom/commercial/airports/acaps/727.pdf

Maximum Range: Source: http://www.boeing.com/history/products/727.page

First Flight: Source: http://www.boeing.com/history/products/707.page

Aircraft Model: BOEING

Aircraft Version: 727-200 advanced

Seats: Average between certified and mixed-class.

Source: http://www.boeing.com/resources/boeingdotcom/commercial/airports/acaps/727.pdf

Fuel Capacity:

Source: http://www.boeing.com/resources/boeingdotcom/commercial/airports/acaps/727.pdf

Maximum Range: Source: http://www.flugzeuginfo.net/acdata_php/acdata_727_en.php

First Flight: Source: http://www.flugzeuginfo.net/acdata_php/acdata_727_en.php

Aircraft Model: BOEING

Aircraft Version: 737-100

Seats: Average between FAA exit limit and two-class.

Source: http://www.boeing.com/resources/boeingdotcom/commercial/airports/acaps/737.pdf

Fuel Capacity: Average of three listed usable fuel capacities.

http://www.boeing.com/resources/boeingdotcom/commercial/airports/acaps/737.pdf

Maximum Range: Source: http://www.flugzeuginfo.net/acdata_php/acdata_7371_en.php

First Flight: Source: http://www.boeing.com/history/products/737-classic.page 
Aircraft Model: BOEING

Aircraft Version: 737-200

Seats: Average between FAA exit limit and two-class.

Source: http://www.boeing.com/resources/boeingdotcom/commercial/airports/acaps/737.pdf

Fuel Capacity: Average of 5 listed fuel capacities.

Source: http://www.boeing.com/resources/boeingdotcom/commercial/airports/acaps/737.pdf

Maximum Range: Source: http://www.flugzeuginfo.net/acdata_php/acdata_7372_en.php

First Flight: Source: http://www.flugzeuginfo.net/acdata_php/acdata_7372_en.php

Aircraft Model: BEOING

Aircraft Version: 737-300

Seats: Source: http://www.boeing.com/resources/boeingdotcom/commercial/airports/acaps/737.pdf

Fuel Capacity: Assuming a CFM56-3B1 engine is used.

Source: http://www.boeing.com/resources/boeingdotcom/commercial/airports/acaps/737.pdf

Maximum Range: Assuming a CFM56-3B1 engine is used and maximum payload.

Source: https://www.airlines-inform.com/commercial-aircraft/Boeing-737-300.html

First Flight: Source: https://www.airlines-inform.com/commercial-aircraft/Boeing-737-300.html

\section{Aircraft Model: BOEING}

Aircraft Version: 737-400

Seats: Average between FAA exit limit and two-class.

http://www.boeing.com/resources/boeingdotcom/commercial/airports/acaps/737.pdf

Fuel Capacity: Assuming a CFM56-3B2 engine is used. Source:

http://www.boeing.com/resources/boeingdotcom/commercial/airports/acaps/737.pdf

Maximum Range: Assuming a CFM56-3B2 engine is used and maximum payload.

Source: https://www.airlines-inform.com/commercial-aircraft/Boeing-737-400.html

First Flight: Source: https://www.airlines-inform.com/commercial-aircraft/Boeing-737-400.html

\section{Aircraft Model: BOEING}

Aircraft Version: 737-500

Seats: Average between FAA exit limit and two-class.

http://www.boeing.com/resources/boeingdotcom/commercial/airports/acaps/737.pdf

Fuel Capacity: Assuming a CFM56-3B2 engine is used.

Source: http://www.boeing.com/resources/boeingdotcom/commercial/airports/acaps/737.pdf

Maximum Range: Assuming a CFM56-B31 engine is used and maximum payload.

Source: https://www.airlines-inform.com/commercial-aircraft/Boeing-737-500.html

First Flight: Source: https://www.airlines-inform.com/commercial-aircraft/Boeing-737-500.html

\section{Aircraft Model: BOEING}

Aircraft Version: 737-600

Seats: Average between all-economy and two-class.

http://www.boeing.com/resources/boeingdotcom/commercial/airports/acaps/737.pdf

Fuel Capacity: Source: http://www.boeing.com/assets/pdf/commercial/airports/acaps/737.pdf

Maximum Range: Source: http://boeing.mediaroom.com/1998-06-29-China-to-Purchase-10-BoeingNext-Generation-737-Jetliners

First Flight: Source: https://www.airlines-inform.com/commercial-aircraft/Boeing-737-600.html

Aircraft Model: BOEING

Aircraft Version: 737-700

Seats: Average between all-economy and two-class.

Source: http://www.boeing.com/resources/boeingdotcom/commercial/airports/acaps/737.pdf

Fuel Capacity: Source: http://www.boeing.com/assets/pdf/commercial/airports/acaps/737.pdf

Maximum Range: Source: http://boeing.mediaroom.com/1998-06-29-China-to-Purchase-10-BoeingNext-Generation-737-Jetliners

First Flight: Source: https://www.airlines-inform.com/commercial-aircraft/Boeing-737-700.html 
Aircraft Model: BOEING

Aircraft Version: 737-800

Seats: Source: http://www.boeing.com/resources/boeingdotcom/commercial/airports/acaps/737.pdf

Fuel Capacity: Source: http://www.boeing.com/assets/pdf/commercial/airports/acaps/737.pdf

Maximum Range: Source: http://boeing.mediaroom.com/1998-06-29-China-to-Purchase-10-BoeingNext-Generation-737-Jetliners

First Flight: Source: https://www.airlines-inform.com/commercial-aircraft/Boeing-737-800.html

Aircraft Model: BOEING

Aircraft Version: 737-900

Seats: Average between all-economy and two-class.

Source: http://www.boeing.com/resources/boeingdotcom/commercial/airports/acaps/737.pdf

Fuel Capacity: Source: http://www.boeing.com/assets/pdf/commercial/airports/acaps/737.pdf

Maximum Range: Source: http://boeing.mediaroom.com/1998-06-29-China-to-Purchase-10-BoeingNext-Generation-737-Jetliners

First Flight: Source: https://www.airlines-inform.com/commercial-aircraft/Boeing-737-900.html

Aircraft Model: BOEING

Aircraft Version: 737-900ER

Seats: Average between FAA exit limit and two-class.

Source: http://www.boeing.com/resources/boeingdotcom/commercial/airports/acaps/737.pdf

Fuel Capacity: Source: http://www.boeing.com/assets/pdf/commercial/airports/acaps/737.pdf

Maximum Range: Source: http://boeing.mediaroom.com/2006-05-31-Boeing-Begins-Assemblingthe-First-737-900ER

First Flight: Source: https://en.wikipedia.org/wiki/Boeing_737

Aircraft Model: BOEING

Aircraft Version: 747-100

Seats: Average between all-economy and three-class.

Source: http://www.flugzeuginfo.net/acdata_php/acdata_7471_en.php

Fuel Capacity:

Source: http://www.boeing.com/resources/boeingdotcom/commercial/airports/acaps/747_123sp.pdf

Maximum Range: Source:

http://www.boeing.com/resources/boeingdotcom/company/about_bca/startup/pdf/historical/747-100_200_-300_SP_passenger.pdf

First Flight: Source: https://www.airlines-inform.com/commercial-aircraft/Boeing-747-100.html

Aircraft Model: BOEING

Aircraft Version: 747-200B

Seats: Average between all-economy and three-class.

Source: http://www.flugzeuginfo.net/acdata_php/acdata_7472_en.php

Fuel Capacity: Source: https://www.airlines-inform.com/commercial-aircraft/Boeing-747-200.html

Maximum Range: Assuming maximum payload. (Range may differ with engine type).

Source: https://www.airlines-inform.com/commercial-aircraft/Boeing-747-200.html

First Flight: Source: https://www.airlines-inform.com/commercial-aircraft/Boeing-747-200.html

Aircraft Model: BOEING

Aircraft Version: $747-300$

Seats: Average between one-class and three-class.

Source: https://www.airlines-inform.com/commercial-aircraft/Boeing-747-300.html

Fuel Capacity: Source: https://www.airlines-inform.com/commercial-aircraft/Boeing-747-300.html Maximum Range:

Source: https://www.airlines-inform.com/commercial-aircraft/Boeing-747-300.html 
First Flight: Source: https://www.airlines-inform.com/commercial-aircraft/Boeing-747-300.html

Aircraft Model: BOEING

Aircraft Version: 747-400

Seats: Average between one-class and three-class.

Source: https://www.airlines-inform.com/commercial-aircraft/Boeing-747-400.html

Fuel Capacity: (Fuel capacity may differ with engine type)

Source: https://www.airlines-inform.com/commercial-aircraft/Boeing-747-400.html

Maximum Range: Assuming maximum payload. (Range may differ with engine type)

Source: https://www.airlines-inform.com/commercial-aircraft/Boeing-747-400.html

First Flight: Source: https://www.airlines-inform.com/commercial-aircraft/Boeing-747-400.html

Aircraft Model: BOEING

Aircraft Version: 747-8I

Seats: Source: Typical seating capacity.

Fuel Capacity: Source: https://www.airlines-inform.com/commercial-aircraft/Boeing-747-8.html

Maximum Range: Source: https://www.airlines-inform.com/commercial-aircraft/Boeing-747-8.html

First Flight: Source: http://www.flugzeuginfo.net/acdata_php/acdata_boeing_7478_dt.php

\section{Aircraft Model: BOEING}

Aircraft Version: 747-SP

Seats: Average: class-type not specified.

Source: http://www.flugzeuginfo.net/acdata_php/acdata_boeing_747sp_dt.php

Fuel Capacity: Average between two engine types: RB211-524C2 and CF6-45A2/B2.

Source: http://www.boeing.com/resources/boeingdotcom/commercial/airports/acaps/747_123sp.pdf

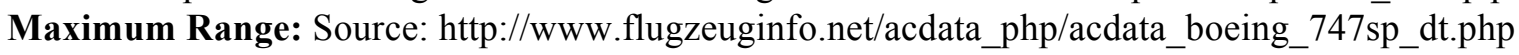

First Flight: Source: http://www.flugzeuginfo.net/acdata_php/acdata_boeing_747sp_dt.php

\section{Aircraft Model: BOEING}

Aircraft Version: 757-200

Seats: Average between four-door configuration and two-class.

Source: http://www.flugzeuginfo.net/acdata_php/acdata_7572_en.php

Fuel Capacity:

Source: http://www.boeing.com/resources/boeingdotcom/commercial/airports/acaps/757_23.pdf

Maximum Range: Source: https://www.airlines-inform.com/commercial-aircraft/Boeing-757-

200.html

First Flight: Source: https://www.airlines-inform.com/commercial-aircraft/Boeing-757-200.html

\section{Aircraft Model: BOEING}

Aircraft Version: 757-300

Seats: Average between all-economy and dual-class.

Source: http://www.boeing.com/resources/boeingdotcom/commercial/airports/acaps/757_23.pdf

Fuel Capacity:

http://www.boeing.com/resources/boeingdotcom/company/about_bca/startup/pdf/historical/757_passe nger.pdf

Maximum Range: Source: https://www.airlines-inform.com/commercial-aircraft/Boeing-757300.html

First Flight: Source: https://www.airlines-inform.com/commercial-aircraft/Boeing-757-300.html

Aircraft Model: BOEING

Aircraft Version: $767-200$

Seats: Average between FAA exit limit and (with second over the wing exit door) mixed-class.

Source: http://www.boeing.com/resources/boeingdotcom/commercial/airports/acaps/767.pdf

Fuel Capacity: Fuel capacity may differ with engine type)

Source: http://www.boeing.com/resources/boeingdotcom/commercial/airports/acaps/767.pdf 
Maximum Range: Source: http://www.flugzeuginfo.net/acdata_php/acdata_7672_en.php First Flight: http://www.boeing.com/history/products/767.page

\section{Aircraft Model: BOEING}

Aircraft Version: 767-200ER

Seats: Average between FAA exit limit and (with second over the wing exit door) mixed-class. Source: http://www.boeing.com/resources/boeingdotcom/commercial/airports/acaps/767.pdf Fuel Capacity: (Fuel capacity may differ with engine type) Source: http://www.boeing.com/resources/boeingdotcom/commercial/airports/acaps/767.pdf Maximum Range: Source: https://www.airlines-inform.com/commercial-aircraft/Boeing-767200.html

First Flight: Source: http://www.airliners.net/aircraft-data/boeing-767-200/103

\section{Aircraft Model: BOEING}

Aircraft Version: 767-300

Seats: Average between mid-cabin door and two-class.

Source: http://www.boeing.com/resources/boeingdotcom/commercial/airports/acaps/767.pdf

Fuel Capacity: http://www.boeing.com/assets/pdf/commercial/airports/acaps/767.pdf

Maximum Range: Source: https://www.airlines-inform.com/commercial-aircraft/Boeing-767300.html

First Flight: Source: http://www.airliners.net/aircraft-data/boeing-767-300/104

Aircraft Model: BOEING

Aircraft Version: 767-300ER

Seats: Average between mid-cabin door and two-class.

Source: http://www.boeing.com/resources/boeingdotcom/commercial/airports/acaps/767.pdf

Fuel Capacity: http://www.boeing.com/assets/pdf/commercial/airports/acaps/767.pdf

Maximum Range: Source: https://www.airlines-inform.com/commercial-aircraft/Boeing-767300.html

First Flight: Source: http://www.airliners.net/aircraft-data/boeing-767-300/104

\section{Aircraft Model: BOEING \\ Aircraft Version: 767-400ER}

Seats: Average between all-economy and three-class.

Source: http://www.boeing.com/resources/boeingdotcom/commercial/airports/acaps/767.pdf

Fuel Capacity: http://www.boeing.com/assets/pdf/commercial/airports/acaps/767.pdf

Maximum Range: Source: https://www.airlines-inform.com/commercial-aircraft/Boeing-767400.html

First Flight: Source: http://www.boeing.com/history/products/767.page

\section{Aircraft Model: BOEING}

Aircraft Version: $777-200$

Seats: Average between one-class and three-class.

Source: http://www.flugzeuginfo.net/acdata_php/acdata_7772_dt.php

Fuel Capacity:

Maximum Range: Source: http://www.aerospace-technology.com/projects/boeing777/

First Flight: Source: http://www.flugzeuginfo.net/acdata_php/acdata_7772_dt.php

Aircraft Model: BOEING

Aircraft Version: 777-200ER

Seats: 200ER has the same number of passengers as Version 200.

Source: http://www.aerospace-technology.com/projects/boeing777/

Fuel Capacity: Source: https://www.airlines-inform.com/commercial-aircraft/Boeing-777-300.html Maximum Range: Source: http://www.flugzeuginfo.net/acdata_php/acdata_7773_dt.php

First Flight: Source: http://www.skytamer.com/Boeing_777-200.html 
Aircraft Model: BOEING

Aircraft Version: 777-300

Seats: Average between one-class and three-class.

Source: https://www.airlines-inform.com/commercial-aircraft/Boeing-777-300.html

Fuel Capacity: Source: https://www.airlines-inform.com/commercial-aircraft/Boeing-777-300.html

Maximum Range: Source: http://www.flugzeuginfo.net/acdata_php/acdata_7773_dt.php

First Flight: Source: http://www.skytamer.com/Boeing_777-200.html

Aircraft Model: BOEING

Aircraft Version: 777-300ER

Seats: Average between one-class and three-class.

Source: https://www.airlines-inform.com/commercial-aircraft/Boeing-777-300.html

Fuel Capacity: Source: https://www.airlines-inform.com/commercial-aircraft/Boeing-777-300.html

Maximum Range: (Range may vary with different engine type)

Source: https://www.airlines-inform.com/commercial-aircraft/Boeing-777-300.html

First Flight: Source: http://www.aerospace-technology.com/projects/boeing777/

Aircraft Model: BOEING

Aircraft Version: 777-200LR

Seats: Average between one-class and three-class.

Source: https://www.airlines-inform.com/commercial-aircraft/Boeing-777-200.html

Fuel Capacity: Source: http://www.topspeed.com/aviation/aviation-reviews/boeing/2006-boeing777-200lr-ar87989.html

Maximum Range: Source: http://www.topspeed.com/aviation/aviation-reviews/boeing/2006-boeing777-2001r-ar87989.html

First Flight: Source: http://www.aerospace-technology.com/projects/boeing777/

Aircraft Model: BOEING

Aircraft Version: 787-8 Dreamliner

Seats: Average between one-class and three-class.

Source: http://www.aerospace-technology.com/projects/dreamliner/

Fuel Capacity: Source: https://www.airlines-inform.com/commercial-aircraft/Boeing-787.html

Maximum Range: http://www.boeing.com/commercial/787/\#/by-design

First Flight: Source: https://www.airlines-inform.com/commercial-aircraft/Boeing-787.html

Aircraft Model: BOEING

Aircraft Version: 787-9 Dreamliner

Seats: Typical seating capacity.

Source: http://www.flugzeuginfo.net/acdata_php/acdata_boeing_7879_dt.php

Fuel Capacity: Source: https://www.airlines-inform.com/commercial-aircraft/Boeing-787-9.html

Maximum Range: http://www.boeing.com/commercial/787/\#/by-design

First Flight: Source: http://www.flugzeuginfo.net/acdata_php/acdata_boeing_7879_dt.php

Aircraft Model: BOEING

Aircraft Version: MD-11

Seats: Average between single- and three-class seating capacities.

Source: http://www.airliners.net/aircraft-data/mcdonnell-douglas-md-11/112

Fuel Capacity: Source: https://www.airlines-inform.com/commercial-aircraft/MD-11.html

Maximum Range: Source: https://www.airlines-inform.com/commercial-aircraft/MD-11.html

First Flight: Source: http://www.boeing.com/history/products/md-11-commercial-transport.page

Aircraft Model: BOEING

Aircraft Version: MD-81 
Seats: Typical (two-class) seating capacity.

Source: http://www.airliners.net/aircraft-data/mcdonnell-douglas-md-81828388/109

Fuel Capacity: Usable fuel capacity.

Source: http://www.boeing.com/assets/pdf/commercial/airports/acaps/md80.pdf

Maximum Range: Source: http://www.boeing.com/history/products/md-80-and-md-90-commercialtransport.page

First Flight: Source: http://www.boeing.com/history/products/md-80-and-md-90-commercialtransport.page

Aircraft Model: BOEING

Aircraft Version: MD-82

Seats:

Average between single-class and two-class seating capacity.

Source: https://www.airlines-inform.com/commercial-aircraft/MD-80.html

Fuel Capacity: Standard fuel capacity.

Source: https://www.airlines-inform.com/commercial-aircraft/MD-80.html

Maximum Range: Assuming maximum payload.

Source: https://www.airlines-inform.com/commercial-aircraft/MD-80.html

First Flight: Based on: http://www.airliners.net/aircraft-data/mcdonnell-douglas-md-81828388/109.

Source: https://www.airlines-inform.com/commercial-aircraft/MD-80.html

Aircraft Model: BOEING

Aircraft Version: MD-83

Seats: Average between single-class and two-class seating capacity.

Source: https://www.airlines-inform.com/commercial-aircraft/MD-80.html

Fuel Capacity: Standard fuel capacity.

Source: https://www.airlines-inform.com/commercial-aircraft/MD-80.html

Maximum Range: Assuming maximum payload.

Source: https://www.airlines-inform.com/commercial-aircraft/MD-80.html

First Flight:

Aircraft Model: BOEING

Aircraft Version: MD-87

Seats: Average between single-class and two-class seating capacity.

Source: https://www.airlines-inform.com/commercial-aircraft/MD-80.html

Fuel Capacity: Standard fuel capacity.

Source: https://www.airlines-inform.com/commercial-aircraft/MD-80.html

Maximum Range: Assuming maximum payload.

Source: https://www.airlines-inform.com/commercial-aircraft/MD-80.html

First Flight: Source: http://www.airliners.net/aircraft-data/mcdonnell-douglas-md-87/278

Aircraft Model: BOEING

Aircraft Version: MD- 88

Seats: Average between single-class and two-class seating capacity.

Source: https://www.airlines-inform.com/commercial-aircraft/MD-80.html

Fuel Capacity: Standard fuel capacity.

Source: https://www.airlines-inform.com/commercial-aircraft/MD-80.html

Maximum Range: Assuming maximum payload.

Source: https://www.airlines-inform.com/commercial-aircraft/MD-80.html

First Flight: Source: http://www.airliners.net/aircraft-data/mcdonnell-douglas-md-81828388/109

Aircraft Model: BOEING

Aircraft Version: MD-90-30

Seats: Average between single-class and two-class seating capacity.

Source: https://www.airlines-inform.com/commercial-aircraft/MD-90.html 
Fuel Capacity: Standard fuel capacity.

Source: https://www.airlines-inform.com/commercial-aircraft/MD-90.html

Maximum Range: Assuming maximum payload.

Source: https://www.airlines-inform.com/commercial-aircraft/MD-90.html

First Flight: Source: http://www.boeing.com/history/products/md-80-and-md-90-commercialtransport.page

Aircraft Model: BOEING

Aircraft Version: MD-90-30ER

Seats: Average between single-class and two-class seating capacity. (Assuming same capacity based on: http://www.boeing.com/assets/pdf/commercial/airports/acaps/md90.pdf)

Source: https://www.airlines-inform.com/commercial-aircraft/MD-90.html

Fuel Capacity: Usable fuel capacity.

Source: http://www.boeing.com/assets/pdf/commercial/airports/acaps/md90.pdf

Maximum Range: Source: http://www.boeing.com/history/products/md-80-and-md-90-commercialtransport.page

First Flight:

Aircraft Model: BOMBARDIER

Aircraft Version: CRJ1000ER

Seats: Typical seating capacity.

Source: http://www.flugzeuginfo.net/acdata_php/acdata_bombardier_crj1000_en.php

Fuel Capacity: Source: http://www.flyradius.com/bombardier-crj1000/specifications

Maximum Range: Source:

http://commercialaircraft.bombardier.com/content/dam/Websites/bca/literature/crj/CRJ\%20Series_CR J\%201000_Factsheet_201607_EN.pdf

First Flight: Source: http://www.flugzeuginfo.net/acdata_php/acdata_bombardier_crj1000_en.php

Aircraft Model: BOMBARDIER

Aircraft Version: CRJ1000EL

Seats: Typical seating capacity.

Source: http://www.flugzeuginfo.net/acdata_php/acdata_bombardier_crj1000_en.php

Fuel Capacity: Source: http://www.flyradius.com/bombardier-crj1000/specifications

Maximum Range: Source:

http://commercialaircraft.bombardier.com/content/dam/Websites/bca/literature/crj/CRJ\%20Series_CR J\%201000_Factsheet_201607_EN.pdf

First Flight: Source: $\bar{h}$ ttp://www.flugzeuginfo.net/acdata_php/acdata_bombardier_crj1000_en.php

Aircraft Model: BOMBARDIER

Aircraft Version: CRJ100ER

Seats: Source: https://www.airlines-inform.com/commercial-aircraft/CRJ-family.html

Fuel Capacity:

Source: https://www.airlines-inform.com/commercial-aircraft/Bombardier-CRJ-200.html

Maximum Range:

Source: https://www.airlines-inform.com/commercial-aircraft/Bombardier-CRJ-200.html

First Flight: Source: https://www.airlines-inform.com/commercial-aircraft/CRJ-family.html

Aircraft Model: BOMBARDIER

Aircraft Version: CRJ100LR

Seats: Source: https://www.airlines-inform.com/commercial-aircraft/CRJ-family.html

Fuel Capacity:

Source: https://www.airlines-inform.com/commercial-aircraft/Bombardier-CRJ-200.html

Maximum Range:

Source: https://airwaysmag.com/airchive/flashback-friday-the-bombardier-crj-family/

First Flight: Source: https://www.airlines-inform.com/commercial-aircraft/CRJ-family.html 
Aircraft Model: BOMBARDIER

Aircraft Version: CRJ200ER

Seats: Source: https://www.airlines-inform.com/commercial-aircraft/CRJ-family.html

Fuel Capacity:

Source: https://www.airlines-inform.com/commercial-aircraft/Bombardier-CRJ-200.html

Maximum Range:

Source: https://www.airlines-inform.com/commercial-aircraft/Bombardier-CRJ-200.html

First Flight: Source: http://www.flugzeuginfo.net/acdata_php/acdata_crj200_en.php

Aircraft Model: BOMBARDIER

Aircraft Version: CRJ200LR

Seats: Source: https://www.airlines-inform.com/commercial-aircraft/CRJ-family.html

Fuel Capacity:

Source: https://www.airlines-inform.com/commercial-aircraft/Bombardier-CRJ-200.html

Maximum Range:

Source: https://www.airlines-inform.com/commercial-aircraft/Bombardier-CRJ-200.html

First Flight: Source: http://www.flugzeuginfo.net/acdata_php/acdata_crj200_en.php

Aircraft Model: BOMBARDIER

Aircraft Version: CRJ700

Seats: Average between maximum and dual-class seating capacity. Source:

http://commercialaircraft.bombardier.com/content/dam/Websites/bca/literature/crj/CRJ\%20Series_Br ochure_201607_EN.pdf

Fuel Capacity:

Source: https://www.airlines-inform.com/commercial-aircraft/Bombardier-CRJ-700.html

Maximum Range:

Source: https://www.airlines-inform.com/commercial-aircraft/Bombardier-CRJ-700.html

First Flight: Source: https://www.airlines-inform.com/commercial-aircraft/Bombardier-CRJ-

700.html

Aircraft Model: BOMBARDIER

Aircraft Version: CRJ700ER

Seats: Source: https://www.airlines-inform.com/commercial-aircraft/Bombardier-CRJ-700.html

Fuel Capacity:

Source: https://www.airlines-inform.com/commercial-aircraft/Bombardier-CRJ-700.html

Maximum Range:

Source: https://www.airlines-inform.com/commercial-aircraft/Bombardier-CRJ-700.html

First Flight: Source: https://www.airlines-inform.com/commercial-aircraft/Bombardier-CRJ-

700.html

Aircraft Model: BOMBARDIER

Aircraft Version: CRJ700LR

Seats: Source: https://www.airlines-inform.com/commercial-aircraft/Bombardier-CRJ-700.html

Fuel Capacity:

Source: https://www.airlines-inform.com/commercial-aircraft/Bombardier-CRJ-700.html

Maximum Range:

Source: https://www.airlines-inform.com/commercial-aircraft/Bombardier-CRJ-700.html

First Flight:

Source: https://www.airlines-inform.com/commercial-aircraft/Bombardier-CRJ-700.html

Aircraft Model: BOMBARDIER

Aircraft Version: CRJ900ER 
Seats: Average between maximum and triple-class seating capacity. Source:

http://commercialaircraft.bombardier.com/content/dam/Websites/bca/literature/crj/CRJ\%20Series_Br ochure_201607_EN.pdf

Fuel Capacity:

Source: https://www.airlines-inform.com/commercial-aircraft/Bombardier-CRJ-900.html

Maximum Range:

Source: https://www.airlines-inform.com/commercial-aircraft/Bombardier-CRJ-900.html

First Flight: Source: https://www.airlines-inform.com/commercial-aircraft/Bombardier-CRJ900.html

Aircraft Model: BOMBARDIER

Aircraft Version: CRJ900LR

Seats: Average between maximum and triple-class seating capacity. Source:

http://commercialaircraft.bombardier.com/content/dam/Websites/bca/literature/crj/CRJ\%20Series_Br ochure 201607_EN.pdf

Fuel Capacity:

Source: https://www.airlines-inform.com/commercial-aircraft/Bombardier-CRJ-900.html

Maximum Range:

Source: https://www.airlines-inform.com/commercial-aircraft/Bombardier-CRJ-900.html

First Flight: Source: https://www.airlines-inform.com/commercial-aircraft/Bombardier-CRJ-

900.html

Aircraft Model: BOMBARDIER

Aircraft Version: DASH 8 Q100

Seats: Source: https://www.airlines-inform.com/commercial-aircraft/Dash-8Q200.html

Fuel Capacity: Source: https://www.airlines-inform.com/commercial-aircraft/Dash-8Q200.html

Maximum Range: Source: https://www.airlines-inform.com/commercial-aircraft/Dash-8Q200.html

First Flight: Source: https://www.airlines-inform.com/commercial-aircraft/Dash8-family.html

Aircraft Model: BOMBARDIER

Aircraft Version: DASH 8 Q200

Seats: Source: https://www.airlines-inform.com/commercial-aircraft/Dash-8Q200.html

Fuel Capacity: Source: https://www.airlines-inform.com/commercial-aircraft/Dash-8Q200.html

Maximum Range: Source: https://www.airlines-inform.com/commercial-aircraft/Dash-8Q200.html

First Flight: Source: https://www.airlines-inform.com/commercial-aircraft/Dash8-family.html

Aircraft Model: BOMBARDIER

Aircraft Version: DASH 8 Q300

Seats: Average between economy-class and standard seating capacity.

Source: https://www.airlines-inform.com/commercial-aircraft/Dash-8Q300.html

Fuel Capacity: Source: https://www.airlines-inform.com/commercial-aircraft/Dash-8Q300.html

Maximum Range: Average between low, medium, and high.

Source: https://www.airlines-inform.com/commercial-aircraft/Dash-8Q300.html

First Flight: Source: https://www.airlines-inform.com/commercial-aircraft/Dash-8Q300.html

Aircraft Model: BOMBARDIER

Aircraft Version: DASH 8 Q400

Seats: Maximum seating capacity. Source:

http://commercialaircraft.bombardier.com/content/dam/Websites/bca/literature/q400/Q\%20Series_fac tsheets_201607_EN.pdf

Fuel Capacity: Source: https://www.airlines-inform.com/commercial-aircraft/Dash-8Q400.html

Maximum Range: Source: https://www.airlines-inform.com/commercial-aircraft/Dash-8Q400.html

First Flight: Source: https://www.airlines-inform.com/commercial-aircraft/Dash-8Q400.html

Aircraft Model: CONVAIR 
Aircraft Version: CV-580

Seats:

Fuel Capacity:

Maximum Range:

First Flight: Source: https://www.airlines-inform.com/commercial-aircraft/Convair-580.html

Aircraft Model: CONVAIR

Aircraft Version: CV-640

Seats: Source: http://www.flugzeuginfo.net/acdata_php/acdata_cv640_en.php

Fuel Capacity:

Maximum Range: Source: http://www.flugzeuginfo.net/acdata_php/acdata_cv640_en.php

First Flight: Source: http://www.flugzeuginfo.net/acdata_php/acdata_cv640_en.php

\section{Aircraft Model: DE HAVILLAND CANADA}

Aircraft Version: DHC7

Seats: Source: http://www.flugzeuginfo.net/acdata_php/acdata_dhc7_en.php

Fuel Capacity: The original data was 4502, but that was measurement was in $\mathrm{kg}$. We converted this number to litres assuming a volume mass of .782 $\mathrm{kg} / \mathrm{L}$ (number given in EASA, 2016).

Source: http://members.aon.at/ slenz/dash7.html

Maximum Range: Source: http://www.flugzeuginfo.net/acdata_php/acdata_dhc7_en.php

First Flight: Source: http://www.flugzeuginfo.net/acdata_php/acdata_dhc7_en.php

Aircraft Model: DE HAVILLAND CANADA TWIN OTTER

Aircraft Version: DHC-6-400 (Viking)

Seats: Source: http://www.aerospace-technology.com/projects/vikingdhc6400/

Fuel Capacity:

Maximum Range: Source: http://www.aerospace-technology.com/projects/vikingdhc6400/

First Flight: Source: http://www.aerospace-technology.com/projects/vikingdhc6400/

Aircraft Model: DORNIER

Aircraft Version: 228

Seats: Source: http://www.airforce-technology.com/projects/dornier-do-228-light-transport-aircraft/ Fuel Capacity: Maximum fuel capacity. Source:

https://www.easa.europa.eu/system/files/dfu/TCDS\%20\%20EASA\%20A\%20359\%20Dornier\%20228 \%20Issue\%205.pdf

Maximum Range: Source: http://www.airforce-technology.com/projects/dornier-do-228-lighttransport-aircraft/

First Flight: Source: http://www.airforce-technology.com/projects/dornier-do-228-light-transportaircraft/

Aircraft Model: DORNIER

Aircraft Version: 328

Seats: Source: https://www.airlines-inform.com/commercial-aircraft/Dornier-328.html

Fuel Capacity: Source: https://www.airlines-inform.com/commercial-aircraft/Dornier-328.html

Maximum Range: Source: https://www.airlines-inform.com/commercial-aircraft/Dornier-328.html

First Flight: Source: https://www.airlines-inform.com/commercial-aircraft/Dornier-328.html

Aircraft Model: DORNIER

Aircraft Version: 328JET

Seats: Source: https://www.airlines-inform.com/commercial-aircraft/Dornier-328Jet.html

Fuel Capacity: Source: https:/www.airlines-inform.com/commercial-aircraft/Dornier-328Jet.html

Maximum Range: Source: https://www.airlines-inform.com/commercial-aircraft/Dornier328Jet.html

First Flight: Source: http://www.flugzeuginfo.net/acdata_php/acdata_do328jet_en.php 
Aircraft Model: EMBRAER

Aircraft Version: EMB-110 BANDEIRANTE

Seats: Standard fuel capacity.

Source: https://www.airlines-inform.com/commercial-aircraft/Embraer-110-Bandeirante.html

Fuel Capacity: Source: http://www.flugzeuginfo.net/acdata_php/acdata_emb110_en.php

Maximum Range: Source: http://www.flugzeuginfo.net/acdata_php/acdata_emb110_en.php

First Flight: Source: http://www.flugzeuginfo.net/acdata_php/acdata_emb110_en.php

Aircraft Model: EMBRAER

Aircraft Version: EMB-120 BRASILIA

Seats: Source: http://www.flugzeuginfo.net/acdata_php/acdata_emb120_en.php

Fuel Capacity: The original data was 2600, but that was measurement was in $\mathrm{kg}$. We converted this number to litres assuming a volume mass of $.782 \mathrm{~kg} / \mathrm{L}$ (number given in EASA, 2016). Source: https://www.forecastinternational.com/archive/disp_old_pdf.cfm?ARC_ID=329

Maximum Range: Source: http://www.flugzeuginfo.net/acdata_php/acdata_emb120_en.php

First Flight: Source: http://www.flugzeuginfo.net/acdata_php/acdata_emb120_en.php

Aircraft Model: EMBRAER

Aircraft Version: ERJ145LR

Seats: Source: http://www.embraercommercialaviation.com/AircraftPDF/E145_Cabin.pdf

Fuel Capacity: Maximum useable fuel.

Source: http://www.embraercommercialaviation.com/AircraftPDF/E145_Weights.pdf

Maximum Range: Assuming a maximum landing weight.

Source: http://www.embraercommercialaviation.com/AircraftPDF/E145_Performance.pdf

First Flight: Source: http://www.aerospace-technology.com/projects/erj145/

Aircraft Model: EMBRAER

Aircraft Version: ERJ145LU

Seats:

Fuel Capacity: Source: https://en.wikipedia.org/wiki/Embraer_ERJ_145_family

Maximum Range:

First Flight:

Aircraft Model: EMBRAER

Aircraft Version: ERJ145LI

Seats:

Fuel Capacity:

Maximum Range:

First Flight:

Aircraft Model: EMBRAER

Aircraft Version: ERJ145EP

Seats:

Fuel Capacity: Source: https://en.wikipedia.org/wiki/Embraer_ERJ_145_family

Maximum Range:

First Flight:

Aircraft Model: EMBARER

Aircraft Version: ERJ145ER

Seats:

Fuel Capacity: Source: https://en.wikipedia.org/wiki/Embraer_ERJ_145_family

Maximum Range: Range with 50 passengers at long-range cruising speed.

Source: http://www.airliners.net/aircraft-data/embraer-erj-145/198

First Flight: 
Aircraft Model: EMBRAER

Aircraft Version: ERJ145EU

Seats:

Fuel Capacity:

Maximum Range:

First Flight:

Aircraft Model: EMBRAER

Aircraft Version: ERJ145MP

Seats:

Fuel Capacity:

Maximum Range: Source:

http://www.embraercommercialaviation.com/AircraftPDF/E145_Performance.pdf

First Flight:

Aircraft Model: EMBRAER

Aircraft Version: ERJ145XR

Seats: Source: http://www.embraercommercialaviation.com/Pages/ERJ-145XR.aspx

Fuel Capacity:

Maximum Range: Source:

http://www.embraercommercialaviation.com/AircraftPDF/E145XR_Performance.pdf

First Flight: Source: http://www.airliners.net/aircraft-data/embraer-erj-145/198

Aircraft Model: EMBRAER

Aircraft Version: ERJ135LR

Seats: Source: http://www.embraercommercialaviation.com/AircraftPDF/E145XR_Performance.pdf

Fuel Capacity: Standard fuel capacity.

Source: https://www.airlines-inform.com/commercial-aircraft/Embraer-ERJ-135.html

Maximum Range: Assuming full-load of passengers. Source:

http://www.embraercommercialaviation.com/AircraftPDF/E135_Performance.pdf

First Flight: Source: https://www.airlines-inform.com/commercial-aircraft/Embraer-ERJ-135.html

Aircraft Model: EMBRAER

Aircraft Version: ERJ135ER

Seats: Source: http://www.aerospace-technology.com/projects/erj-135/

Fuel Capacity: The original data was 4173 , but that was measurement was in $\mathrm{kg}$. We converted this number to litres assuming a volume mass of $.782 \mathrm{~kg} / \mathrm{L}$ (number given in EASA, 2016).

Source: http://www.aerospace-technology.com/projects/erj-135/

Maximum Range: Assuming a full-load of passengers.

Source: http://www.embraercommercialaviation.com/AircraftPDF/E135_Performance.pdf

First Flight: Source: http://www.aerospace-technology.com/projects/erj-135/

Aircraft Model: EMBRAER

Aircraft Version: ERJ140LR

Seats: Source: http://www.embraercommercialaviation.com/AircraftPDF/E140_Cabin.pdf

Fuel Capacity: Standard fuel capacity.

Source: https://www.airlines-inform.com/commercial-aircraft/Embraer-ERJ-140.html

Maximum Range: Assuming full-load of passengers.

Source: http://www.embraercommercialaviation.com/AircraftPDF/E140_Performance.pdf"

First Flight: Source: https://www.airlines-inform.com/commercial-aircraft/Embraer-ERJ-140.html

Aircraft Model: EMBRAER

Aircraft Version: ERJ170ST

Seats: Average between high-capacity single-class and dual-class.

Source: http://www.embraercommercialaviation.com/AircraftPDF/E170_Cabin.pdf 
Fuel Capacity: Maximum usable fuel. Source:

http://www.embraercommercialaviation.com/AircraftPDF/E170_Weights.pdf

Maximum Range: Assuming full-load of passengers, long-range cruise speed, and typical mission reserves. Source: http://www.embraercommercialaviation.com/AircraftPDF/E170_Performance.pdf First Flight: Source: https://www.airlines-inform.com/commercial-aircraft/Embraer-170.html

Aircraft Model: EMBRAER

Aircraft Version: ERJ170LR

Seats: Average between high-capacity single-class and dual-class.

Source: http://www.embraercommercialaviation.com/AircraftPDF/E170_Cabin.pdf

Fuel Capacity: Maximum usable fuel.

Source: http://www.embraercommercialaviation.com/AircraftPDF/E170_Weights.pdf

Maximum Range: Assuming full-load of passengers, long-range cruise speed, and typical mission reserves. Source: http://www.embraercommercialaviation.com/AircraftPDF/E170_Performance.pdf First Flight:

\section{Aircraft Model: EMBRAER}

Aircraft Version: ERJ170AR

Seats: Average between high-capacity single-class and dual-class.

Source: http://www.embraercommercialaviation.com/AircraftPDF/E170_Cabin.pdf

Fuel Capacity: Maximum usable fuel.

Source: http://www.embraercommercialaviation.com/AircraftPDF/E170_Weights.pdf

Maximum Range: Assuming full-load of passengers, long-range cruise speed, and typical mission reserves. Source: http://www.embraercommercialaviation.com/AircraftPDF/E170_Performance.pdf First Flight:

\section{Aircraft Model: EMBRAER \\ Aircraft Version: E175ST}

Seats: Average between high-capacity single-class and dual-class.

Source: http://www.embraercommercialaviation.com/AircraftPDF/E175_Cabin.pdf

Fuel Capacity: Maximum usable fuel.

Source: http://www.embraercommercialaviation.com/AircraftPDF/E175_Performance.pdf

Maximum Range: Assuming full-load of passengers, long-range cruise speed, and typical mission reserves. Source: http://www.embraercommercialaviation.com/AircraftPDF/E175_Performance.pdf First Flight: Source: http://www.airliners.net/aircraft-data/embraer-erj-170175190195/406

Aircraft Model: EMBRAER

Aircraft Version: E175LR

Seats: Average between high-capacity single-class and dual-class.

Source: http://www.embraercommercialaviation.com/AircraftPDF/E175_Cabin.pdf

Fuel Capacity: Maximum usable fuel.

Source: http://www.embraercommercialaviation.com/AircraftPDF/E175_Performance.pdf

Maximum Range: Assuming full-load of passengers, long-range cruise speed, and typical mission reserves. Source: http://www.embraercommercialaviation.com/AircraftPDF/E175_Performance.pdf First Flight:

Aircraft Model: EMBRAER

Aircraft Version: E190ST

Seats: Average between high-capacity single-class and dual-class.

Source: http://www.embraercommercialaviation.com/AircraftPDF/E190_Cabin.pdf

Fuel Capacity: Maximum usable fuel.

Source: http://www.embraercommercialaviation.com/AircraftPDF/E190_Weights.pdf

Maximum Range:

Assuming full-load of passengers, long-range cruise speed, and typical mission reserves. 
Source: http://www.embraercommercialaviation.com/AircraftPDF/E190_Performance.pdf

First Flight: Source: http://www.airliners.net/aircraft-data/embraer-erj-170175190195/406

\section{Aircraft Model: EMBRAER \\ Aircraft Version: E190LR}

Seats: Average between high-capacity single-class and dual-class.

Source: http://www.embraercommercialaviation.com/AircraftPDF/E190_Cabin.pdf

Fuel Capacity: Maximum usable fuel.

Source: http://www.embraercommercialaviation.com/AircraftPDF/E190_Weights.pdf

Maximum Range: Assuming full-load of passengers, long-range cruise speed, and typical mission reserves. Source: http://www.embraercommercialaviation.com/AircraftPDF/E190_Performance.pdf

First Flight:

Aircraft Model: EMBRAER

Aircraft Version: E190AR

Seats: Average between high-capacity single-class and dual-class.

Source: http://www.embraercommercialaviation.com/AircraftPDF/E190_Cabin.pdf

Fuel Capacity: Maximum usable fuel.

Source: http://www.embraercommercialaviation.com/AircraftPDF/E190_Weights.pdf

Maximum Range: Assuming full-load of passengers, long-range cruise speed, and typical mission reserves. Source: http://www.embraercommercialaviation.com/AircraftPDF/E190_Performance.pdf First Flight:

Aircraft Model: EMBRAER

Aircraft Version: E195ST

Seats: Average between high-capacity single-class and dual-class.

Source: http://www.embraercommercialaviation.com/AircraftPDF/E195_Cabin.pdf

Fuel Capacity: Maximum usable fuel.

Source: http://www.embraercommercialaviation.com/AircraftPDF/E195_Weights.pdf

Maximum Range: Assuming full-load of passengers, long-range cruise speed, and typical mission reserves. Source: http://www.embraercommercialaviation.com/AircraftPDF/E195_Performance.pdf First Flight: Source: http://www.airliners.net/aircraft-data/embraer-erj-170175190195/406

Aircraft Model: EMBRAER

Aircraft Version: E195LR

Seats: Average between high-capacity single-class and dual-class.

Source: http://www.embraercommercialaviation.com/AircraftPDF/E195_Cabin.pdf

Fuel Capacity: Maximum usable fuel.

Source: http://www.embraercommercialaviation.com/AircraftPDF/E195_Weights.pdf

Maximum Range: Assuming full-load of passengers, long-range cruise speed, and typical mission reserves. Source: http://www.embraercommercialaviation.com/AircraftPDF/E195_Performance.pdf First Flight:

\section{Aircraft Model: EMBRAER}

Aircraft Version: E195AR

Seats: Average between high-capacity single-class and dual-class.

Source: http://www.embraercommercialaviation.com/AircraftPDF/E195_Cabin.pdf

Fuel Capacity: Maximum usable fuel.

Source: http://www.embraercommercialaviation.com/AircraftPDF/E195_Weights.pdf

Maximum Range: Assuming full-load of passengers, long-range cruise speed, and typical mission reserves. Source: http://www.embraercommercialaviation.com/AircraftPDF/E195_Performance.pdf

First Flight:

Aircraft Model: FAIRCHILD

Aircraft Version: METRO/MERLIN 
Seats: Source: https://www.airlines-inform.com/commercial-aircraft/Fairchild-Metro.html

Fuel Capacity: Standard fuel capacity.

Source: https://www.airlines-inform.com/commercial-aircraft/Fairchild-Metro.html

Maximum Range: Assuming maximum payload.

Source: https://www.airlines-inform.com/commercial-aircraft/Fairchild-Metro.html

First Flight: Source: https://www.airlines-inform.com/commercial-aircraft/Fairchild-Metro.html

\section{Aircraft Model: FOKKER}

Aircraft Version: F100

Seats: Typical seating capacity.

Source: http://www.flugzeuginfo.net/acdata_php/acdata_fokker100_en.php

Fuel Capacity: Standard fuel capacity.

Source: https://www.airlines-inform.com/commercial-aircraft/Fokker-100.html

Maximum Range: Assuming maximum payload.

Source: https://www.airlines-inform.com/commercial-aircraft/Fokker-100.html

First Flight: Source: https://www.airlines-inform.com/commercial-aircraft/Fokker-100.html

Aircraft Model: FOKKER

Aircraft Version: F27 FRIENDSHIP

Seats: Maximum single-class. Source: http://www.mutleyshangar.com/reviews/ag/f27/f27.htm

Fuel Capacity: Maximum capacity. Source: http://www.mutleyshangar.com/reviews/ag/f27/f27.htm

Maximum Range: Assuming a full fuel-load and maximum take-off weight. Source:

http://www.mutleyshangar.com/reviews/ag/f27/f27.htm

First Flight: Source: http://www.airliners.net/aircraft-data/fokker-f-27-fairchild-f-27-fh-227/217

Aircraft Model: FOKKER

Aircraft Version: F28 FELLOWSHIP (MK3000)

Seats: Maximum. Source: http://www.airliners.net/aircraft-data/fokker-f-28-fellowship/219

Fuel Capacity:

Maximum Range: Average between high-speed cruise and long-range cruise, both with maximum seating capacity. Source: http://www.airliners.net/aircraft-data/fokker-f-28-fellowship/219

First Flight: Source: http://www.airliners.net/aircraft-data/fokker-f-28-fellowship/219

Aircraft Model: FOKKER

Aircraft Version: 50HP

Seats: Maximum single-class.

Source: https://www.airlines-inform.com/commercial-aircraft/Fokker-50.html

Fuel Capacity: Standard fuel capacity.

Source: https://www.airlines-inform.com/commercial-aircraft/Fokker-50.html

Maximum Range: Assuming maximum payload.

Source: https://www.airlines-inform.com/commercial-aircraft/Fokker-50.html

First Flight: Source: https://www.airlines-inform.com/commercial-aircraft/Fokker-50.html

Aircraft Model: FOKKER

Aircraft Version: 70

Seats: Maximum single-class

Source: https://www.airlines-inform.com/commercial-aircraft/Fokker-70.html

Fuel Capacity: Standard fuel capacity.

Source: https://www.airlines-inform.com/commercial-aircraft/Fokker-70.html

Maximum Range: Assuming maximum payload.

Source: https://www.airlines-inform.com/commercial-aircraft/Fokker-70.html

First Flight: Source: https://www.airlines-inform.com/commercial-aircraft/Fokker-70.html

Aircraft Model: ILYUSHIN

Aircraft Version: IL114 
Seats: Maximum single-class.

Source: https://www.airlines-inform.com/commercial-aircraft/Il-114.html

Fuel Capacity: Standard fuel capacity.

Source: https://www.airlines-inform.com/commercial-aircraft/Il-114.html

Maximum Range: Assuming maximum payload.

Source: https://www.airlines-inform.com/commercial-aircraft/Il-114.html

First Flight: Source: https://www.airlines-inform.com/commercial-aircraft/ll-114.html

Aircraft Model: ILYUSHIN

Aircraft Version: IL62

Seats: Average between single-class and dual-class seating capacity.

Source: https://www.airlines-inform.com/commercial-aircraft/Il-62.html

Fuel Capacity: Standard fuel capacity for IL62M.

Source: https://www.airlines-inform.com/commercial-aircraft/ll-62.html

Maximum Range: Assuming maximum payload.

Source: https://www.airlines-inform.com/commercial-aircraft/ll-62.html

First Flight: Source: https://www.airlines-inform.com/commercial-aircraft/ll-62.html

\section{Aircraft Model: ILYUSHIN}

Aircraft Version: IL18D

Seats: Maximum single-class capacity.

Source: https://www.airlines-inform.com/commercial-aircraft/Il-18.html

Fuel Capacity: Standard fuel capacity.

Source: https://www.airlines-inform.com/commercial-aircraft/Il-18.html

Maximum Range: Assuming maximum payload.

Source: https://www.airlines-inform.com/commercial-aircraft/ll-18.html

First Flight: Source: http://www.airliners.net/aircraft-data/ilyushin-il-18/249

\section{Aircraft Model: ILYUSHIN}

Aircraft Version: IL96-300

We chose the non-stretched version (-400 being the stretched version).

Seats: Average between single-class and three-class seating capacity.

Source: https://www.airlines-inform.com/commercial-aircraft/ll-96.html

Fuel Capacity: Standard fuel capacity.

Source: https://www.airlines-inform.com/commercial-aircraft/Il-96.html

Maximum Range: Assuming maximum payload.

Source: https://www.airlines-inform.com/commercial-aircraft/ll-96.html

First Flight: Source: https://www.airlines-inform.com/commercial-aircraft/Il-96.html

\section{Aircraft Model: INDONESIAN AEROSPACE \\ Aircraft Version: C-212-400 AVIOCR}

Seats: Average between given range: seating information not given.

Source: https://www.indonesian-aerospace.com/view.php?m=product\&t=aircraft-detil\&id=1

Fuel Capacity: Standard fuel capacity.

Source: https://www.airlines-inform.com/commercial-aircraft/CASA-212.html

Maximum Range: Assuming maximum payload.

Source: https://www.airlines-inform.com/commercial-aircraft/CASA-212.html

First Flight: Source: https://www.airlines-inform.com/commercial-aircraft/CASA-212.html

Aircraft Model: LET

Aircraft Version: L-410-UVP-E20

Seats: Maximum single-class.

Source: https://www.airlines-inform.com/commercial-aircraft/L-410.html

Fuel Capacity: Standard fuel capacity.

Source: https://www.airlines-inform.com/commercial-aircraft/L-410.html 
Maximum Range: Assuming maximum payload.

Source: https://www.airlines-inform.com/commercial-aircraft/L-410.html

First Flight: Source: https://www.airlines-inform.com/commercial-aircraft/L-410.html

\section{Aircraft Model: MCDONNELL DOUGLAS}

Aircraft Version: DC-10CF

Seats: Average between maximum and standard seating capacity. Source:

$\mathrm{http}: / /$ www.boeing.com/resources/boeingdotcom/company/about_bca/startup/pdf/historical/dc10passenger.pdf

Fuel Capacity: Usable fuel capacity. Source:

http://www.boeing.com/resources/boeingdotcom/company/about_bca/startup/pdf/historical/dc10passenger.pdf

Maximum Range: Assuming maximum payload.

Source: http://www.boeing.com/commercial/aeromagazine/aero_02/textonly/ps02txt.html

First Flight: Source: http://www.airliners.net/aircraft-data/mcdonnell-douglas-dc-10-boeing-md$10 / 279$

\section{Aircraft Model: MCDONNELLL DOUGLAS}

Aircraft Version: DC8-43

Seats: Maximum seating capacity (class not specified).

Source: http://www.boeing.com/assets/pdf/commercial/airports/acaps/dc8.pdf

Fuel Capacity: Usable fuel.

Source: http://www.boeing.com/assets/pdf/commercial/airports/acaps/dc8.pdf

Maximum Range: Source: http://www.boeing.com/news/frontiers/archive/2008/june/i_history.pdf

First Flight: Source: http://www.boeing.com/history/products/dc-8.page

\section{Aircraft Model: MCDONNEL DOUGLAS}

Aircraft Version: DC9-30

Seats: Average between single-class and three-class seating capacity.

Source: https://www.airlines-inform.com/commercial-aircraft/Douglas-DC-9.html

Fuel Capacity: Standard fuel capacity.

Source: https://www.airlines-inform.com/commercial-aircraft/Douglas-DC-9.html

Maximum Range: Assuming maximum payload.

Source: https://www.airlines-inform.com/commercial-aircraft/Douglas-DC-9.html

First Flight: Source: https://www.airlines-inform.com/commercial-aircraft/Douglas-DC-9.html

\section{Aircraft Model: MCDONNEL DOUGLAS}

Aircraft Version: DC9-10

Seats: Single-class seating capacity.

Source: http://www.airliners.net/aircraft-data/mcdonnell-douglas-dc-9-102030/276

Fuel Capacity: Source: http://planes.axlegeeks.com/l/461/McDonnell-Douglas-DC-9-10

Maximum Range: Assuming maximum payload.

Source: http://www.airliners.net/aircraft-data/mcdonnell-douglas-dc-9-102030/276

First Flight: Source: http://www.airliners.net/aircraft-data/mcdonnell-douglas-dc-9-102030/276

\section{Aircraft Model: MCDONNELL DOUGLAS \\ Aircraft Version: DC9-50}

Seats: Average between single-class and coach-class seating capacity. Source:

http://www.boeing.com/resources/boeingdotcom/company/about_bca/startup/pdf/historical/dc9passenger.pdf

Fuel Capacity: Standard fuel capacity.

Source: https://www.airlines-inform.com/commercial-aircraft/Douglas-DC-9.html

Maximum Range: Assuming maximum payload.

Source: https://www.airlines-inform.com/commercial-aircraft/Douglas-DC-9.html

First Flight: Source: http://www.boeing.com/history/products/dc-9.page 
Aircraft Model: NAMC

Aircraft Version: YS11A-200

Seats: Single-class seating capacity.

Sources: http://www.airliners.net/aircraft-data/namc-ys-11/287

Fuel Capacity: Source: http://www.airvectors.net/avnamc.html

Maximum Range: Assuming maximum payload.

Source: https://www.airlines-inform.com/commercial-aircraft/YS-11.html

First Flight: Source: http://www.worldlibrary.org/articles/namc_ys-11a

Aircraft Model: SAAB

Aircraft Version: 2000

Seats: Maximum single-class capacity.

Source: https://www.airlines-inform.com/commercial-aircraft/SAAB-2000.html

Fuel Capacity: Standard fuel capacity.

Source: https://www.airlines-inform.com/commercial-aircraft/SAAB-2000.html

Maximum Range: Assuming maximum payload.

Source: https://www.airlines-inform.com/commercial-aircraft/SAAB-2000.html

First Flight: Source: https://www.airlines-inform.com/commercial-aircraft/SAAB-2000.html

Aircraft Model: SAAB

Aircraft Version: 340B PLUS

Seats: Maximum single-class capacity.

Source: https://www.airlines-inform.com/commercial-aircraft/SAAB-340.html

Fuel Capacity: Standard fuel capacity.

Source: https://www.airlines-inform.com/commercial-aircraft/SAAB-340.html

Maximum Range: Assuming maximum payload.

Source: https://www.airlines-inform.com/commercial-aircraft/SAAB-340.html

First Flight: Source: https://www.airlines-inform.com/commercial-aircraft/SAAB-340.html

Aircraft Model: SHORTS

Aircraft Version: 330-200

Seats: Maximum single-class capacity.

Source: https://www.airlines-inform.com/commercial-aircraft/Shorts-330.html

Fuel Capacity: Standard fuel capacity.

Source: https://www.airlines-inform.com/commercial-aircraft/Shorts-330.html

Maximum Range: Assuming maximum payload.

Source: https://www.airlines-inform.com/commercial-aircraft/Shorts-330.html

First Flight: Source: https://www.airlines-inform.com/commercial-aircraft/Shorts-330.html

Aircraft Model: SHORTS

Aircraft Version: 360-300

Seats: Maximum single-class capacity.

Source: https://www.airlines-inform.com/commercial-aircraft/Shorts-360.html

Fuel Capacity: Standard fuel capacity.

Source: https://www.airlines-inform.com/commercial-aircraft/Shorts-360.html

Maximum Range: Assuming maximum payload.

Source: https://www.airlines-inform.com/commercial-aircraft/Shorts-360.html

First Flight: Source: https://www.airlines-inform.com/commercial-aircraft/Shorts-360.html

Aircraft Model: SUKHOI SUPERJET 100

Aircraft Version: SSJ-95

Seats: Average between maximum and dual-class seating capacity.

Source: http://www.airliners.net/aircraft-data/sukhoi-superjet-100/408

Fuel Capacity: Source: http://planes.axlegeeks.com/1/336/Sukhoi-Superjet-100-95 
Maximum Range: Assuming maximum payload.

Source: https://www.airlines-inform.com/commercial-aircraft/Superjet-100.html

First Flight: Source: https://www.airlines-inform.com/commercial-aircraft/Superjet-100.html

Aircraft Model: SUKHOI SUPERJET 100

Aircraft Version: SSJ-95LR

Seats: Average between maximum and dual-class seating capacity.

Source: http://www.airliners.net/aircraft-data/sukhoi-superjet-100/408

Fuel Capacity: Source: http://planes.axlegeeks.com/1/336/Sukhoi-Superjet-100-95

Maximum Range: Assuming maximum payload.

Source: https://www.airlines-inform.com/commercial-aircraft/Superjet-100.html

First Flight: Source: https://www.airlines-inform.com/commercial-aircraft/Superjet-100.html

Aircraft Model: TUPOLEV

Aircraft Version: TU134A

Seats: Average between single-class and dual-class seating capacity.

Source: https://www.airlines-inform.com/commercial-aircraft/Tu-134.html

Fuel Capacity: The original data was 14400, but that was measurement was in $\mathrm{kg}$. We converted this number to litres assuming a volume mass of .782 kg/L (number given in EASA, 2016).

Source: https://www.airlines-inform.com/commercial-aircraft/Tu-134.html

Maximum Range: Assuming maximum payload.

Source: https://www.airlines-inform.com/commercial-aircraft/Tu-134.html

First Flight: Source: https://www.airlines-inform.com/commercial-aircraft/Tu-134.htm\

\section{Aircraft Model: TUPOLEV}

Aircraft Version: TU154

Seats: Average between maximum single-class and minimum dual-class seating capacity.

Source: https://www.airlines-inform.com/commercial-aircraft/Tu-154.html

Fuel Capacity: Source: https://en.wikipedia.org/wiki/Tupolev_Tu-154

Maximum Range: Assuming maximum payload.

Source: https://www.airlines-inform.com/commercial-aircraft/Tu-154.html

First Flight: Source: https://www.airlines-inform.com/commercial-aircraft/Tu-154.html

\section{Aircraft Model: TUPOLEV}

Aircraft Version: TU204-100

Seats: Average between single-class and three-class seating capacity.

Source: https://www.airlines-inform.com/commercial-aircraft/Tu-204-100.html

Fuel Capacity: Standard fuel capacity.

Source: https://www.airlines-inform.com/commercial-aircraft/Tu-204-100.html

Maximum Range: Assuming maximum payload.

Source: https://www.airlines-inform.com/commercial-aircraft/Tu-204-100.html

First Flight: Source: https://www.airlines-inform.com/commercial-aircraft/Tu-204-family.html

\section{Aircraft Model: XIAN}

Aircraft Version: MA60

Seats: Single-class seating capacity.

Source: http://www.flugzeuginfo.net/acdata_php/acdata_xian_ma60_en.php

Fuel Capacity: The original data was 4030, but that was measurement was in $\mathrm{kg}$. We converted this number to litres assuming a volume mass of .782 kg/L (number given in EASA, 2016).

Source: https://www.airlines-inform.com/commercial-aircraft/Xian-MA60.html

Maximum Range: Assuming maximum payload.

Source: https://www.airlines-inform.com/commercial-aircraft/Xian-MA60.html

First Flight: Source: http://www.flugzeuginfo.net/acdata_php/acdata_xian_ma60_en.php 
Aircraft Version: YAK40

Seats: Average between single-class variations.

Source: https://www.airlines-inform.com/commercial-aircraft/Yak-40.html

Fuel Capacity: The original data was 4430, but that was measurement was in $\mathrm{kg}$. We converted this number to litres assuming a volume mass of .782 $\mathrm{kg} / \mathrm{L}$ (number given in EASA, 2016).

Source: https://www.airlines-inform.com/commercial-aircraft/Yak-40.html

Maximum Range: Assuming maximum payload.

Source: https://www.airlines-inform.com/commercial-aircraft/Yak-40.html

First Flight: Source: https://www.airlines-inform.com/commercial-aircraft/Yak-40.html

Aircraft Model: YAKOVLEV

Aircraft Version: YAK42D

Seats: Class that each seating capacity refers to was not specified.

Source: https://www.forecastinternational.com/archive/disp_old_pdf.cfm?ARC_ID=1055

Fuel Capacity: Maximum capacity.

Source: https://www.forecastinternational.com/archive/disp_old_pdf.cfm?ARC_ID=1055

Maximum Range: Assuming normal payload.

Source: https://www.forecastinternational.com/archive/disp_old_pdf.cfm?ARC_ID=1055

First Flight:

Source: https://www.forecastinternational.com/archive/disp_old_pdf.cfm?ARC_ID=1055

Reference:

EASA (2016). EASA, TYPE-CERTIFICATE DATA SHEET: AIRBUS A300, A310 and A300-600, TCDS No. A172, Issue02, 24 November 2016.

Airbus Family booklet (2016).

http://www.aircraft.airbus.com/fileadmin/media_gallery/files/brochures_publications/aircraft_families /Airbus-Family-figures-booklet-March2016.pdf 